UNIVERSIDADE DE SÃO PAULO

FFCLRP -Departamento de Psicologia e Educação

Programa de Pós-Graduação em PSICOBIOLOGIA

\title{
Modelação do processamento neuronal primário no sistema visual de mamíferos.
}

\author{
Rodrigo Freire Oliveira
}

Dissertação de Mestrado apresentada à Faculdade de Filosofia Ciências e Letras de Ribeirão Preto, como parte das exigências para a obtenção do título de MESTRE EM CIÊNCIAS.

Área: PSICOBIOLOGIA.

Ribeirão Preto - SP

2001 
UNIVERSIDADE DE SÃO PAULO

FFCLRP -Departamento de Psicologia e Educação

Programa de Pós-Graduação em PSICOBIOLOGIA

\section{Modelação do processamento neuronal primário no sistema visual de mamíferos.}

Dissertação de Mestrado apresentada à Faculdade de Filosofia Ciências e Letras de Ribeirão Preto, como parte das exigências para a obtenção do título de MESTRE EM CIÊNCIAS.

Área: PSICOBIOLOGIA.

Aluno: Rodrigo Freire Oliveira

Orientador: Prof. Dr. Antônio Carlos Roque da Silva Filho

Ribeirão Preto - SP

2001 
"O olho a si mesmo não enxerga, senão pelo reflexo em outra coisa" William Shakspeare, Júlio César (Ato I - Cena II: Bruto) 


\section{Índice.}

Agradecimentos iii

Lista de Figuras. iv

Lista de Tabelas. ix

ABSTRACT $\mathrm{X}$

SUMÁRIO xi

\section{CAPÍTULO I}

Introdução.

\section{CAPÍTULO II}

Revisão. 6

Neurônios. 6

Estruturas.

Mapas Corticais e Sistemas Colunares. 9

\section{CAPÍTULO III}

O Modelo. 22

Neurônios.

Estruturas.

\section{CAPÍTULO IV}

Resultados.

Neurônios.

Estruturas.

Protocolo I - Ocularidade.

Protocolo II - Orientação.

\section{CAPÍTULO V}

Discussão e Conclusão. 53

Principais Aproximações. 53

Ocularidade.

Orientação. 55

Comentários Finais. 
Oliveira, Rodrigo Freire

Modelação do processamento neuronal primário no sistema visual de mamíferos.

Ribeirão Preto, 2001.

90 p. : il. ; $31 \mathrm{~cm}$.

Dissertação de Mestrado apresentada à Faculdade de Filosofia Ciências e Letras de Ribeirão Preto/USP - Dept ${ }^{\circ}$ de Psicologia e Educação.

Orientador: Antonio Carlos Roque da Silva Filho

1. Redes Neurais. 2. Modelação computacional. 3. Sistema visual 


\section{Agradecimentos.}

Agradeço,

Aos meus pais, Abelardo e Lucy, por terem me ensinado a ter caráter, e amor pelo trabalho. Obrigado por terem confiado em mim sempre. Mesmo quando a minha própria confiança esteve abalada.

Ao meu orientador Antonio Carlos Roque, pelo apoio fenomenal, pelo entusiasmo constante e pela amizade sincera.

Às minhas tias Laurinha e Lucila pela preocupação e por terem aturado os "pitis" de minha mãe quando ela achava que eu havia sido abduzido por extraterrestres ou sequestrado por ladrões de orgãos ou qualquer outra coisa que a imaginação fenomenal dela fosse capaz de inventar, caso ela não me encontrasse em casa. Obrigado. Vocês são umas santas.

Aos meus amigos pelo apoio e pelo carinho, mesmo à distância. Especialmente, Janaína "Palito-depicolé-capelinha" Sampaio Arnold, Marcelo Fagundes "Ô Cebolão" Sangiovanni, Gustavo "Pitú" Aguiar Monteiro, Leonardo "Maga" Magno Magalhães, Edwaldo "Waldo" Bispo Gomes Filho, Ana Paula "Ninha" Lima, Camila "Cami Ho!" Valverde Santana, Ceiçinha "Batatas", Tissiana "Saco-deosso" Berenguer Cavalcante, Pe. Domingos Sávio, Ana Paula Pereira Gomes, Jorgilene Lima, Paola.

Aos meus professores de graduação em psicologia na UFBa, pelo incentivo. Especialmente, Profa. Dra. Eulina da Rocha "Chefe/Yoda" Lordelo, Prof. Dr. Pedro Agostinho, Profa. Dra. Anamélia "Dra. Mel" Lins. Obrigado por terem confiado em mim e me ensinado a respeitar o meu trabalho. A minha querida Yoda, um agradecimento especial por me ensinar os fundamentos da estatística e da culinária, ao mesmo tempo.

Aos novos amigos que fiz em Ribeirão Preto. Especialmente, Renata Beatriz Vicentini por ser uma amiga muito especial que, como já disse alguém, é capaz de alegrar qualquer ambiente. A Juliana Setem "feito o quê?" Carvalho, por ser uma grande amiga e por emprestar o ouvido pra me escutar toda vez que a barra pesava. Ao Daniel "Do Daniel" Machado Luiz Vianna por ter dividido comigo o seu ótimo gosto pela música, literatura e artes em geral. Ao Silvio Morato por ter me ensinado a dançar tango e ter me apresentado os benefícios do álcool. Minhas bochechas sinceramente dormentes agradecem.

A Adail, Luís, Sara, Pri e Shirley que me receberam em sua casa nos primeiros meses que passei em Ribeirão Preto e se tornaram uma extensão de minha família.

\section{À Fundação de Amparo à pesquisa do estado de São Paulo - FAPESP pelo suporte financeiro que permitiu a realização deste trabalho.}




\section{Lista de Figuras.}

Figura 1. Os dois primeiros gráficos apresentam (da esquerda para a direita) as melhores aproximações para as funções de magnificação (células/grau2) para os canais M e P do NGL de primatas, respectivamente, em escala semi-logarítmica. O primeiro gráfico da segunda linha corresponde a soma das funções dos dois primeiros gráficos da primeira linha acrescidos de $10 \%$, em escala semi-logarítmica. A superposição da densidade de células ganglionares da retina (WÄSSLE et al., 1990) sobre a função de magnificação mostrou boa concordância. O último gráfico descreve a relação entre a densidade de células no canal $\mathrm{M}$ e a densidade de células no canal $\mathrm{P}$ do NGL em função da excentricidade. Todos os dados apresentados em traço espesso foram obtidos utilizando as equações apresentadas em MALPELI et al. (1996) e as curvas apresentadas em traço vermelho foram retiradas de SCHEIN \& MONASTERIO (1987).

Figura 2. As curvas apresentadas no primeiro gráfico são as melhores aproximações para as funções de magnificação cortical areal apresentadas na literatura em escala logarítmica. Em vermelho (TOOTELL et al., 1988), em azul (VAN ESSEN et al., 1984), e em laranja, (HUBEL \& FREEMAN, 1977). Em preto, o traço mais espesso corresponde à média dos demais estudos calculada por MALPELI et al. (1996). No segundo gráfico estão apresentadas as curvas que descrevem a densidade aferente para o canal M. Em vermelho (SCHEIN \& MONASTERIO, 1987), em preto, o traço mais espesso, (MALPELI et al., 1996).

Figura 3. Os campos receptivos concêntricos das células ganglionares contrastam com os campos receptivos seletivos à orientação das células simples do córtex visual. Adaptado de (WEHMEIER, et al., 1989)

Figura 4. Representação esquemática do neurônio de relê talâmico do NGL desenvolvido neste trabalho. A distribuição dos canais iônicos e sinápticos está ilustrada na figura.

Figura 5. Representação esquemática da célula estrelada da camada 4 do cortex de mamíferos desenvolvida neste trabalho. A distribuição dos canais iônicos e sinápticos está ilustrada na figura.

Figura 6. Representação esquemática do interneurônio GABAérgico (célula em cesto) da camada 4 do cortex de mamíferos desenvolvida neste trabalho. A distribuição dos canais iônicos e sinápticos está ilustrada na figura.

Figura 7. Representação esquemática do padrão de conexão entre o NGL e camada 4C $\alpha$ no modelo. À esquerda estão representadas as lâminas do NGL (1 e 2) e à direita uma área da camada 4C $\alpha$. No NGL M1 e M2 duas células estão destacadas em tonalidades diferentes e no córtex, na camada 4C $\alpha$, as áreas cobertas por seus terminais axonais estão também destacadas com as mesmas tonalidades. É possível observar que há uma diminuição na ocorrência de conexões nas margens destas áreas._32

Figura 8. Representação esquemática do padrão de conexão intralaminar na camada $4 \mathrm{C} \alpha$ no modelo. A) As células estreladas conectam-se com as células estreladas $(e \rightarrow$ e) em uma região circular próxima com raio igual $0,1 \mathrm{~mm}$. B) As células estreladas conectam-se com as células em cesto $(\mathrm{e} \rightarrow \mathrm{i})$ em um anel cujo raio interno mede $0,15 \mathrm{~mm}$ e o raio externo mede $0,25 \mathrm{~mm}$. C) As células em cesto conectam-se com as células estreladas $(\mathrm{i} \rightarrow \mathrm{e})$ em um anel cujo raio interno mede $0,1 \mathrm{~mm}$ e o raio externo mede $0,3 \mathrm{~mm}$. Em todos os casos está apresentada apenas uma pequena 
área das camadas. Além disso, esta representação não obedece ao escalonamento apresentado discutido nesta sessão.

Figura 9. Representação esquemática do padrão de conexão interlaminar entre a camada $4 \mathrm{C} \alpha$ e a camada 4B no modelo. Há três áreas destacadas na camada 4B. Uma destas áreas é composta por neurônios que respondem a estímulos com 450 de orientação. Nesta região, há dois neurônios destacados. Os neurônios que os inervam presentes na camada $4 \mathrm{C} \alpha$ também estão destacados com a mesmas tonalidades. O Padrão de conexão mantém-se topográfico. As áreas adjacentes, na camada 4B são compostas por neurônios que respondem seletivamente a orientações diferentes mas próximas de 450 .

Figura 10. Representação esquemática do padrão de conexão entre as estruturas no modelo. As retinas estão apresentadas compostas por objetos capazes de gerar disparos de acordo com o método descrito no apêndice II. Estão conectadas com o NGL de forma topográfica com uma relação 1:1. Tanto a retina quanto o NGL estão representadas por matrizes com o mesmo dimensionamento do modelo. As demais estruturas estão representadas por áreas retangulares. A camada $4 \mathrm{C} \alpha$ recebe conexões do NGL de forma que as entradas originadas das áreas que representam o olho direito e o olho esquerdo permaneçam segregadas. Os terminais axonais têm forma elíptica e têm seu principal eixo paralelo às áreas monoculares desta camada. O padrão de conexão entre a camada $4 \mathrm{C} \alpha$ e a camada 4B foi organizado de forma topográfica e uma tendência a orientação foi estabelecida. Esta estratégia, entretanto, promoveu a existência de células cujos campos receptivos foram cortados devido à localização próxima da borda da matriz.

Figura 11. Padrão e disparo repetido da célula de relê talâmica. A frequência apresentada na primeira curva $\mathrm{f}-\mathrm{i}$ foi calculada utilizando-se o primeiro intervalo entre potenciais de ação (1/1oIPA). Ao primeiro gráfico foi acrescentada uma curva f-i retirada de uma investigação eletrofisiológica sobre as propriedades de neurônios de relê talâmicos (ZHAN et al., 1999). A frequência apresentada na segunda curva f-i corresponde a uma média dos últimos 0.5 seg de um total de 2 seg de estimulação. A curva IPAm-i apresenta a média dos IPAs para cada valor de corrente. $\mathrm{O}$ terceiro gráfico IPA-intervalo apresenta a variação dos IPAs por intervalo para 4 valores de corrente injetada. Não há evidência de adaptação para nenhum valor de corrente.

Figura 12. Resposta dos neurônios de relê talâmicos a diferentes valores de corrente. Os neurônios modelados foram submetidos ao seguinte padrão de estimulação: durante $0,1 \mathrm{seg}$ os neurônios não são submetidos a injeção de corrente, durante os 0,2 seg seguintes, o neurônio é submetido a uma injeção de corrente (os valores estão assinalados no alto de cada gráfico). Em seguida, a injeção de corrente é interrompida. Pode-se perceber que o neurônio possui um potencial e repouso estável e que mediante valores de injeção de corrente sucessivamente aumentados, sua frequência de disparo é também aumentada. Após cessada a estimulação o neurônio retorna ao seu potencial de repouso. No último gráfico ( $\mathrm{I}=1,95$ x 10-9 A), a injeção de corrente é interrompida no momento em que o neurônio está sendo repolarizado e ocorre a ativação do canal de cálcio de baixo limiar que leva a geração de um potencial de ação lento e em seu topo, um potencial de ação convencional.

Figura 13. Disparos em rajada na célula de relê talâmica. A variação do potencial de membrana apresentada nesta figura foi obtida mantendo-se o potencial de membrana estável e próximo a -0,06 V. e injetando valores de corrente hiperpolarizadoras. O gráfico apresenta a variação do potencial de membrana para uma injeção de corrente no valor -0,3 x 10-9 A. Pode-se perceber a ocorrência de diversos disparos em rajada. 
Figura 14. Padrão de disparo repetido da célula estrelada da camada 4. A frequência apresentada na primeira curva $\mathrm{f}-\mathrm{i}$ foi calculada através do primeiro intervalo entre potenciais de ação (1/1oIPA). A frequência apresentada na segunda curva f-i corresponde a média da duração dos intervalos entre potenciais de ação durante os últimos 0,5 seg de um total de 2 seg de estimulação. Comparando-se a primeira e a segunda curva pode-se perceber uma diferença marcante entre elas que se deve a adaptação flagrante presente nesta classe de neurônios. A curva IPAm-i apresenta a média dos IPAs para cada valor de corrente. O terceiro gráfico IPA-intervalo apresenta a variação dos IPAs por intervalo para 4 valores de corrente injectada. Foram acrescentadas ao primeiro gráfico duas curvas f-i (A e B) retiradas de McCORMICK et al. (1985) associadas a neurônios piramidais classificados como NDRes.

Figura 15. Resposta da célula estrelada da camada 4 a diferentes valores de corrente. Os neurônios modelados foram submetidos ao seguinte padrão de estimulação: durante 0,1 seg os neurônios não são submetidos a injeção de corrente, durante os 0,2 seg seguintes, o neurônio é submetido a uma injeção de corrente (os valores estão assinalados no alto de cada gráfico). Em seguida, a injeção de corrente é interrompida. Pode-se perceber que o neurônio possui um potencial e repouso estável e que mediante valores de injeção de corrente sucessivamente aumentados, sua frequência de disparo é também aumentada. Após cessada a estimulação o neurônio retorna ao seu potencial de repouso lentamente.

Figura 16. Padrão de disparo repetido da célula em cesto da camada 4. A frequência apresentada na primeira curva $\mathrm{f}-\mathrm{i}$ foi calculada através do primeiro intervalo entre potenciais de ação (1/1o IPA). A frequência apresentada na segunda curva f-i corresponde a média da duração dos intervalos entre potenciais de ação durante os últimos $0,5 \mathrm{seg}$ de um total de 2 seg de estimulação. A curva IPAm-i apresenta a média dos IPAs para cada valor de corrente. O terceiro gráfico IPA-intervalo apresenta a variação dos IPAs por intervalo para 4 valores de corrente injetada. A pequena seta neste gráfico chama a atenção para a pequena adaptação seguida por aceleração ambas características de interneurônios GABAérgicos de V1 (AZOUZ, et al., 1997). Ao primeiro gráfico foram acrescentadas curvas f-i retiradas da literatura (ERISIR et al., 1999) (A) e (McCORMICK et al., 1985) (B).

Figura 17. Resposta da célula célula em cesto a diferentes valores de corrente. Os neurônios modelados foram submetidos ao seguinte padrão de estimulação: durante 0,1 seg os neurônios não são submetidos a injeção de corrente, durante os 0,2 seg seguintes, o neurônio é submetido a uma injeção de corrente (os valores estão assinalados no alto de cada gráfico). Em seguida, a injeção de corrente é interrompida. Pode-se perceber que o neurônio possui um potencial e repouso estável e que mediante valores de injeção de corrente sucessivamente aumentados, sua frequência de disparo é também aumentada. Após cessada a estimulação o neurônio retorna ao seu potencial de repouso rapidamente.

Figura 18. Seletividade a ocularidade em neurônios da camada $4 \mathrm{C} \alpha$. Os neurônios foram submetidos ao protocolo descrito no texto e os valores médios de suas seletividades descritas em p.a./seg estão apresentadas nos gráficos de barras acima. As figuras 18 A-D mostram 4 células seletivas a estímulos do olho contralateral as figuras 18 E-H mostram 4 células seletivas a estímulos do olho ipsilateral.

Figura 19. Seletividade a ocularidade em neurônios da camada 4B. Os neurônios foram submetidos ao protocolo descrito no texto e os valores médios de seletividade descritos em p.a./seg estão apresentados nos gráficos de barras acima. As figuras 19 A e C mostram uma célula seletiva a estímulos do olho ipsilateral. As figuras 19 B e D mostram uma célula seletiva a estímulos do olho 
contralateral. A diferença entre os gráficos A-B e C-D está na escala utilizada. Os gráficos A-B usam a mesma escala utilizada na figura 18. É possível observar as diferenças de nível de atividade entre estas duas camadas.

Figura 20. Variação do potencial de membrana de um neurônio seletivo a estímulos com 45o de orientação quando submetido a estimulação com grade sinusoidal com esta orientação. Partindo do primeiro gráfico à esquerda no canto superior até o último à direita no canto inferior, a estimulação teve seu contraste variado de $20 \%$ até $80 \%$ em intervalos de $20 \%$. A duração da estimulação está marcada em cada gráfico por um traço $(0,1 \mathrm{seg}$ até $0,2 \mathrm{seg})$.

Figura 21. Variação do potencial de membrana de um neurônio seletivo a estímulos com 45o de orientação quando submetido a estimulação com grade sinusoidal com diversas orientações e contrastes. Para cada gráfico, há dois valores apresentados. O primeiro em negrito, corresponde ao contraste e o segundo, corresponde à orientação. Este protocolo foi repetido 10 vezes e o resultado em p.a./seg foi utilizado na construção das curvas de sintonia.

Figura 22. Curva de sintonia do neurônio cuja variação do potencial de membrana foi apresentada nas figuras 20 e 21 . Este neurônio é seletivo à estímulos com orientação igual a 450 . A seletividade mostrou-se estável, precisa e invariante à contraste. Os valores de contraste estão assinalados na legenda.

Figura 23. Este neurônio é seletivo à estímulos com orientação igual a 90o. Entretanto, sua seletividade é bem mais ampla do que a seletividade do neurônio apresentada na figura 22. Este neurônio responde a estímulos com orientações até 30o superiores ou inferiores a 90o. Os valores de contraste estão assinalados na legenda.

Figura 24. Este neurônio é seletivo à estímulos com orientação igual a 135o. Entretanto, sua seletividade não é invariante à contraste. Para valores de contraste iguais a $80 \%$, este neurônio mostrou-se seletivo à orientações $30 \mathrm{o}$ superiores e inferiores a $135 \mathrm{o}$. Os valores de contraste estão assinalados na legenda.

Figura 25. Modelos de seletividade à orientação no córtex visual. a) Modelo de Hubel e Wiesel propõe o alinhamento geométrico das entradas talâmicas como responsável pela seletividade à orientação. Neurônios corticais (triângulos = excitatórios; hexágonos = inibitórios) recebem as entradas talâmicas convergentes alinhadas. b) Inibição de orientações cruzadas. Muitos modelos inibitórios estabelecem uma fraca tendência de alinhamento das entradas do NGL que levaria a uma orientação inicial e utilizam um padrão de circuitaria intracortical inibitória (setas brancas) comprometida com orientações diferentes da célula alvo. Este padrão de circuito suprimiria respostas de neurônios seletivos à diferentes orientações. c) Excitação recorrente. Neste modelo, a excitação cortical entre células preferindo orientações similares combinada com fraca inibição de células de mesma orientação e de orientação diferente atua sobre uma fraca tendência de alinhamento das entradas do NGL gerando a seletividade à orientação. (Adaptado de (SOMERS et al. 1995)).

Figura 26. Variação da seletividade à orientação no córtex visual primário de primatas calculada em função do tempo através de correlação reversa. Os resultados foram calculados para neurônios das camadas 4C $\alpha$ e 4B (Adaptado de RINGACH et al., 1997).

Figura 27. A) Representação de uma área da membrana de neurônios com dois canais iônicos presentes. Pode-se observar as duas camadas de moléculas fosfolipídicas com suas extremidades 
polares voltadas para as faces interna e externa da membrana. B) Circuito elétrico associado. Este circuito consiste em um capacitor $\mathrm{C}$ e uma resistência $\mathrm{R}$ em série com uma bateria $\mathrm{Vm}$ (adaptado de $(\mathrm{KOCH}, 1998)$ ).

Figura 28. Circuito elétrico equivalente a um segmento de membrana da lula. Hdgkin e Huxley utilizaram este circuito composto por um capacitor $\mathrm{Cm}$, uma condutância de vazamento $\mathrm{Gm}=1 / \mathrm{Rm}$ e duas condutâncias dependentes da voltagem e do tempo para o sódio e o potássio em seu modelo para geração do potencial de ação (adaptado de (KOCH, 1998)).

Figura 29. Exemplo de grade sinusoidal com 450 de orientação. Este padrão de estimulação foi utilizado para investigar a seletividade de neurônios corticais à orientação. 71 


\section{Lista de Tabelas.}

Tab. 1. Dados básicos referentes ao padrão de entrada do canal M em V1; densidades totais de neurônios nas camadas 4C $\alpha$ e $(4 \mathrm{~B} 1+4 \mathrm{~B} 2)$; percentagens médias de neurônios GABAérgicos em V1. A última coluna da tabela contém as referências de onde foram coletados os valores.

Tab. 2. Parâmetros utilizados na construção dos neurônios de relê talâmicos do NGL. A última coluna da tabela contém as referências de onde foram coletados os valores.

Tab. 3. Parâmetros utilizados na construção das células estreladas da camada 4 do córtex visual. A última coluna da tabela contém as referências de onde foram coletados os valores.

Tab. 4. Parâmetros utilizados na construção dos interneurônios GABAérgicos do córtex visual. A última coluna da tabela contém as referências de onde foram coletados os valores.

Tab. 5. Célula de relê talâmica. Os parâmetros quantitativos referentes à forma do potencial de ação foram medidos submetendo-se o neurônio modelado a correntes exatamente iguais ao limiar de disparo de potenciais de ação por um período de $0,2 \mathrm{seg}$.

Tab. 6. Célula estrelada da camada 4. Os parâmetros quantitativos referentes à forma do potencial de ação foram medidos submetendo-se o neurônio modelado a correntes exatamente iguais ao limiar de disparo de potenciais de ação por um período de $0,2 \mathrm{seg}$. 42

Tab. 7. Célula em cesto. Os parâmetros quantitativos referentes à forma do potencial de ação foram medidos submetendo-se o neurônio modelado a correntes exatamente iguais ao limiar de disparo de potenciais de ação por um período de $0,2 \mathrm{seg}$. 44

Tab. 8. Parâmetros para os canais iônicos modelados como condutâncias ativas. Onde há dois valores, o primeiro se refere a partícula $\mathrm{m}$ (ativação) e o segundo se refere à partícula h (inativação). Os valores de $\tau$ foram mantidos constantes nestes canais. Estes parâmetro foram baseados em dados retirados da literatura (BERNANDER, et al., 1991). 67

Tab. 9. Parâmetros utilizados na modelação dos canais sinápticos. 69 


\section{ABSTRACT}

Since the discovery of the receptive field properties of cortical neurons in the primary visual cortex, their organization has been studied with many methods ranging from electrophysiology and optical imaging to computational neuroscience. Few models have been capable of showing ocularity and orientation selectivity simultaneously. A large-scale computational model of the mammalian primary visual pathway was constructed using GENESIS 2.2. The model consists of $\sim 10,000$ biologically plausible neurons organized in eight arrays to represent sectors of two retinas, two laminae of the dorsal lateral geniculate nucleus and two laminae of the visual cortex (each cortical lamina composed of a matrix of excitatory neurons and a matrix of inhibitory neurons). The physiological and architecture properties of the model were derived from experimental data for the mammalian primary visual pathway. Neurons have shown ocular and orientation selectivity dependent responses in good agreement with data. Though neurons in the cortex have shown markedly heterogeneity in the tuning responses, the latency of response was uniform and in good agreement with reported data. 


\section{SUMÁRIO}

Desde as descobertas das propriedades dos campos receptivos dos neurônios corticais no córtex visual primário, sua organização tem sido estudada com o auxílio de diversos métodos como eletrofisiologia, imageamento cortical e neurociência computacional. Poucos modelos mostram-se capazes de apresentar dominância ocular e seletividade à orientação simultaneamente. Um modelo em larga escala do sistema visual primário de mamíferos foi construído usando o GENESIS 2.2. O modelo contém aproximadamente 10.000 neurônios biologicamente plausíveis em oito matrizes representando setores das duas retinas, duas lâminas do núcleo geniculado lateral dorsal e duas lâminas representando o córtex visual (cada lâmina composta por uma matriz de células excitatórias e uma matriz de células inibitórias). As propriedades fisiológicas e estruturais do modelo foram determinadas com base em dados experimentais do sistema visual primário de mamíferos. Os neurônios apresentaram respostas binoculares e seletividade à orientação em boa concordância com os resultados experimentais. Apesar de neurônios corticais terem mostrado grande heterogeneidade em seus níveis de seletividade, a latência da resposta manteve-se constante e em boa concordância com resultados experimentais. 
Modelação do processamento visual primário em mamíferos - Capítulo I.

\section{Capítulo I}

\section{Introdução.}

No início do século XIX, James Breasted, diretor das Antiguidades Orientais na Universidade de Chicago decifrou um papiro datado do século XVII antes de nossa era. Este manuscrito médico é um compêndio de técnicas cirúrgicas onde, pela primeira vez na história, surge o hieróglifo para a palavra cérebro (KANDEL et al., 1991). Neste documento encontra-se uma relação de quarenta e oito casos clínicos envolvendo ferimentos na cabeça e no pescoço. Há, para cada caso, designação, exame, diagnóstico e tratamento. O caso oito merece algum destaque: o escriba nota que submetido a um "ferimento no crânio", o doente "caminha arrastando os pés”. J-P Changeux aponta que esta observação deve tê-lo surpreendido porque repete quatro vezes no espaço de poucas linhas, "este ferimento no crânio" como que para insistir na aparente incongruência de uma insuficiência motora manifestar-se em membros tão distantes do ferimento (CHANGEUX, 1991).

Registros sobre as relações entre o comportamento e suas bases biológicas têm-se acumulado desde a época dos antigos egípcios e aquilo que causou surpresa ao escriba não chama mais atenção hoje em dia. O sistema nervoso, em geral, e o cérebro em particular, estão comprovadamente envolvidos na organização e apresentação do comportamento. Mas se se conhece sua implicação na ocorrência do comportamento o mesmo não pode ser dito sobre o seu funcionamento. Como o cérebro funciona?

Para empreender este projeto capaz de investigar o funcionamento do cérebro foi necessário o surgimento de importantes tecnologias que permitiram o registro de uma enorme quantidade de dados sobre o cérebro, desde aspectos neuroanatômicos passando por registros eletrofisiológicos e técnicas de imageamento que permitem examinar a atividade do cérebro durante a ocorrência de um comportamento específico até a caracterização estrutural de moléculas e canais iônicos. Ao mesmo tempo, o desenvolvimento de computadores permitiu que esta enorme quantidade dados fosse submetida a métodos de analise que, sem o seu auxílio, seriam inexequíveis e além disso, que modelos descritivos sobre funcionamento do cérebro fossem implementados matemáticamente.

Durante o desenvolvimento das neurociências, o estudo dos sistemas sensoriais desempenhou papel de importância incontestável. À princípio, a idéia de que a organização de uma dada área do cérebro, de alguma forma, guardaria relação com o tipo de comportamento em que estaria implicada parecia óbvia devido a um dos princípios de operação dos sistemas sensoriais: a seletividade. Além 
Modelação do processamento visual primário em mamíferos - Capítulo I.

de cada sistema ser sensível a apenas uma modalidade sensorial, percebeu-se que alguns deles são sensíveis a localização espacial e diferenças de contraste (BARLOW, 1989).

Além disso, alguns neurônios menos periféricos que os receptores apresentam propriedades complexas que resultam de uma organização peculiar de suas conexões. Em 1938, Hartline descobriu uma certa área do campo visual que, quando submetida a apresentação de pontos luminosos, promove uma alteração na taxa de disparos das células ganglionares. A esta região foi dado o nome de campo receptivo (CR) (HARTLINE, 1938). Em 1953, Kuffler apresentou a forma do campo receptivo das células ganglionares da retina, cujos axônios formam o nervo óptico. A topografia destes campos receptivos é composta de um disco central e de uma região anular à sua margem (KUFFLER, 1953). Observou-se que estas regiões, em algumas classes de células, apresentam propriedades antagônicos. Quando a região central é estimulada ocorre um aumento da taxa de disparos ao passo que, a estimulação da região anular leva a uma diminuição da taxa de disparos. Desde então, o estudo do processamento visual evoluiu através do mapeamento das propriedades dos campos receptivos de neurônios por toda a extensão do sistema visual.

À medida que se avança ao longo do sistema visual, as propriedades dos campos receptivos mostram-se cada vez mais complexas. As células do córtex visual primário de mamíferos (V1), são seletivas a vários tipos de estimulação, incluindo localização na retina, ocularidade (dominância exercida por um olho sobre células corticais em detrimento do outro olho), orientação dos estímulos, entre outros (SWINDALE, 1998). Estas propriedades estão organizadas no córtex de uma maneira regular. E esta regularidade, peculiar a cada propriedade específica, é freqüentemente descrita em função de sua variação ao longo do deslocamento bidimensional paralelo à superfície cortical. A estes padrões regulares de variação dá-se o nome de mapas corticais. Os mapas corticais são estudados através do registro das propriedades eletrofisiológicas de neurônios ao longo da superfície cortical, ou através do uso de técnicas de imageamento cortical capazes de apresentar os níveis de atividade do córtex durante o período de estimulação (FITZPATRICK, 2000). Estes estudos mostram que células vizinhas têm propriedades semelhantes. Assim, células que recebem sinais de neurônios localizados em regiões próximas na retina estão próximas no cortex. Isto constitui o chamado mapa retinotópico (MR). Superposto a este mapa, há um outro organizado em função da dominância ocular. Há regiões cuja atividade é determinada essencialmente pela estimulação oriunda de um olho e regiões cuja atividade é determinada pela estimulação vinda do outro olho. Assim, apesar de haver uma pequena quantidade de neurônios monoculares isto é, que recebem entradas de apenas um olho, em algumas camadas (especialmente aquelas que recebem as entradas e as transmitem às demais células), os neurônios podem ser classificados de acordo com 
Modelação do processamento visual primário em mamíferos - Capítulo I.

sua ocularidade de forma contínua ao longo do córtex. Estas regiões em que neurônios respondem preferencialmente a estímulos de olhos diferentes constituem o mapa de dominância ocular (MDO). Há ainda regiões em que neurônios vizinhos respondem a estímulos em orientações específicas. Alterações de alguns graus na orientação do estímulo podem fazer com que a resposta destes neurônios seja diminuída pela metade ou menos. A organização destas regiões recebe o nome de mapa de seletividade à orientação (MSO).

Além desta organização topográfica bidimensional, o córtex também obedece a um padrão de organização que se estabelece ao longo de suas camadas, de forma vertical. Este tipo de organização é comumente referido como sistema colunar ou modular. As propriedades que determinam a aglutinação dos neurônios em regiões corticais permanecem razoavelmente constantes por sua extensão vertical. Este arranjo que permite aos neurônios em uma mesma coluna apresentar propriedades semelhantes se deve a um padrão de conexão em que diversos neurônios, especialmente das camadas 2 e 3 , estendem seus axônios para as demais camadas de forma perpendicular à superfície cortical determinando as propriedades funcionais de outros neurônios. Além disso, o padrão de inervação talâmica parece desempenhar um papel importante na determinação da organização espacial de neurônios corticais com propriedades semelhantes. Os sistemas colunares existentes no córtex visual primário (V1) são, naturalmente, análogos àqueles descritos utilizando-se mapas corticais. A ocularidade e a seletividade à orientação costumam ser referidas como colunas de dominância ocular (CDO) e colunas de seletividade à orientação (CSO), respectivamente (MOUNTCASTLE, 1997). Estes dois modos de organização cortical, dispõem de extensas evidências experimentais para apoiá-los e têm sido utilizados como inspiração na construção de modelos descritivos sobre a organização e funcionamento do cérebro.

Um modelo descritivo é uma hipótese formulada com base em aspectos experimentais em diversos níveis (biofísicos, morfológicos, neuroanatomicos etc.) para explicar as respostas de estruturas e neurônios individuais e relacioná-las ao comportamento de organismos. Modelos descritivos, entretanto, nem sempre podem ser facilmente testados, ou seja, muitas hipóteses não podem ser submetidas a uma avaliação experimental devido às dificuldades práticas envolvidas; presença de variáveis intervenientes cuja ação sobre os fenômenos estudados não pode ser eliminada de maneira confiável, por exemplo. Há ainda, ocasiões em que variáveis de difícil acesso como a condutância associada a um tipo de canal sináptico em uma classe de neurônios corticais deve ser registrada com o intuito de avaliar a contribuição de um conjunto de entradas específicas sobre as propriedades integrativas de uma população de neurônios. Situações como esta podem ser abordadas através de modelos computacionais. 
Modelação do processamento visual primário em mamíferos - Capítulo I.

O exemplo clássico de modelo computacional de propriedades neurofisiológicas de células é a geração de potencial de ação no axônio gigante da lula desenvolvido na década de 50 por A. L. Hodgkin e A. F. Huxley. A geração do potencial de ação é o resultado da interação de canais iônicos dependentes da voltagem e do tempo presentes na membrana. Os aspectos dinâmicos destes canais foram modelados por um conjunto de equações diferenciais resolvidas numericamente. Os parâmetros que permitiram a geração de dados semelhantes àqueles observados em experimentos foram encontrados através de um processo longo de tentativas para fitar o comportamento das correntes presentes na membrana (HODGKIN \& HUXLEY, 1952). Estas correntes, à época em que o modelo foi desenvolvido, eram conhecidas mas os canais foram um postulado teórico cuja existência só foi confirmada muitos anos depois graças ao desenvolvimento de técnicas de registro de canais individuais (NEHER \& SACKMANN, 1976).

Este exemplo ilustra o papel e a importância de modelos computacionais em neurociência. A investigação por meio de modelo computacional permitiu que a existência e funcionamento de canais iônicos fossem previstos muito tempo antes de sua comprovação tornar-se possível. Mais do que isto, permitiu formular hipóteses que não se restringiram às evidências experimentais disponíveis naquele momento e direcionaram experimentos que se seguiram. Esta é, sem dúvida, uma das grandes vantagens do uso de modelos computacionais: a troca de informações que se estabelece entre os ramos teórico e experimental em neurociência (BOWER \& BEEMAN, 1997).

À área que engloba a construção de modelos computacionais biologicamente plausíveis de neurônios ou estruturas do sistema nervoso dá-se o nome de neurociência computacional ${ }^{1}$ (KOCH \& SEGEV, 1989). Utilizando esta abordagem é possível modelar matematicamente o comportamento de um neurônio ou de uma rede de neurônios utilizando como parâmetros dados neurofisiológicos experimentalmente obtidos, investigar o comportamento destas estruturas ou neurônios, gerar dados que têm correspondência direta com aqueles gerados pelo sistema biológico real e, por fim, fazer predições sobre o seu funcionamento e organização.

O objetivo deste trabalho é a implementação de uma simulação biologicamente plausível do sistema visual de mamíferos que permita a investigação das propriedades dos campos receptivos de neurônios corticais. Foram propostos diversos modelos para a geração de propriedades como orientação (SOMERS et al. 1995) e ocularidade e para o desenvolvimento dos mapas e sistemas colunares que descrevem sua organização macroscópica (GOODHILL, 1998). Este trabalho objetivou a implementação de um modelo biologicamente plausível capaz de apresentar seletividade

\footnotetext{
Há ainda uma segunda razão para o nome neurociência computacional. O termo computacional implica a relação entre o cérebro e o computador como duas estruturas devotadas ao processamento de informação. Deste ponto de vista, se fosse implementado um modelo de estrutura cerebral com papel e lápis, ainda assim, seria parte da neurociência computacional.
} 
Modelação do processamento visual primário em mamíferos - Capítulo I.

à ocularidade e orientação do estímulo. Para tanto, o modelo foi composto por neurônios compartimentais com canais iônicos implementados seguindo o formalismo proposto por HODGKIN \& HUXLEY (1952). O modelo desenvolvido neste trabalho não visa apresentar mapas topográficos quantitativamente semelhantes àqueles apresentados em estudos de imageamento cerebral mas baseia-se fortemente neles para estabelecer a organização espacial dos padrões de conexão utilizados no córtex visual primário.

Os resultados gerados pelo modelo mostraram-se qualitativamente semelhantes àqueles apresentados em experimentos com animais. Diversos neurônios foram avaliados quanto à sua seletividade à ocularidade e à orientação. A seletividade à ocularidade dos neurônios apresenta-se em acordo com os principais resultados experimentais. Células da camada de entrada do córtex mostraram-se essencialmente monoculares e células das demais camadas mostraram-se responsivas a estímulos de ambos os olhos com clara dominância exercida por um deles.

A seletividade à orientação apresentou-se de forma bastante heterogênea. Neurônios apresentaram níveis de seletividade à orientação bastante diversos. Algumas células mostraram-se extremamente sintonizadas enquanto outras apresentaram níveis de seletividade regulares e outras ainda, apresentaram sensibilidade ao contraste. Estes resultados estão, aparentemente, relacionados a estratégias adotadas na implementação do modelo.

Nos próximos capítulos, revisaremos os principais aspectos celulares, citoarquitetônicos e neuroanatômicos envolvidos na organização do sistema visual de mamíferos, a construção e a implementação do modelo serão descritas e discutidas e os principais resultados gerados pelo modelo serão apresentados e discutidos. 
Modelação do processamento visual primário em mamíferos - Capítulo II.

\section{Capítulo II}

\section{Revisão.}

A abordagem conhecida como neurociência computacional é complementar a outras abordagens clássicas nas neurociências. A possibilidade de testar hipóteses por meio de modelos computacionais apresenta-se como um recurso de grande valia. Entretanto, a construção de modelos computacionais não é uma atividade abstrata. Os primeiros passos na construção de um modelo envolvem uma compilação de dados acerca dos fenômenos que se pretende investigar e das estruturas implicadas em sua organização. A não observância desta etapa, além de não garantir a identificação do modelo com as estruturas biológicas que o inspiraram, tornaria suspeita a avaliação das hipóteses geradas pelo modelo. Esta compilação de dados deve abarcar todos os aspectos relevantes ao nível de modelação que se pretende implementar.

Neste capítulo é apresentada uma revisão sobre os dados relativos aos neurônios, os elementos essenciais na construção deste modelo, às estruturas que compõem o sistema visual e aos fenômenos de seletividade a padrões encontrados no córtex visual. Todos os dados listados aqui foram obtidos por meio de levantamento bibliográfico.

A maior parte dos dados sobre neurônios contidos nesta revisão foi colhida em gatos ou ratos. Entretanto, os padrões de conexão, citoarquitetura, densidade celular etc. relativos às estruturas descritas foram, em sua maioria, colhidos em primatas. Ao longo do texto, as semelhanças e dessemelhanças serão comentadas quando necessário.

\section{Neurônios.}

Os neurônios do córtex visual são inervados pelos axônios das células de relê talâmicas e estas, por sua vez, pelas fibras que compõem o nervo óptico formado pelos axônios das células ganglionares da retina. Os corpos das células ganglionares compõem a camada mais externa da retina. Seus dendritos penetram nas camadas mais internas e recebem contatos sinápticos excitatórios das células bipolares e contatos sinápticos excitatórios e inibitórios das células amácrinas. Estas duas classes de células se conectam umas às outras por meio de células horizontais e recebem os sinais dos cones e bastonetes, os dois tipos de fotoreceptores da retina de mamíferos.

Como foi dito no capítulo anterior, os campos receptivos de células ganglionares da retina estão organizados em função de seu padrão de conexão e apresentam duas sub-regiões circulares e 
Modelação do processamento visual primário em mamíferos - Capítulo II.

concêntricas com propriedades antagônicas. Com base nisto, propôs-se uma classificação. Neurônios que, quando submetidos a iluminação no centro do campo receptivo apresentam aumento de sua excitação (em decorrência disto, da frequência de descargas de potenciais de ação) e quando submetidos a iluminação na periferia apresentam inibição (diminuição da frequência de descargas de potenciais de ação), recebem o nome de neurônios de ativação central (ON-Center). Ao passo que, aqueles que apresentam propriedades opostas (com inibição central e excitação periférica) são definidos como neurônios de inibição central (OFF-Center). Em geral predomina a propriedade do centro quando os neurônios são submetidos a iluminação homogênea em todo o campo receptivo (KUFFLER, 1953).

Observou-se que células ganglionares da retina de gatos e primatas podem ser ainda classificadas de acordo com critérios funcionais que se superpõem àqueles acima citados. Em gatos, há células que são extremamente sensíveis a diferenças de contraste e apresentam um padrão de resposta que se mantém pela duração do estímulo ainda que ocorra flagrante diminuição da frequência de disparos ao longo do período. Estas células recebem o nome de células X. Uma outra classe apresenta um padrão de resposta transiente e sensível a alterações bruscas de iluminação, recebem o nome de células Y. Uma terceira classe ainda apresenta seletividade à direção e é conhecida como classe W. As células X têm campos receptivos menores e velocidade média de condução que é aproximadamente metade daquela apresentada pelas células Y. Ambas projetam-se para o Núcleo Geniculado Lateral do tálamo (NGL). Em primatas, por outro lado, foi estabelecida uma classificação anatômica de acordo com as zonas de projeção. As células que se projetam para as camadas parvocelulares recebem o nome de células $\mathrm{P}$ e aquelas que se projetam para as camadas magnocelulares são definidas como M (STERLING, 1998). Observou-se, entretanto, que esta distinção anatômica pode indicar uma distinção funcional similar àquela presente em gatos. As propriedades funcionais das células do canal $\mathrm{M}$ são essencialmente semelhantes às do canal $\mathrm{X}$ no que diz respeito à sensibilidade a diferenças de contraste (SHAPLEY \& PERRY, 1986). As propriedades do canal $\mathrm{P}$ seriam uma adaptação característica de primatas para garantir sensibilidade às cores.

Os neurônios de relê talâmicos representam a grande maioria das células em qualquer núcleo talâmico. Estes neurônios projetam-se para o cortex com uma inervação colateral para o núcleo reticular talâmico (SHERMAN \& KOCH, 1998). Os neurônios do núcleo geniculado lateral recebem sinapses excitatórias das células ganglionares da retina, de outras aferências subcorticais, de aferências corticais oriundas da camada 6 dos córtices visuais primário e secundário e sinapses inibitórias de neurônios GABAérgicos do próprio NGL. Podem ser divididos em diversas classes de 
Modelação do processamento visual primário em mamíferos - Capítulo II.

acordo com a sua localização, morfologia e com as classes de neurônios que os inervam. Em vista da coleção de canais iônicos que possuem e da miríade de contatos sinápticos que recebem, apresentam comportamentos bastante dinâmicos.

Em diversas espécies de mamíferos, neurônios talâmicos mostram-se capazes de apresentar dois modos de operação. O primeiro modo corresponde a disparos individuais ou em conjuntos de potenciais de ação. Este modo é conhecido como modo de disparo tônico e nele, um potencial de ação é gerado a cada vez. O segundo modo é conhecido como modo de disparo em rajada. Neste modo, o neurônio gera um conjunto de potenciais de ação (2-10 potenciais de ação convencionais) em alta frequência com intervalos entre potenciais de ação (IPA) $\leq 0,004$ seg e em seguida permanece silencioso por períodos de até $0,1 \mathrm{seg}$, alternando períodos de alta frequência e períodos de silêncio. O modo de disparo em rajada pode ser gerado por injeção de corrente hiperpolarizadora, por ação de potenciais sinápticos inibitórios, ou por alteração do potencial de repouso da célula. A alteração do potencial de repouso parece ser responsável pela atividade espontânea de alguns núcleos talâmicos e pela geração de oscilações entre os circuitos tálamo-corticais (DESCHÊNES et al., 1984). Estas oscilações serviriam como um filtro das informações sensoriais durante o sono e outras circunstâncias em que o estado de alerta está diminuído (McCORMICK \& FEESER, 1990).

As células estreladas da camada 4 dos córtices sensoriais primários de diversas espécies têm sido consideradas como o principal alvo dos axônios talâmicos. A síntese da informação que é realizada por estes neurônios é uma etapa crucial no processamento cortical da atividade aferente (LUND, 1984).

Estes neurônios relembram os neurônios corticais piramidais no que diz respeito a sua morfologia, fisiologia e densidade relativa. Nas camadas corticais em que estão presentes, normalmente são os neurônios mais numerosos. Além disso, as células estreladas assemelham-se aos neurônios piramidais quanto a sua sinaptologia. A quase totalidade dos contatos sinápticos recebidos por estes neurônios no soma e nos dendritos proximais é de natureza inibitória. Contatos sinápticos inibitórios são também encontrados em seus dendritos distais. Entretanto, em quantidade muito menor à medida que se afasta-se do soma. $\mathrm{O}$ número absoluto de contatos sinápticos recebidos no soma é pequeno (DOUGLAS \& MARTIN, 1998). Os axônios das células estreladas fazem contatos sinápticos excitatórios usando o NMDA como neurotransmissor. As principais distinções são: ao contrário dos neurônios piramidais, as células estreladas não possuem dendrito apical; sua árvore dendrítica permanece na mesma camada em que está o seu soma na maior parte dos casos; muito raramente seus axônios projetam-se para os córtices secundário (V2), terciário 
Modelação do processamento visual primário em mamíferos - Capítulo II.

(V3) ou para estruturas sub-corticais; a maior parte dos casos os alvos dos contatos sinápticos estão na mesma camada ou em camadas próximas (LUND, 1984).

Apesar de comporem a grande maioria das células em qualquer camada em que estejam presentes, as células estreladas e piramidais dividem espaço com outros neurônios corticais. Os interneurônios correspondem a uma população morfologicamente heterogênea de células corticais que realizam conexões com os neurônios piramidais e células estreladas próximas. Apesar de comporem uma classe morfologicamente heterogênea, estes neurônios têm em comum o fato de utilizar o GABA como neurotransmissor. Sem dúvida, as mais comuns são as células em cesto. Estas células costumam apresentar frequências mínimas de geração de potenciais de ação próximas a $70 \mathrm{~Hz}$, ou mais altas. É muito provável que estes interneurônios exerçam algum papel de natureza importante na modulação e desenvolvimento dos campos receptivos (DOUGLAS \& MARTIN, 1998). Os neurônios GABAérgicos correspondem a um faixa entre 15 e $20 \%$ das populações de todas camadas corticais. Na camada 4C, os neurônios GABAérgicos corresponde a $20 \%$ da população total de neurônios. O GABA é considerado o principal neurotransmissor inibitório do córtex cerebral (JONES \& HENDRY, 1984).

\section{Estruturas.}

Diversos estudos em neurofisiologia têm descrito as vias de condução relacionadas ao processamento de informação visual primária. O sistema visual está organizado em séries de estações interconectadas (HUBEL, 1987). No sistema visual de mamíferos, a retina de cada olho é composta por neurônios que podem ser organizados em três camadas. Os receptores, no sistema visual de primatas por exemplo, correspondem à primeira camada e podem ser agrupados em duas categorias: cones e bastonetes. Em seguida o sinal é passado para a segunda camada que é composta por células bipolares, amácrinas e horizontais. A terceira camada corresponde às células ganglionares cujos axônios reunidos formam o nervo óptico. Cada uma das classes de neurônios descritos acima é composta por diversos tipos de células. Estas células podem ser distinguidas umas das outras através de sua morfologia, fisiologia e sinaptologia (STERLING, 1998).

O nervo óptico de gatos contém aproximadamente, 160.000 axônios. Em primatas, este número aumenta para 1.800.000. Diferentes tipos de células ganglionares enviam diferentes tipos de informação para áreas diferentes do cérebro. Assim, o núcleo do nervo óptico é composto por axônios de células ganglionares seletivas à direção do movimento que se projetam para o colículo superior. Outras ainda, projetam-se para o núcleo supraquiasmático que utiliza esta informação para gerenciar ritmos circadianos. Estas células, em geral têm corpos celulares e diâmetros pequenos (10 
Modelação do processamento visual primário em mamíferos - Capítulo II.

x $10^{-6} \mathrm{~m}$ e $0,3 \times 10^{-6} \mathrm{~m}$ ) e, em decorrência disto, ocupam menos do que $5 \%$ da secção transversal do nervo óptico. No gato, estes grupos de células que se projetam para núcleos subcorticais envolvidos com o gerenciamento de funções básicas correspondem a 40\% do total (STERLING, 1998). Em primatas esta proporção é de apenas 10\% (RODIECK, 1988).

Os nervos ópticos dos dois olhos unem-se na base do crânio para formar o quiasma óptico. No quiasma óptico cerca de metade das fibras do nervo óptico cruza para o lado oposto; a outra metade permanece do mesmo lado, formando o trato óptico, junto com o axônios cruzados do nervo óptico do lado oposto. Portanto, pelo trato óptico de cada hemisfério seguem cerca de um milhão de axônios provenientes das células ganglionares das duas retinas que dirigem-se à primeira estação sub-cortical do sistema visual: o núcleo geniculado lateral. O cruzamento das fibras ao longo do quiasma obedece à seguinte regra: as fibras oriundas da retina temporal do olho esquerdo e da retina nasal do olho direito seguem pelo trato óptico esquerdo, ao passo que o trato óptico direito é formado por fibras provenientes da retina nasal do olho esquerdo e da retina temporal do olho direito.

O tálamo é a principal fonte de entradas para o córtex (SHERMAN \& GUILLERY, 1996). Diversos estudos o caracterizam apenas como uma estação intermediária no envio de sinais nervosos. Boa parte das evidências em favor desta avaliação do tálamo são oriundas de estudos do sistema visual. Observou-se que as propriedades dos campos receptivos das células talâmicas mostram-se essencialmente inalteradas em relação àquelas células da retina que as inervam ${ }^{2}$ (SCHILLER \& MALPELI, 1978). Em primatas, o NGL recebe as entradas dos axônios das células ganglionares da retina em lâminas separadas (1-6) em um padrão monosináptico. Estas lâminas são agrupadas em dois conjuntos principais: magnocelular e parvocelular. As lâminas pertencentes ao conjunto magnocelular são as mais ventrais (1-2) e as lâminas pertencentes ao parvocelular, as mais dorsais (3-6). Os neurônios do canal magnocelular têm respostas transientes e fazem parte de um sistema de transmissão rápida. Os neurônios do canal parvocelular, por sua vez, respondem a estímulos estacionários e formam uma entrada de baixa velocidade para o córtex (PETERS et al., 1994). Os axônios da maioria dos neurônios do núcleo geniculado lateral seguem pela radiação óptica até o córtex visual primário que se localiza no lobo occipital do cérebro. No NGL de gatos a separação física entre os canais X e Y não é tão marcante quanto a separação entre o canais M e P em primatas. Neurônios do canal X e do canal Y inervam de maneira indiscriminada as lâminas A e

\footnotetext{
Há evidências mais recentes (SHERMAN \& GUILLERY, 1996) sobre propriedades importantes das células talâmicas (HUGENARD \&McCORMICK, 1992) que, aliadas ao fato de que o tálamo além de receber entradas dos sistemas sensoriais, é modulado pelas mesmas áreas corticais que inerva (SHERMAN \& KOCH, 1998), depõem em favor de um papel mais ativo desta estrutura na transmissão dos sinais nervosos para o córtex (JONES, 1998). Entretanto que papel seria este é uma questão que permanece obscura.
} 
Modelação do processamento visual primário em mamíferos - Capítulo II.

indiscriminada as lâminas A e A1 do NGL de gatos. Entretanto, os neurônios talâmicos recebem entradas quase exclusivamente de células ganglionares funcionalmente semelhantes a eles em qualquer lâmina (SHERMAN \& KOCH, 1986). Apesar da diferença entre a segregação no NGL dos canais $\mathrm{X}$ e $\mathrm{Y}$, em gatos e $\mathrm{M}$ e $\mathrm{P}$, em primatas, no córtex a segregação esta preservada (SHERMAN \& KOCH, 1986). A inervação dos canais X e Y se faz em porções separadas da camada 4 de gatos de maneira análoga à inervação dos canais $\mathrm{M}$ e $\mathrm{P}$, em primatas na camada $4 \mathrm{C}$.

Em todos os mamíferos, o córtex consiste em uma série de camadas de células superpostas com uma espessura total de aproximadamente $2 \mathrm{~mm}$. Estas camadas ou lâminas são em número de 6 ainda que em algumas áreas este número possa variar. O estudo deste padrão laminar teve início no século XIX e recebeu o nome de citoarquitetura. O estudo da citoarquitetura do córtex é a base para a sua divisão em áreas distintas. Comparações entre diversas áreas corticais (áreas motoras e sensoriais de diversas modalidades) em diversas espécies (ratos, gatos, primatas e humanos), demonstram que apesar de a área cortical total variar entre as espécies, o número absoluto de neurônios em uma unidade de volume constante, uma coluna com $30 \times 10^{-6} \mathrm{~m}^{2}$. de área de base que se estende por toda a extensão vertical do córtex, não varia. O número de neurônios de diferentes áreas corticais também permanece constante se avaliado desta forma. A exceção é o córtex visual primário que possui, 2,5 vezes mais neurônios do que as demais áreas (ROCKEL et al., 1980). O córtex visual primário recebe o nome de V1 mas é também conhecido como córtex estriado. No córtex visual, as terminações do NGL são encontradas especialmente na camada 4 e na camada 6, com maior concentração na camada 4 (PETERS et al., 1994). Em gatos as conexões seguem da camada 4 para as camadas 2 e 3 que, por sua vez, projetam-se para a camada 5 que envia projeções para a camada 6 que, por fim, envia conexões para a camada 4. Isto sem falar nas conexões que são enviadas para estruturas subcorticais e para outras áreas visuais (BOLZ et al., 1989). Em primatas, ao contrário de gatos, existem mais do que 6 camadas. As camadas $2 / 3$ e 4 são subdivididas. A camada $4 \mathrm{C}$ no córtex visual de primatas corresponde à camada 4 em gatos e as camadas 2-4B correspondem às camadas 2 e 3 em outras áreas corticais. As camadas 2-4B subdividem-se em 2, 3A, 3B, 4A e 4B enquanto a camada 4C é dividida em 4C $\alpha$ (parte superior da camada 4C) e 4C $\beta$ (parte inferior da camada 4C) (CALLAWAY, 1998). Em primatas, a camada 4C é o principal alvo das projeções talâmicas. Os neurônios estrelados desta camada enviam projecções para a camada 24B. As camadas que compõem o conjunto 2-4B enviam projeções para a camada 5 e esta envia projeções (menos densas que em gatos) para a camada 6. As projeções mais densas da camada 5 seguem para a camada 2-4B formando o laço entre estas duas camadas (2-4B e 5). Os neurônios da 
Modelação do processamento visual primário em mamíferos - Capítulo II.

camada 6 podem ser divididos em duas populações distintas de acordo com os alvos de suas projeções. A primeira população projeta-se densamente para a camada 2-4B enquanto a segunda projeta-se, também densamente, para a camada 4C (CALLAWAY, 1998). Todos os padrões de conexão apresentados acima são de natureza excitatória tanto em gatos quanto em primatas. Os alvos dos neurônios inibitórios permanecem confinados às suas camadas de origem em sua grande maioria.

O sistema visual de mamíferos, além de ser organizado como uma série de estações interconectadas, pode também ser caracterizado como extremamente paralelo. Existem diversos canais de informação que se formam desde a retina e em estruturas intermediárias; permanecendo segregados até o córtex visual primário (BLASDEL \& LUND, 1983; SHERMAN \& GUILLERY, 1996; YABUTA \& CALLAWAY, 1998). Alguns autores sugerem que as interações entre estes canais servem como base para o surgimento de processamentos de informação mais complexos em áreas extra-estriadas (YABUTA \& CALLAWAY, 1998). Esta característica do sistema visual o torna extremamente atrativo enquanto alvo de estudos de modelação pois permite que determinados canais sejam modelados de forma independente de outros sem que haja prejuízo para implementação do modelo e posterior interpretação dos resultados. Esta abordagem foi adotada no desenvolvimento deste trabalho e apenas o canal $\mathrm{M}$ do sistema visual foi modelado. Em vista disto, daqui para frente, os dados relativos aos demais canais só serão abordados se necessário.

Além dos dados relativos à citoarquitetura e a descrição qualitativa dos padrões de conexão entre as estruturas, há uma enorme quantidade de informações que interessa ao modelador. Parâmetros como a densidade de neurônios, e os fatores de magnificação que determinam o padrão de conexão entre uma estrutura, aquelas que a inervam e aquelas que são por ela inervadas, são de suma importância para o dimensionamento do modelo. Além disso, é preciso investigar o padrão de conexão entre neurônios de uma mesma estrutura e determinar a 'força' das sinapses entre estas células.

$\mathrm{Na}$ retina, por exemplo, a densidade de células ganglionares varia de acordo com a excentricidade, ou seja, a densidade das células ganglionares diminui de acordo com a distância da fóvea. Um fator complicador é o fato de estas densidades não decaírem igualmente na retina nasal e temporal. Na região marginal à fóvea e até $1 \mathrm{~mm}$ de excentricidade, a densidade mantém-se bastante alta com valores superiores a 50.000 células por $\mathrm{mm}^{2}$. À medida que a excentricidade vai aumentando, estes valores decaem rapidamente. Entre $3 \mathrm{~mm}$ e $4 \mathrm{~mm}$ estes valores variam de pouco mais de 20.000 até 10.000 células por $\mathrm{mm}^{2}$ para a retina nasal. A densidade não decai para menos de 800 células por $\mathrm{mm}^{2}$ para a retina nasal. Por outro lado, os valores relativos à retina temporal são 
Modelação do processamento visual primário em mamíferos - Capítulo II.

bem mais baixos e o decaimento da densidade das células ganglionares é ainda mais rápido variando de pouco menos de 20.000 até pouco mais de 5.000 células por $\mathrm{mm}^{2}$ para a mesma faixa de valores de excentricidade apresentada para a retina nasal. Em $12 \mathrm{~mm}$ de excentricidade a densidade alcança seu mínimo em torno de 100 células por mm² (WÄSSLE, et al., 1989).
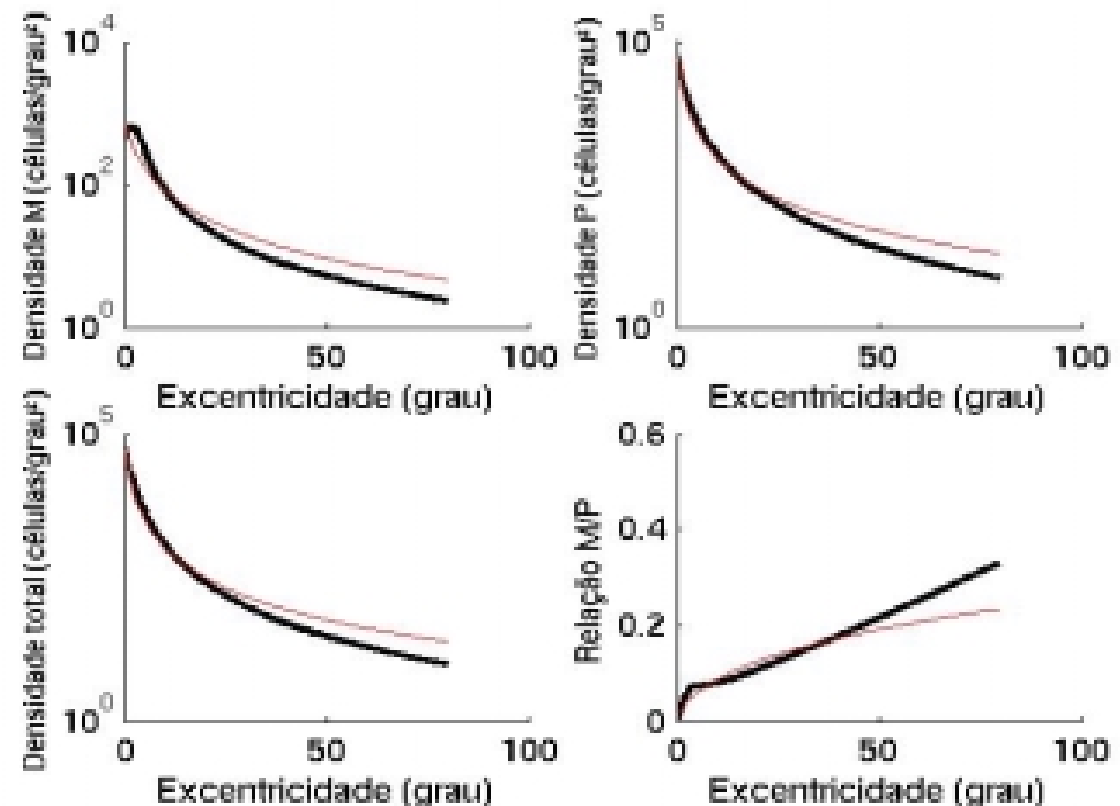

Figura 1. Os dois primeiros gráficos apresentam (da esquerda para a direita) as melhores aproximações para as funções de magnificação (células/grau²) para os canais $M$ e $P$ do NGL de primatas, respectivamente, em escala semi-logarítmica. $O$ primeiro gráfico da segunda linha corresponde a soma das funções dos dois primeiros gráficos da primeira linha acrescidos de $10 \%$, em escala semi-logarítmica. A superposição da densidade de células ganglionares da retina (WÄSSLE et al., 1990) sobre a função de magnificação mostrou boa concordância. O último gráfico descreve a relação entre a densidade de células no canal $M$ e a densidade de células no canal $P$ do NGL em função da excentricidade. Todos os dados apresentados em traço espesso foram obtidos utilizando as equações apresentadas em MALPELI et al. (1996) e as curvas apresentadas em traço vermelho foram retiradas de SCHEIN \& MONASTERIO (1987).

Schein e Monasterio revisaram os dados da literatura sobre o padrão de projeção da retina para o NGL e deste núcleo talâmico para o córtex em primatas. Segundo estes autores $90 \%$ das células ganglionares na camada mais externa da retina projetam-se para NGL do tálamo. Reavaliando os estudos mais expressivos, esta investigação estabelece uma taxa unitária de conexão entre a retina e o NGL para valores de excentricidade inferiores a $40^{\circ}$. Estes autores propõem que, no sistema visual de primatas, cada célula ganglionar inerva um neurônio de relê talâmico, aproximadamente. Este dado permite estabelecer a densidade de neurônios das camadas do NGL por extensão do padrão de inervação das células ganglionares da retina (SCHEIN \& MONASTERIO, 1987). Entretanto, esta avaliação foi feita tomando por base a quantidade de fibras do nervo óptico e a quantidade de 
Modelação do processamento visual primário em mamíferos - Capítulo II.

neurônios do NGL. Não há estimativas sobre o número de células ganglionares das classes M e P na retina de primatas.

Em vista disto, o número de células das classes $\mathrm{M}$ e $\mathrm{P}$ foi calculado no próprio NGL de primatas. As densidades destas duas classes de células variam de acordo com a excentricidade (Fig. 1) e somadas respondem pela grande maioria das células do NGL (MALPELI et al., 1996). Acrescentando às densidades de células M e P calculadas no NGL, o valor de $10 \%$, correspondente à porcentagem de células que não se projetam da retina para NGL, e superpondo a esta curva, as densidades da população total de células ganglionares da retina (WÄSSLE et al., 1990), obteve-se uma ótima aproximação (MALPELI et al., 1996). Esta nova evidência depõe a favor da teoria de que existe uma relação bastante estreita entre a retina e o NGL o que permite que a densidade de células em uma das estruturas sirva como um bom preditor da densidade de células na outra. Além disso, as propriedades dos campos receptivos das células nestas estruturas são semelhantes, o que confere mais credibilidade à idéia de que o padrão de conexão entre estas estruturas não envolve altos índices de convergência ou divergência. A figura 1 apresenta estas aproximações e superpõe os traços gerados pelos dados apresentados por SCHEIN \& MONASTERIO (1987) e por MALPELI et al. (1996). Estas curvas foram traçadas utilizando as equações fornecidas pelos autores nos artigos citados acima.

Há evidências de que a relação entre a inervação das células ganglionares da retina ipsilateral e da retina contralateral é de um para um, ou seja, metade das células do NGL recebem contatos sinápticos da retina ipsilateral e a outra metade da contralateral (SCHEIN \& MONASTERIO, 1987). Segundo a classificação estabelecida por SHILLER \& MALPELI (1978), os contatos referentes ao olho contralateral são realizados nas lâminas mais dorsais dos conjuntos funcionais (M e P) enquanto os contatos referentes ao olho ipsilateral são feitos nas lâminas mais ventrais dodos conjuntos funcionais (M e P) do NGL de primatas. Para o canal M, respectivamente, lâminas 1 e 2. Esta projeção é essencialmente topográfica mantendo-se um padrão em que células vizinhas na retina inervam células vizinhas do NGL. A maior parte destas sinapses são realizadas nos dendritos próximos ao soma e raramente no próprio soma (SHERMAN \& KOCH, 1998).

$\mathrm{O}$ córtex visual de primatas mede $1,5 \mathrm{~mm}$ de espessura e pode ser dividido em diversas camadas. Existem dois esquemas principais para divisão do córtex em camadas. O mais utilizado e mais antigo é o modelo proposto por Brodmann no início do século. Bonin propôs um esquema alternativo na década de 40 (PETERS, 1997). Nesta revisão, o esquema proposto por Brodmann é utilizado. 
Modelação do processamento visual primário em mamíferos - Capítulo II.

Os axônios dos neurônios de relê talâmicos penetram nas camadas corticais através da substância branca gerando alguns ramos colaterais na camada 6 e seguindo para a camada 4 onde geram seus terminais axonais finais. A camada 4B não recebe qualquer entrada do NGL enquanto o canal P, composto pelas lâminas parvocelulares talâmicas inerva as camadas $4 \mathrm{~A}, 4 \mathrm{C} \beta$ e 6 e o canal M, composto pelas lâminas magnocelulares talâmicas, inerva as camadas 4C $\alpha$ e 6 (PETERS et al., 1994). A camada $4 C \alpha$, por sua vez, envia sinais para a camada 4B. A camada $4 C \beta$ envia axônios para as camadas 2 e 3 . Este padrão de conexão mantém segregados os canais que se originam na retina (YABUTA \& CALLAWAY, 1998). Neste modelo estaremos simulando apenas as camadas $4 \mathrm{C} \alpha$ e $4 \mathrm{~B}$.

É comumente aceito que a densidade de neurônios corticais não varia de acordo com a excentricidade. Entretanto, devido a variação na densidade de neurônios do NGL, a quantidade de área cortical devotada ao processamento de uma área constante do campo visual varia de acordo com a excentricidade. Diversos pesquisadores desenvolveram medidas para avaliar esta variação que tem sido commumente chamada de fator de magnificação cortical (FMC). O FMC é uma magnitude que descreve em uma dada excentricidade, a distância que se deve deslocar no cortex para que se possa mover $1^{\circ}$ na representação retinotópica do campo visual. Em contraposição a esta medida linear, tem-se utilizado o fator de magnificação cortical areal (FMCA) que corresponde a variação da quantidade de área cortical devotada ao processamento de uma área do campo visual de acordo com a excentricidade $\left(\mathrm{mm}^{2} / \mathrm{grau}^{2}\right)$ (SCHEIN \& MONASTERIO, 1987). O FMCA em primatas está descrito na figura 2. utilizando-se as melhores aproximações para os dados de TOOTELL et al, (1988) que utilizaram deoxiglicose para estudar o mapeamento retinotópico entre $0^{\circ}$ e $10^{\circ}$, VAN ESSEN et al., (1984) que utilizaram o mapeamento eletrofisiológico para determinação do FMCA entre 2,5 e $80^{\circ}$ e HUBEL \& FREEMAN (1977) que também estimaram o FMCA utilizando registros eletrofisiológicos entre $1^{\circ}$ e $22^{\circ}$. Há uma semelhança grande para valores de excentricidade inferiores a $4^{\circ}$ entre os dados do primeiro e último estudos. Estas estimativas foram utilizadas no desenvolvimento de uma descrição que corresponde a uma média delas (Fig 2) (MALPELI et al., 1996). Se o número de células corticais é realmente constante independente da excentricidade, então o FMCA deve ser proporcional à densidade de células ganglionares (células/grau ${ }^{2}$ ) apresentadas para as duas classes de células talâmicas M e P na figura 1. Esta hipótese, conhecida como dimensionamento periférico, vem acumulando evidências (WÄSSLE et al., 1989; WÄSSLE et al., 1990; MALPELI et al., 1996). Esta teoria permite que seja estimado o número de células talâmicas por unidade de área cortical, a densidade aferente (células $/ \mathrm{mm}^{2}$ ), para 
Modelação do processamento visual primário em mamíferos - Capítulo II.

as classes de células do NGL (Fig. 2). Estas curvas foram traçadas utilizando as equações fornecidas pelos autores nos artigos citados acima e na legenda da figura.
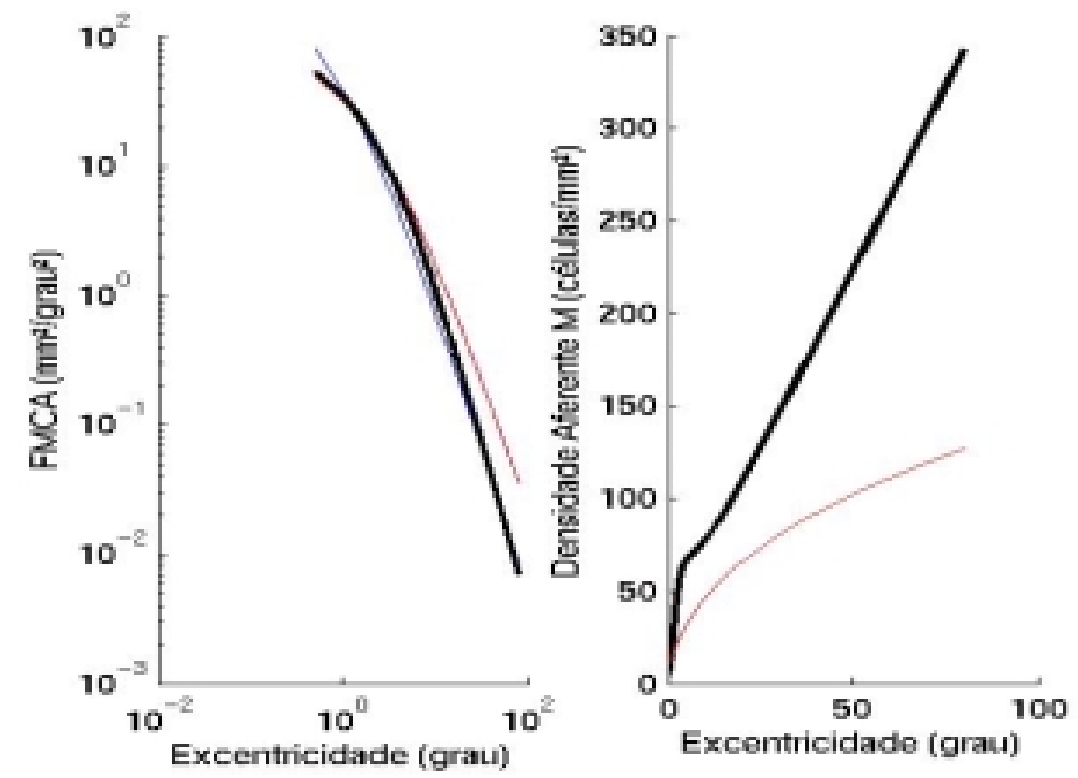

Figura 2. As curvas apresentadas no primeiro gráfico são as melhores aproximações para as funções de magnificação cortical areal apresentadas na literatura em escala logarítmica. Em vermelho (TOOTELL et al., 1988), em azul (VAN ESSEN et al., 1984), e em laranja, (HUBEL \& FREEMAN, 1977). Em preto, o traço mais espesso corresponde à média dos demais estudos calculada por MALPELI et al. (1996). No segundo gráfico estão apresentadas as curvas que descrevem a densidade aferente para o canal M. Em vermelho (SCHEIN \& MONASTERIO, 1987), em preto, o traço mais espesso, (MALPELI et al., 1996).

Existe um padrão paralelo de convergência e divergência na passagem de informação do NGL para o córtex. A divergência é determinada pelo fato de que tanto a área como a densidade de neurônios do córtex são maiores do que a área e a densidade de neurônios do NGL. A convergência, por outro lado, deve-se à forma dos terminais axonais dos neurônios talâmicos. Estes terminais são amplos e inervam diversos neurônios corticais e não só aqueles que guardam uma estreita relação topográfica com as células talâmicas (BLASDEL \& LUND, 1983). Em vista disto, neurônios corticais podem receber inervação de células talâmicas com as quais não estão em perfeito alinhamento topográfico.

Foram realizadas análises morfológicas e eletrofisiológicas de terminais axonais que apresentam arborização nas camadas associadas com as entradas talâmicas (4A, 4C, 4C e 6). Entre os 38 terminais avaliados, 11 apresentaram arborização na camada 4C e sua origem talâmica foi comprovada por meio de registro eletrofisiológico. A investigação da forma de um destes terminais axonais demonstrou que ele se estende por uma região ampla de $1 \mathrm{~mm}$ por 0,8 $\mathrm{mm}$ (compondo uma área curva de $0,4 \mathrm{~mm}^{2}$ ). Um outro terminal que, além de arborizações na camada 4C também 
Modelação do processamento visual primário em mamíferos - Capítulo II.

apresenta colaterais que inervam a camada 6, possui uma morfologia peculiar. Observado da superfície da pia, o terminal deste axônio estende-se por duas bandas paralelas, com larguras próximas de $300 \times 10^{-6} \mathrm{~m}$ separadas por uma região de também 300 × 10-6 $\mathrm{m}$ de largura (BLASDEL \& LUND, 1983). Estes autores propõem que o arranjo presente na camada 4C está correlacionado à organização das CDO. O terminais axonais talâmicos presentes na camada 4C, por sua vez, apresentam uma forma bastante regular e inervam neurônios em uma região aproximadamente circular com raio igual a $180 \times 10^{-6} \mathrm{~m}$.

Resultados semelhantes àqueles encontrados por BLASDEL \& LUND (1983), foram encontrados por WU et al. (1998). Utilizando uma amostra maior, estes autores encontraram um padrão de arborização semelhante àquele previamente descrito; terminais axonais alongados com o eixo maior paralelo às bandas de dominância ocular, área média de cobertura dos terminais igual $0,13 \mathrm{~mm}^{2}\left( \pm 0,02 \mathrm{~mm}^{2}\right)$ com valor mínimo igual a $0,05 \mathrm{~mm}^{2}$ e máximo igual $0,24 \mathrm{~mm}^{2}$ (WU et al., 1998).

A organização das entradas talâmicas com terminais axonais alongados, assimétricos e amplos (especialemnte na camada 4C ) (BLASDEL \& LUND, 1983) e o arranjo bastante preciso do mapa retinotópico (HUBEL \& FREEMAN, 1977; V. ESSEN et al., 1984; TOOTELL et al., 1988), ainda esperam por uma conciliação. É provável que os mapas retinotópicos devam sua excelente precisão essencialmente à organização das entradas talâmicas do canal parvocelular na camada 4C que possui terminais essencialmente regulares e densidade aferente maior do que a encontrada na camada 4C .

Tab. 1. Dados básicos referentes ao padrão de entrada do canal M em VI; densidades totais de neurônios nas camadas 4C e $(4 B 1+4 B 2)$; percentagens médias de neurônios GABAérgicos em V1. A última coluna da tabela contém as referências de onde foram coletados os valores.

\begin{tabular}{l|l|l}
\hline Grandeza. & Valor. & Referencia. \\
\hline Densidade de neurônios (4C ). & $17,3 \times 10^{3} \mathrm{c}$. por $\mathrm{mm}^{2}$. & (O'KUSKY \& COLONIER, 1982) \\
\hline Densidade de neurônios (4B1+4B2). & $21,2 \times 10^{3} \mathrm{c}$. por $\mathrm{mm}^{2}$. & (O'KUSKY \& COLONIER, 1982) \\
\hline Densidade de neurônios GABAérgicos. & $25 \% \mathrm{em}$ todas as camadas. & (PETERS et al., 1994) \\
\hline Densidade de neurônios GABAérgicos. & $15 \% \mathrm{em}$ todas as camadas. & (ROSIER et al., 1993) \\
\hline Área ocupada por terminais axonais M do NGL. & $>0,3 \mathrm{~mm}^{2} \mathrm{e}<0,4 \mathrm{~mm}^{2}$. & (BLASDEL \& LUND, 1983) \\
\hline Área ocupada por terminais axonais M do NGL. & $0,13( \pm 0,02) \mathrm{mm}^{2}$. & (WU et al., 1998) \\
\hline
\end{tabular}

Revisando dados quantitativos sobre o padrão de entrada do NGL no córtex visual de primatas, PETERS et al. (1994) descrevem o padrão de arborização axonal de neurônios de relê talâmicos na 
Modelação do processamento visual primário em mamíferos - Capítulo II.

camada $4 \mathrm{C} \alpha$. A superfície média de cobertura de uma árvore axonal de um neurônio talâmico estaria entre $0,4 \mathrm{~mm}^{2}$ e $0,3 \mathrm{~mm}^{2}$.

Os principais alvos dos axônios das células de relê talâmicos das lâminas magnocelulares do NGL são as células estreladas da camada $4 \mathrm{C} \alpha$. Estas células têm árvores dendríticas restritas a esta camada na maioria dos casos. Estas árvores estendem-se por áreas circulares com raios que variam de $180 \times 10^{-6} \mathrm{~m}$ a $200 \times 10^{-6} \mathrm{~m}$ (BLASDEL \& FITZPATRICK, 1984). As projeções axonais destes neurônios são recorrentes com diversos ramos colaterais terminando nas camadas $4 \mathrm{C} \alpha$ e $4 \mathrm{~B}$ e raramente na camada 4A (LUND \& BOOTHE, 1975). Alguns ramos podem ainda gerar colaterais que inervam neurônios presentes nas camadas 5 e 6 (LUND, 1984).

Existem 17,3 x $10^{3}$ neurônios e $37 \times 10^{6}$ sinapses em $1 \mathrm{~mm}^{2}$ de superfície cortical na lâmina 4C $\alpha$ (O'KUSKY \& COLONIER, 1982). A camada 4B recebe conexões da camada 4C $\alpha$ e da camada 6 (LUND \& BOOTHE, 1975; LUND, 1984). Segundo O'KUSKY e COLONIER (1982), pode-se perceber diferenças quantitativas entre as densidades de neurônios nas partes superior e inferior da camada 4B. Por conta disso, em suas medidas, esta camada foi dividida em duas: 4B1 e 4B2. A densidade de neurônios nas partes superior e inferior corresponde a 12,2 x $10^{3}$ e 9,0 x $10^{3}$. Somando-se as densidades das partes superior e inferior desta camada, obtém-se a densidade total de $21,2 \times 10^{3}$ neurônios e $52,2 \times 10^{6}$ sinapses em $1 \mathrm{~mm}^{2}$ de superfície cortical na lâmina 4B. Há variadas estimativas para o número de neurônios que utilizam o GABA como neurotransmissor em V1. A maior parte delas oscila entre $15 \%$ e $25 \%$ do número total de neurônios (PETERS et al., 1994; ROSIER et al., 1987) em todas as camadas. A concentração de receptores do tipo NMDA é maior nas camadas 2, 4C e 5, mas independente de retinotopia ou do padrão de inervação talâmica, em primatas (FITZPATRICK et al., 1987).

Não se sabe qual a organização espacial do padrão de inervação da camada $4 \mathrm{C} \alpha$ sobre a camada 4B. O que se sabe, por meio de estudos funcionais de eletrofisiologia, é que as células da camada 4C $\alpha$ possuem campos receptivos que relembram em muito os campos das células do NGL. São, em sua maioria, monoculares e pouco seletivas à orientação (HUBEL \& WIESEL, 1968; HUBEL \& WIESEL, 1977; CALLAWAY, 1998). Por outro lado, as células da camada 4B são binoculares e apresentam seletividade à orientação. A binocularidade é, provavelmente, fruto da convergência de entradas dos dois olhos segregadas na camada $4 \mathrm{C} \alpha$. Já a seletividade a orientação, ainda não teve sua origem explicada no cortex de primatas (CALLAWAY, 1998). 
Modelação do processamento visual primário em mamíferos - Capítulo II.

\section{Mapas Corticais e Sistemas Colunares.}

O padrão de conexão entre estruturas do sistema visual pode ser descrito através dos parâmetros apresentados acima. Entretanto, ainda é necessário, averiguar o padrão de conexão entre neurônios de diferentes camadas do córtex. Para tanto, os estudos sobre mapas corticais e sistemas colunares são de grande utilidade. Estes estudos fornecem as poucas indicações de que se dispõe para montagem dos padrões de conexão em V1. Desde os trabalhos clássicos em eletrofisiologia do córtex visual de mamíferos sabe-se que neurônios do córtex visual estão organizados em grupos (HUBEL \& WIESEL, 1962). O primeiro princípio de agrupamento é a similaridade da localização dos campos receptivos. Outro princípio de agrupamento importante é a preferência a classes de estímulos (HUBEL \& WIESEL, 1968). Desta forma, neurônios são agrupados em padrões macroscópicos nas laminas. As propriedades de resposta de neurônios variam ao longo do deslocamento horizontal do córtex formando mapas corticais e permanecem essencialmente constantes ao longo da dimensão vertical do córtex formando colunas corticais (CALLAWAY, 1998).

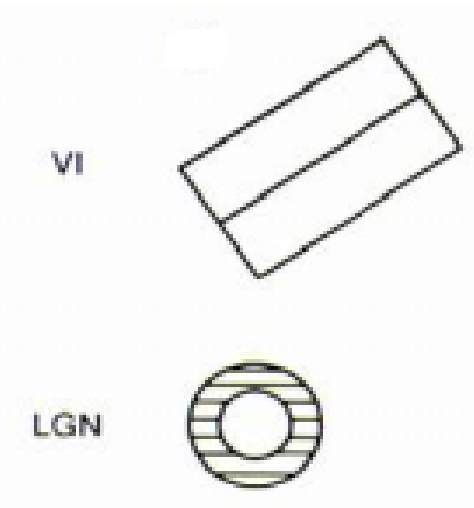

O córtex contém um pequeno mapa de como o mundo é visto através dos olhos. Ainda que a projeção topográfica da retina sobre o córtex visual seja bastante precisa, em uma escala celular este mapa não é contínuo. Estudos eletrofisiológicos desenvolvidos demonstraram que diversas células no córtex visual apresentam campos receptivos binoculares que têm a mesma posição no campo visual em qualquer um dos olhos (HUBEL \& WIESEL, 1977).

Figura 3. Os campos receptivos Contudo estas células variam sua responsividade a depender da origem concêntricos das células do sinal. Algumas delas respondem com maior intensidade a estímulos ganglionares contrastam com os campos receptivos seletivos à apresentados ao olho ipsilateral; outras ao olho contralateral e, por fim, orientação das células simples do córtex visual. Adaptado de outras respondendo com intensidade igual a estímulos de ambos os (WEHMEIER, et al., 1989) olhos. Em humanos, macacos, gatos e em muitas outras espécies, os sinais originados nas duas retinas são segregados em áreas alternadas servindo ao olho direito e ao olho esquerdo (HUBEL \& WIESEL, 1972). Este fenômeno pode ser observado com surpreendente regularidade. Estas variações de dominância ocular obedecem a um arranjo colunar. Assim, células em uma mesma coluna tendem a responder preferencialmente a estímulos apresentados ao mesmo olho. O papel da experiência visual na segregação destas entradas é ainda extremamente polêmico. Uma variedade de manipulações experimentais mostrou-se capaz de alterar o desenvolvimento das 
Modelação do processamento visual primário em mamíferos - Capítulo II.

colunas de dominância ocular durante o período crítico que se aglutina ao redor das primeiras semanas de vida. Aparentemente, a experiência visual desempenha algum papel mas, além dela, padrões de atividade neural espontâneos presentes na retina também afetam a organização deste sistema colunar (WU et al., 1998).

Além das Colunas de Dominância Ocular existem outros sistemas colunares no córtex. Grupos de neurônios do córtex visual primário de vários mamíferos (especialmente camada 4) respondem de maneira seletiva a estímulos em forma de barra em orientações específicas (HUBEL \& WIESEL, 1968; HUBEL \& WIESEL, 1977; HUBEL, 1987). Quando a imagem de uma barra ou linha é rodada em $20^{\circ}-30^{\circ}$ da orientação em que mais eficientemente ativa uma determinada célula cortical, as células no NGL, que inervam as células corticais, quase não alteram a magnitude de sua resposta. Entretanto, o neurônio cortical cessa sua resposta (FERSTER \& MILER, 2000). A forma e o comportamento dos campos receptivos dos neurônios talâmicos são semelhantes aos das células ganglionares da retina. Há um centro e um anel periférico. Já as células corticais possuem um campo receptivo alongado com uma região excitatória e uma região inibitória (Fig. 3).

O mecanismo exato que o cérebro utiliza para apresentar esta sensibilidade a barras em orientações diferentes não é, entretanto, completamente compreendido havendo interpretações divergentes especialmente no que diz respeito ao papel da circuitaria intracortical no córtex visual (FERSTER \& KOCH, 1987).

Através de medidas eletrofisiológicas, HUBEL \& WIESEL (1977) postularam um módulo de circuitaria cortical que seria responsável pelo processamento visual. Este módulo seria repetido com mínimas variações ao longo de V1 e ocuparia uma área aproximadamente igual $1 \mathrm{~mm}^{2}$. De acordo com esta proposta, a seletividade à orientação varia de forma aproximadamente contínua por distâncias que variam entre $500 \times 10^{-6}$ e $750 \times 10^{-6} \mathrm{~m}$. Estas distâncias são semelhantes às larguras das bandas que correspondem às CDOs. Segundo este modelo, uma região contendo duas colunas de dominância ocular conteria também um número suficiente de CSOs para processar informação visual com mínima superposição dos campos receptivos.

Desde então, sistemas colunares passaram a ser estudados intensivamente com imageamento cerebral (BLASDEL \& SALAMA, 1986). Graças a esta tecnologia, a organização destes dois mapas corticais pode ser investigada em uma mesma região do córtex visual de primatas. Estes estudos demonstraram que o padrão de organização geral dos mapas corticais de seletividade à orientação assume a forma de conjuntos de cata-ventos. Há certas regiões em que a variação da seletividade à orientação se dá de maneira contínua e outras em que isto não ocorre. Estas regiões lineares 
Modelação do processamento visual primário em mamíferos - Capítulo II.

parecem ocupar $50 \%$ do córtex e frequentemente estão localizadas nas bordas das CDOs e as intersectam com orientações ortogonais (MOUNTCASTLE, 1997).

As variações não lineares podem ser classificadas em diversos grupos. Singularidades são áreas pontuais ao redor das quais, a seletividade varia de forma contínua de $0^{\circ}$ ate $180^{\circ}$. Fraturas são descontinuidades abruptas onde a seletividade altera-se bastante em variações pequenas de deslocamento cortical horizontal. Por fim, há as selas que são regiões nas quais a seletividade à orientação permanece constante em uma área mais extensa do que o normal para uma CSO. As selas, em geral encontram-se em áreas delimitadas por quatro singularidades. Qual a função destas não linearidades é um ponto que ainda espera por elucidação (BLASDEL, 1992).

Mas o ponto principal é como conciliar estes estudos com o padrão de conexão cortical. É possível medir a atividade de neurônios excitatórios e inibitórios mas a localização e o padrão de conexão destes neurônios permanece controverso. As investigações eletrofisiológicas permitem apenas avaliar o papel da excitação e da inibição na determinação das propriedades dos campos receptivos mas a origem destes potenciais sinápticos permanece polêmica.

Utilizando imageamento cortical em paralelo com estudos morfológicos de neurônios individuais, MALACH et al. (1993), observaram que o padrão de arborização axonal e dendrítica de neurônios do córtex visual primário não guarda qualquer tipo de relação com a organização dos sistemas colunares. Pelo menos, no que diz respeito às conexões de curto alcance. Estas conexões estendem-se por uma região com forma circular e diâmetro de $400 \times 10^{-3} \mathrm{~m}$ e inervam células de diversas orientações (inclusive orientações ortogonais às da célula pré-sináptica). Já as conexões de longo alcance, tendem a unir colunas compostas por células que possuem propriedades fisiológicas semelhantes. Estas conexões estendem-se por alguns milímetros e conectam regiões de mesma dominância ocular e de seletividade à orientação relativamente semelhantes (MALACH et al., 1993). As evidências encontradas em primatas foram também encontradas em ferrets (WELIKY et al., 1995) e em gatos (KISVÁRDAY et al., 1997). 
Modelação do processamento visual primário em mamíferos - Capítulo III.

\section{Capítulo III}

\section{O Modelo.}

O processo de construção de um modelo pode ser dividido, para efeito didático, em algumas etapas. A primeira delas corresponde ao levantamento de dados utilizados na construção do modelo. Incluídas aí, estão as propriedades passivas e ativas de membrana de cada neurônio bem como os dados relativos ao dimensionamento das estruturas modeladas e o padrão de conexão entre elas. As propriedades passivas correspondem a forma do neurônio (ex. a forma da árvore dendrítica, o diâmetro do soma etc.) e ao modo como a corrente flui na célula (ex. a resistência específica de membrana, a capacitância específica de membrana e a resistência axial.). As propriedades ativas, por sua vez, correspondem à ação efetivada pela interação de um conjunto variado de canais iônicos sobre o comportamento do neurônio. Depois de definidos estes dados, eles devem ser convertidos em elementos computacionais e em seguida, reunidos em neurônios que devem se comportar de forma semelhante aos neurônios descritos na literatura. Para construir estruturas de forma biologicamente plausível, é necessário que se disponha de dados sobre a densidade de neurônios e de sinapses, descrições quantitativas, se possível, do padrão de conexão entre estas estruturas etc. Frequentemente, estes dados envolvem valores altos e, em decorrência disto, é preciso estabelecer fatores de escala. As estruturas são então modeladas como matrizes de células ou conjuntos de matrizes.

O levantamento dos dados utilizados na construção do modelo está sumariado no capítulo anterior. Neste capítulo serão apresentados os neurônios modelados, a organização das estruturas construídas e o padrão de conexões estabelecido entre elas.

\section{Neurônios.}

As células ganglionares são o canal de saída da retina; seus axônios reunidos formam o nervo óptico. As terminações destes nervos fazem contatos sinápticos com os neurônios de relê do NGL. Contudo, as respostas da células ganglionares são determinadas pelo conjunto de canais iônicos e pelos contatos sinápticos a que estão submetidas. Há, pelo menos, uma dezena de canais iônicos envolvidos e um padrão de citoarquitetura dinâmico que muda de acordo com a excentricidade. A inclusão das células ganglionares da retina no modelo foi implementada por meio de uma estratégia computacional diferente da utilizada para a implementação dos neurônios do NGL e do córtex. 
Modelação do processamento visual primário em mamíferos - Capítulo III.

Foi implementado um modelo de célula ganglionar que não é composto por compartimentos ou canais iônicos como as demais células. Trata-se de um 'objeto' amorfo capaz de produzir disparos de forma aleatória de acordo com uma probabilidade determinada. É possível determinar a amplitude e o período refratário absoluto destes disparos. Esta estratégia fornece uma grande vantagem; tornar a simulação mais leve e portanto permitir que a capacidade de processamento seja reservada para as demais estruturas que utilizam modelos de neurônios mais complexos e maior número de conexões (NGL e V1). A determinação da probabilidade de disparo está descrita no apêndice II e corresponde a uma aproximação funcional do campo receptivo destas células.

Os demais neurônios foram implementados de acordo com o formalismo descrito no apêndice I. Os parâmetros relevantes para a construção destes neurônios estão listados a seguir para cada modelo de neurônio individual.

Para as células de relê talâmicas:

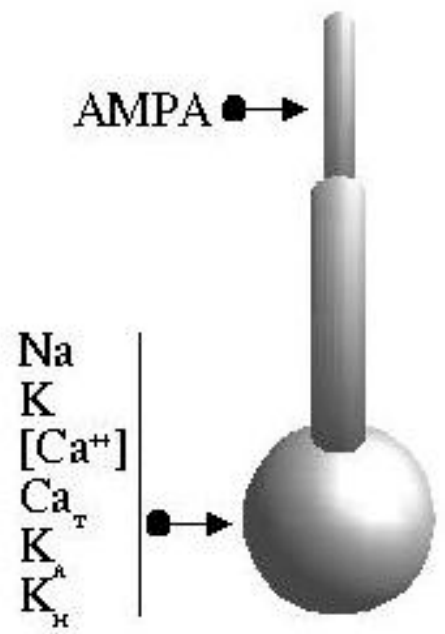

Figura 4. Representação esquemática do neurônio de relê talâmico do NGL desenvolvido neste trabalho. A distribuição dos canais iônicos e sinápticos está ilustrada na figura.

Tab. 1. Parâmetros utilizados na construção dos neurônios de relê talâmicos do NGL. A última coluna da tabela contém as referências de onde foram coletados os valores.

\begin{tabular}{l|r|l}
\hline Grandeza. & Valor. & Referência. \\
\hline Resistência específica da membrana $\left(R_{M}\right)$. & $0,55 \mathrm{~m}^{2}$. & (BLOOMFIELD et al., 1987) \\
\hline Capacitância especifica de membrana $\left(C_{M}\right)$. & $0,011 \mathrm{~F} / \mathrm{m}^{2}$. & (CONNORS et al., 1982) \\
\hline Resistência axial específica de membrana $\left(R_{A}\right)$. & $0,7 \mathrm{~m}$. & (SEGEV, 1995) \\
\hline Potencial de repouso $(m V)$. & $-0,060 \pm 0,0055 \mathrm{~V}$. & (BLOOMFIELD et al., 1987) \\
\hline Potencial de repouso. & $-0,062 \pm 0,0020 \mathrm{~V}$. & (DESCHÊNES et al., 1984) \\
\hline
\end{tabular}


Modelação do processamento visual primário em mamíferos - Capítulo III.

\begin{tabular}{l|r|l}
\hline Grandeza. & Valor. & Referência. \\
\hline Potencial de repouso. & $-0,063 \mathrm{~V}$. & (McCORMICK \& HUGENARD, 1992) \\
\hline Constante de tempo $(\tau)$ & $0,0224 \mathrm{seg}$. & (DESCHÊNES et al., 1984) \\
\hline Constante de tempo. & $0,014 \mathrm{seg}$. & (McCORMICK \& HUGENARD, 1992) \\
\hline Diâmetro e comprimento do soma. & $25 \times 25 \times 10^{-3} \mathrm{~m}$. & --- \\
\hline Diâmetro e comprimento do dendrito $(1)$ & 6 e $80 \times 10^{-3} \mathrm{~m}$. & -- \\
\hline Diâmetro e comprimento do dendrito $(2)$ & 4 e $50 \times 10^{-3} \mathrm{~m}$. & -- \\
\hline
\end{tabular}

O neurônio de relê talâmico simulado contém canais iônicos de sódio transiente ( $\mathrm{Na}$ ), potássio retificador $(K)$, cálcio de baixo limiar $\left(C a_{t}\right)$, potássio transiente $\left(K_{A}\right)$, potássio ativado por hiperpolarização $\left(K_{H}\right)$, e uma variação temporal na concentração de cálcio ([C $\left.\mathrm{Ca}^{++}\right]$). Como foi dito na sessão anterior, os neurônios de relê talâmicos são capazes de atuar em dois modos; modo de disparo tônico e modo de disparo em rajada. O modo de disparo em rajada parece estar intimamente relacionado com o nível de alerta do animal. Os animais utilizados em experimentos de estudos de campos receptivos, mensuração da atividade mediante a apresentação da estimulação específica e investigação de sistemas colunares estão, na maioria dos casos, alertas e o potencial de repouso das células permanece próximo a $-0,06 \mathrm{~V}$. como na tabela 2 . Em decorrência disto, é incomum a ocorrência de disparos em rajadas durante estes experimentos. Entretanto, o neurônio modelado mostrou-se capaz de operar nos dois modos de acordo com os dados descritos na literatura (SHERMAN \& KOCH, 1998). Os dados referentes aos parâmetros dos canais estão também descritos na literatura (BERNANDER, et al., 1991). Os parâmetros relativos ao canal de cálcio de baixo limiar e ao canal de potássio ativado por hiperpolarização estão descritos em outra fonte (McCORMICK \& HUGENARD, 1992). Os dados referentes aos parâmetros passivos estão sumariados na tabela 2. Os dados relativos às dimensões dos dendritos foram ajustados com base nas observações de BLOOMFIELD et al. (1987).

Para as células estreladas da camada 4:

Tab. 3. Parâmetros utilizados na construção das células estreladas da camada 4 do córtex visual. A última coluna da tabela contém as referências de onde foram coletados os valores.

\begin{tabular}{l|r|l}
\hline Grandeza. & Valor. & Referência. \\
\hline Resistência específica da membrana $\left(R_{M}\right)$. & $0,678 \Omega \mathrm{m}^{2}$. & (BUSH \& SEJNOWSKI, 1993) \\
\hline Capacitância especifica de membrana $\left(C_{M}\right)$. & $0,0295 \mathrm{~F} / \mathrm{m}^{2}$. & (BUSH \& SEJNOWSKI, 1993) \\
\hline Resistência axial específica de membrana $\left(R_{A}\right)$. & $2,0 \Omega \mathrm{m}$. & (BUSH \& SEJNOWSKI, 1993) \\
\hline Potencial de repouso $(m V)$. & $-0,0736 \pm 0,0051 \mathrm{~V}$. & (McCORMICK et al., 1985) \\
\hline Constante de tempo $(\tau)$. & $0,02 \mathrm{seg}$. & (BUSH \& SEJNOWSKI, 1993) \\
\hline Constante de tempo. & $0,0202 \pm-0,0146 \mathrm{seg}$. & (McCORMICK et al., 1985) \\
\hline
\end{tabular}


Modelação do processamento visual primário em mamíferos - Capítulo III.

\begin{tabular}{l|r|l}
\hline Grandeza. & Valor. & Referência. \\
\hline Diâmetro e comprimento do soma (hrz). & $24,6 \pm 7,3 \times 10^{-3} \mathrm{~m}$. & (CONNORS et al., 1982) \\
\hline Diâmetro e comprimento do soma (vrt). & $18,5 \pm 4,3 \times 10^{-3} \mathrm{~m}$. & (CONNORS et al., 1982) \\
\hline Diâmetro e comprimento dos Dendritos. & 4 e $80 \times 10^{-3} \mathrm{~m}$. & - \\
\hline Diâmetro e comprimento dos Dendritos. & 3 e $40 \times 10^{-3} \mathrm{~m}$. & -- \\
\hline
\end{tabular}

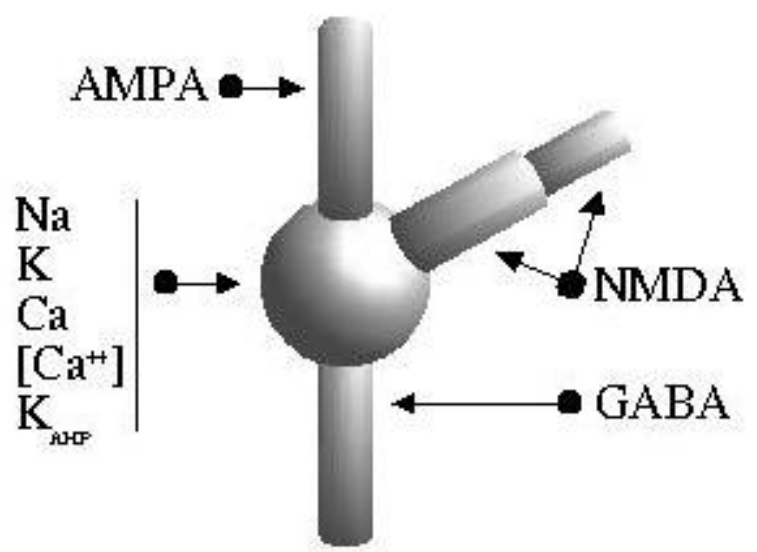

Figura 5. Representação esquemática da célula estrelada da camada 4 do cortex de mamíferos desenvolvida neste trabalho. A distribuição dos canais iônicos e sinápticos está ilustrada na figura.

Para gerar o comportamento biologicamente plausível, foram inseridos na célula estrelada simulada, canais iônicos de sódio transiente ( $\mathrm{Na}$ ), potássio retificador $(\mathrm{K})$, cálcio de alto limiar $(C a)$, potássio ativado por cálcio $\left(K_{A H P}\right)$ e uma variação temporal na concentração de cálcio

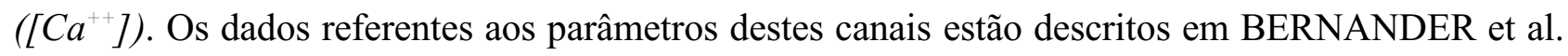
(1991) e no apêndice I. Os dados referentes aos parâmetros passivos estão sumariados na tabela 3. Vários dados apresentados nesta tabela foram registrados em células piramidais. A semelhança entre estas e as células estreladas permite que dados de uma classe sejam extrapolados para outra.

Para os interneurônios GABAérgicos (células em cesto):

Tab. 4. Parâmetros utilizados na construção dos interneurônios GABAérgicos do córtex visual. A última coluna da tabela contém as referências de onde foram coletados os valores.

\begin{tabular}{l|r|l}
\hline Grandeza. & Valor. & Referência. \\
\hline Resistência específica da membrana $\left(R_{M}\right)$. & $1,0 \Omega \mathrm{m}^{2}$. & (CONNORS et al., 1982) \\
\hline Capacitância especifica de membrana $\left(C_{M}\right)$. & $0,021 \mathrm{~F} / \mathrm{m}^{2}$. & (CONNORS et al., 1982) \\
\hline Resistência axial específica de membrana $\left(R_{A}\right)$. & $2,0 \Omega \mathrm{m}$. & (BUSH \& SEJNOWSKI, 1993) \\
\hline Potencial de repouso $(m V)$. & $-0,0716 \pm 0,0078 \mathrm{~V}$. & (McCORMICK et al., 1985) \\
\hline
\end{tabular}


Modelação do processamento visual primário em mamíferos - Capítulo III.

\begin{tabular}{l|r|l}
\hline Grandeza. & Valor. & Referência. \\
\hline Constante de tempo $(\tau)$. & $0,0119 \pm 0,0065 \mathrm{seg}$. & (McCORMICK et al., 1985) \\
\hline Diâmetro e comprimento do soma & $\sim 14 \times 19 \times 10^{-3} \mathrm{~m}$. & (AZOUZ, et al., 1997) \\
\hline Diâmetro e comprimento dos dendritos $(2)$ & $1 \mathrm{e} 270 \times 10^{-3} \mathrm{~m}$. & (AZOUZ, et al., 1997) \\
\hline
\end{tabular}

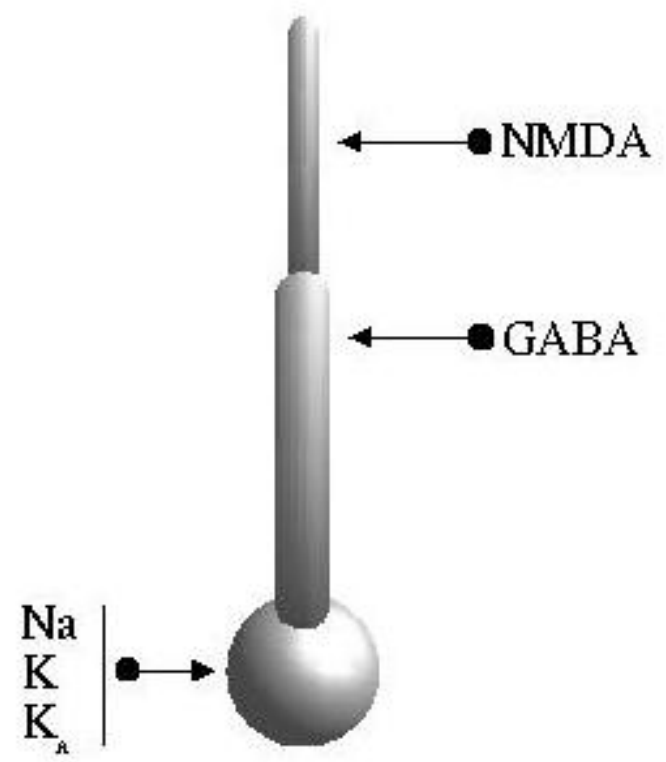

Figura 6. Representação esquemática do interneurônio GABAérgico (célula em cesto) da camada 4 do cortex de mamíferos desenvolvida neste trabalho. A distribuição dos canais iônicos $e$ sinápticos está ilustrada na figura.

No interneurônio GABAérgico (célula em cesto), foram inseridos canais iônicos de sódio transiente $(\mathrm{Na})$, potássio retificador $(\mathrm{K})$, potássio transiente $\left(K_{A}\right)$. Os dados referentes aos parâmetros destes canais estão descritos em BERNANDER et al. (1991) e no apêndice I. Os dados referentes aos parâmetros passivos estão sumariados na tabela 4.

Os valores das constantes de espaço e de tempo, os comprimentos eletrotônicos e as resistências de entrada relativos às células foram calculados e estão dentro de uma faixa aceitável segundo a revisão bibliográfica resumida nas tabelas.

Além disso, foram incluídos os canais sinápticos presentes nos neurônios utilizados. Foram utilizadas implementações de receptores de NMDA (N-metil-D-aspartato), AMPA (Ácido a-amino3-hidroxi-5-metilisoxazole-propriônico) e GABA (Ácido gama-amino-butírico). A estratégia empregada e os parâmetros utilizados na simulação destes canais estão apresentados no apêndice I.

Este é o elenco básico de neurônios constituintes do modelo. Uma célula de relê talâmica do NGL, uma célula estrelada da camada 4 do córtex visual primário, um interneurônio GABAérgico 
Modelação do processamento visual primário em mamíferos - Capítulo III.

do córtex visual primário (célula em cesto). O primeiro neurônio possui 3 compartimentos (o soma e 1 dendrito formado por dois compartimentos), o segundo, possui 5 compartimentos (o soma e três dendritos, um deles, formado por dois compartimentos) e o terceiro, 3 compartimentos (o soma e 1 dendrito formado por dois compartimentos). Os somas tiveram seus valores de diâmetro aproximados para formas esféricas e os dendritos para compartimentos cilíndricos.

O número de compartimentos foi escolhido de forma que os neurônios pudessem dispor de sítios proximais e distais onde fossem implementados os canais sinápticos, quando necessário. Naturalmente, foi escolhido um pequeno número de compartimentos para cada neurônio para que as simulações fossem exequíveis. Os valores de comprimento, diâmetro e resistência axial dos compartimentos foram ajustados para promover um fluxo de corrente que permitisse aos neurônios modelados apresentar um comportamento semelhante àquele descrito na literatura para cada classe de célula. No entanto, estes valores permaneceram dentro das faixas ou próximos àqueles descritos em investigações experimentais resumidas nas tabelas 2, 3 e 4. Os canais iônicos citados foram incluídos apenas nos somas. Os dendritos foram modelados como estruturas passivas. Os axônios não foram explicitamente incluídos no modelo. O potencial de ação gerado no soma é enviado ao neurônio pós-sináptico. Apenas um atraso, na maioria dos casos, mantido dentro da faixa descrita na literatura e calculado em função da distância entre os neurônios pré- e pós-sinápticos, foi estabelecido.

É importante frisar ainda que existem diversos outros tipos de neurônios presentes nas estruturas modeladas. Por exemplo, no NGL existem células inibitórias em todas as lâminas magnocelulares e parvocelulares. No córtex visual primário, além das células estreladas existe uma pequena população de neurônios piramidais na camada $4 \mathrm{~B}$ e, além das células em cesto, os interneurônios GABAérgicos modelados neste estudo, há uma grande variedade de células que também utilizam o GABA como neurotransmissor. Entretanto, optou-se por ignorar a população de células inibitórias do NGL, neste momento e considerar a população de células excitatórias do córtex como sendo exclusivamente formada por células estreladas nas duas camadas corticais (4C $\alpha$ e $4 \mathrm{~B})$ e a população de células inibitórias representada apenas por células em cesto.

Neurônios do sistema nervoso de mamíferos têm sido tradicionalmente classificados de acordo com suas características morfológicas ou de acordo com sua localização. Contudo, o neurônio não opera em um vácuo. Ele é, na verdade, um elemento de uma circuitaria complexa que tem papel importante na determinação de seu comportamento. Para entender o papel de um neurônio em uma circuitaria, é necessário, não só os dados de sua morfologia e sinaptologia, mas também dados que 
Modelação do processamento visual primário em mamíferos - Capítulo III.

descrevam de que maneira ele integra as entradas que recebe. Diferenças na densidade de canais iônicos e sinápticos, nas propriedades passivas de membrana, fazem com que neurônios de uma mesma região, apresentem comportamentos bastante diferentes. Estes comportamentos diferentes podem se mostrar na forma dos potenciais de ação individuais, ou na padrão temporal dos potenciais de ação que pode ser examinado submetendo-se a célula a injeções contantes de corrente.

Foi proposta uma classificação funcional dos neurônios de acordo com características fisiológicas tais como as propriedades biofísicas das membranas e a variação na distribuição e no tipo de canais iônicos nos somas e dendritos e em consequência disto, na forma de seus potenciais de ação e nos padrões distintos de disparos repetidos quando submetidos a injeções constantes de corrente (McCORMICK et al., 1985). Três classes principais de neurônios foram observadas no córtex de vários mamíferos. Os Neurônios de Disparo Regular (NDRes) são caracterizados por possuírem disparos longos devido a uma taxa lenta de repolarização. Cada disparo é seguido por complexos de pós-hiperpolarização e pós-despolarização. Quando estimulados exatamente no valor de seu limiar, geram apenas um único potencial de ação. Quando submetidos a estimulação prolongada e constante estes neurônios geram séries de potenciais de ação e exibem pronunciada adaptação (McCORMICK et al., 1985; CONNORS \& GUTNICK, 1990). Os Neurônios de Disparos Rápidos (NDRas) têm potenciais de ação que duram muito menos que os os potenciais dos NDRes. A duração média dos disparos em metade da amplitude do potencial de ação é, em média 0,32 ms (AZOUZ, et al., 1997). O que caracteriza mais fortemente os NDRas é o fato de que há pouca ou nenhuma adaptação em sua frequência de disparo quando submetidos a estimulação intracelular constante. Sua frequência de disparo é sensivelmente superior a NDRes.

Os Neurônios de Disparos em Rajadas (NDRajs) se distinguem por sua capacidade de gerar spikes em um conjunto ou rajada de dois a dez disparos. Estas rajadas são, em geral, a resposta mínima a um estímulo intracelular próximo ao limiar de disparo. Quando recebem estimulação intracelular prolongada e constante, estes neurônios geram padrões complexos com rajadas seguidas ocasionalmente por disparos individuais (CONNORS \& GUTNICK, 1990). Nos neurônios do tálamo, por outro lado, estes dois modos de operação encontram-se relativamente segregados ocorrendo de forma independente (ZHAN et al., 1999).

Através do estudos morfológicos e fisiológicos tornou-se possível estudar a correlação entre a forma e localização de células corticais e suas propriedades de membrana. Desta forma, torna-se possível sobrepor a classificação tradicional a esta nova classificação. Boa parte das células estreladas e piramidais se comportam como NDRes. Aparentemente, existe uma correlação positiva 
Modelação do processamento visual primário em mamíferos - Capítulo III.

entre os NDRas e as células inibitórias do córtex que usam GABA como neurotransmissor (CONNORS \& GUTNICK, 1990).

Os três neurônios construídos podem ser classificados cada um, em uma destas classes. A célula de relê talâmica pode ser caracterizada como um NDRaj, a célula estrelada, como um NDRe e a célula em cesto como NDRa.

\section{Estruturas.}

Os parâmetros apresentados no capítulo anterior foram escalonados e as estruturas envolvidas no processamento visual primário em mamíferos foram construídas como camadas de neurônios.

Tomando como base os trabalhos de modelação bem como os estudos sobre as características citoarquitetônicas das áreas envolvidas, dimensionou-se o modelo em três áreas: retina, NGL e V1. A retina é formada por duas matrizes correspondendo à população de células ganglionares do tipo M da classe "ON-center" de cada olho. Isto significa que há duas matrizes de células para modelar a retina. Estes modelos de neurônios ganglionares correspondem, na verdade, a uma aproximação fornecida por uma diferença de gaussianas. Este procedimento tem sido amplamente utilizado em modelagem de sistemas visuais gerando um padrão de resposta bastante semelhante ao das células ganglionares da retina (WÖRGÖTER \& KOCH, 1989; WEHMEIER et al., 1989; SOMERS, 1995). A estimação da projeção das células ganglionares sobre as células do NGL não envolve índices altos de convergência ou divergência e foi estabelecida com uma relação 1:1 (SCHEIN \& MONASTERIO, 1987). O NGL foi modelado como duas camadas de células talâmicas com as mesmas dimensões das camadas retinianas correspondendo aos canais das lâminas magnocelulares ventrais (1-2). O córtex foi modelado em quatro camadas. Dois pares de camadas de neurônios estrelados e de interneurônios GABAérgicos correspondendo às camadas $4 \mathrm{C} \alpha$ e 4B.

Em vista do fato de que o interesse deste trabalho é a investigação de fenômenos corticais, a primeira estrutura construída foi o córtex visual. A camada $4 \mathrm{C} \alpha$ foi modelada como duas matrizes de células. A primeira camada corresponde as células excitatórias. Estas células excitatórias podem ser classificadas de acordo com critérios morfológicos, em células estreladas e, de acordo com a classificação funcional apresentada na sessão anterior, como neurônios de disparo regular. A segunda camada corresponde as células inibitórias. Estas células inibitórias podem ser classificadas de acordo com critérios morfológicos, em células em cesto e funcionalmente, como neurônios de disparo rápido. 
Modelação do processamento visual primário em mamíferos - Capítulo III.

Caso se fosse construir a simulação para corresponder a $1 \mathrm{~mm}^{2}$ de córtex visual de primata, somente na camada $4 \mathrm{C} \alpha$ deveriam estar presentes, aproximadamente, 17.000 neurônios (somandose aí, neurônios corticais excitatórios e inibitórios) (O'KUSKY \& COLONIER, 1982). Isto tornaria a simulação inexequível. A situação seria, na verdade, ainda pior pois os fenômenos (sistemas colunares de seletividade à ocularidade e à orientação) que se pretende observar precisam de uma superfície cortical com extensão de aproximadamente $2 \mathrm{~mm}^{2}$ para serem adequadamente investigados. Em vista disso, é preciso estabelecer desde já uma escala de redução. A escala de redução utilizada foi 8:1. Aplicando-se o escalonamento, obtém-se um valor de densidade de neurônios igual a 4.250 neurônios em $2 \mathrm{~mm}^{2}$. A proporção de neurônios GABAérgicos nas diversas subcamadas da camada 4 varia em uma faixa entre 15\% e 25\% (PETERS et al., 1994). Adotou-se como valor base 20\%. Partindo disto, os neurônios excitatórios corresponderiam a 3.400 e os inibitórios a 850. Decidiu-se por modelar uma área quadrada de cortex. Para que os cálculos sejam facilitados, estes números foram arredondados para valores com raiz quadrada exata, respectivamente, 3.364 e 841 .

A camada 4B seguiu o mesmo molde em sua construção: duas camadas de células, uma camada de células excitatórias e outra de células inibitórias. Entretanto, o dimensionamento foi realizado utilizando-se os parâmetros adequados para esta camada. A densidade utilizada para o cálculo corresponde à soma das densidades das partes superior e inferior da camada 4B. Aplicando-se o escalonamento, obteve-se um valor de densidade de neurônios igual a 5.250 neurônios em 2 mm². Adotou-se 20\% como valor base para o cálculo da proporção de neurônios GABAérgicos. Com base nisto, os neurônios excitatórios corresponderiam a 4.200 e os inibitórios a 1.050. Para que os cálculos sejam facilitados, estes números foram arredondados para valores com raiz quadrada exata, respectivamente, 4.225 e 1.024 .

Determinadas as dimensões do cortex visual primário, o passo seguinte é a determinação das dimensões do NGL e das áreas de retina. A curva apresentada no gráfico da figura 2 (a curva mais espessa foi traçada utilizando o algoritmo de MALPELI et al. (1996)) permite observar que a densidade de células do canal M do NGL de primatas que inerva $1 \mathrm{~mm}^{2}$ de cortex varia de acordo com a excentricidade. Em torno de $20^{\circ}$ de excentricidade este número é, aproximadamente, 100. Como foi dito antes, este trabalho visa modelar, $2 \mathrm{~mm}^{2}$ de V1. Isto faria com que o número de células no NGL subisse para 200. Entretanto, deve-se ser coerente e aplicar á densidade de neurônios do NGL o mesmo fator de escalonamento aplicado à densidade de células em V1 (8:1). O resultado seria 25 células nas camadas do NGL. Este número é muito pequeno e ímpar. Além disso, 
Modelação do processamento visual primário em mamíferos - Capítulo III.

há duas camadas responsáveis pelo envio de sinais do canal magnocelular, uma recebe sinais do olho contralateral e a outra do olho ipsilateral. Devido ao padrão assimétrico dos terminais axonais talâmicos, optou-se por um valor que também tivesse raiz quadrada exata e par.

A retina foi modelada obedecendo ao mesmo dimensionamento do NGL. As retinas construídas correspondem a áreas nos olhos de um mamífero distantes da fóvea $20^{\circ}$. Isto significa que para compor o número de 200 células que inervam uma área de $2 \mathrm{~mm}^{2}$ seria necessário 100 células em cada lâmina do NGL e, em decorrência disto, em cada área correspondente às retinas contralateral e ipsilateral. A $20^{\circ}$ de excentricidade, a densidade de células ganglionares da retina é, aproximadamente, 25 células por grau ${ }^{2}$ segundo MALPELI et al. (1996) (Fig. 1) ${ }^{3}$ o que implica em duas áreas de $4^{\circ} \times 4^{\circ}$. Estas áreas estão voltadas para a mesma região do campo visual e portanto, recebem, em circunstâncias normais, a mesma estimulação visual. Para que seja desta forma, uma das áreas retinianas deve ser nasal e a outra temporal. Por conta disso, as densidades das células deveriam ser diferenciadas entre a área da retina referente ao olho esquerdo e a área da retina referente ao olho direito. Uma densidade média de células ganglionares que pudesse corresponder tanto à área da retina direita quanto à área da retina esquerda foi adotada.

O valor final foi o mesmo utilizado para o núcleo geniculado lateral, 64. Partindo-se do pressuposto que os neurônios de relê talâmicos são os únicos alvos dos axônios das células ganglionares da retina no NGL, ou seja, que aproximadamente nenhum axônio de célula ganglionar inerva nenhuma célula GABAérgica ou interneurônio talâmico, o NGL e a retina utilizam o mesmo dimensionamento (MALPELI et al., 1996). As retinas e as camadas do NGL foram construídos como camadas retangulares contendo 64 células. A principal diferença entre o modelo de retina e de NGL são os elementos que os compõem, como descrito na sessão anterior. Os neurônios de relê talâmico foram modelados de acordo com o formalismo apresentado no apêndice I ao passo que a modelação das células ganglionares da retina seguiu uma abordagem diferente (apresentada no apêndice II).

Por fim, foram construídas duas camadas de entrada correspondendo as retinas (64 células em cada uma), duas camadas de células correspondendo as duas lâminas mais ventrais do NGL (lâminas 1 e 2) cada uma recebendo contatos sinápticos de apenas uma das retinas em uma taxa unitária (64 células em cada uma) e quatro camadas corticais contendo células corticais excitatórias

É importante retificar que as densidades de neurônios utilizadas aqui são as densidades dos neurônios do canal M do NGL. A boa concordância entre a densidade total de neurônios do NGL e da retina em função da excentricidade é utilizada como evidência em favor da idéia de que a variação da densidade de neurônios em uma estrutura é boa preditora da densidade de neurônios na outra (MALPELI et al., 1996). 
Modelação do processamento visual primário em mamíferos - Capítulo III.

e inibitórias (3364 células excitatórias e 841 células inibitórias na camada $4 \mathrm{C} \alpha$ e 4225 células excitatórias e 1024 células inibitórias na camada 4B).
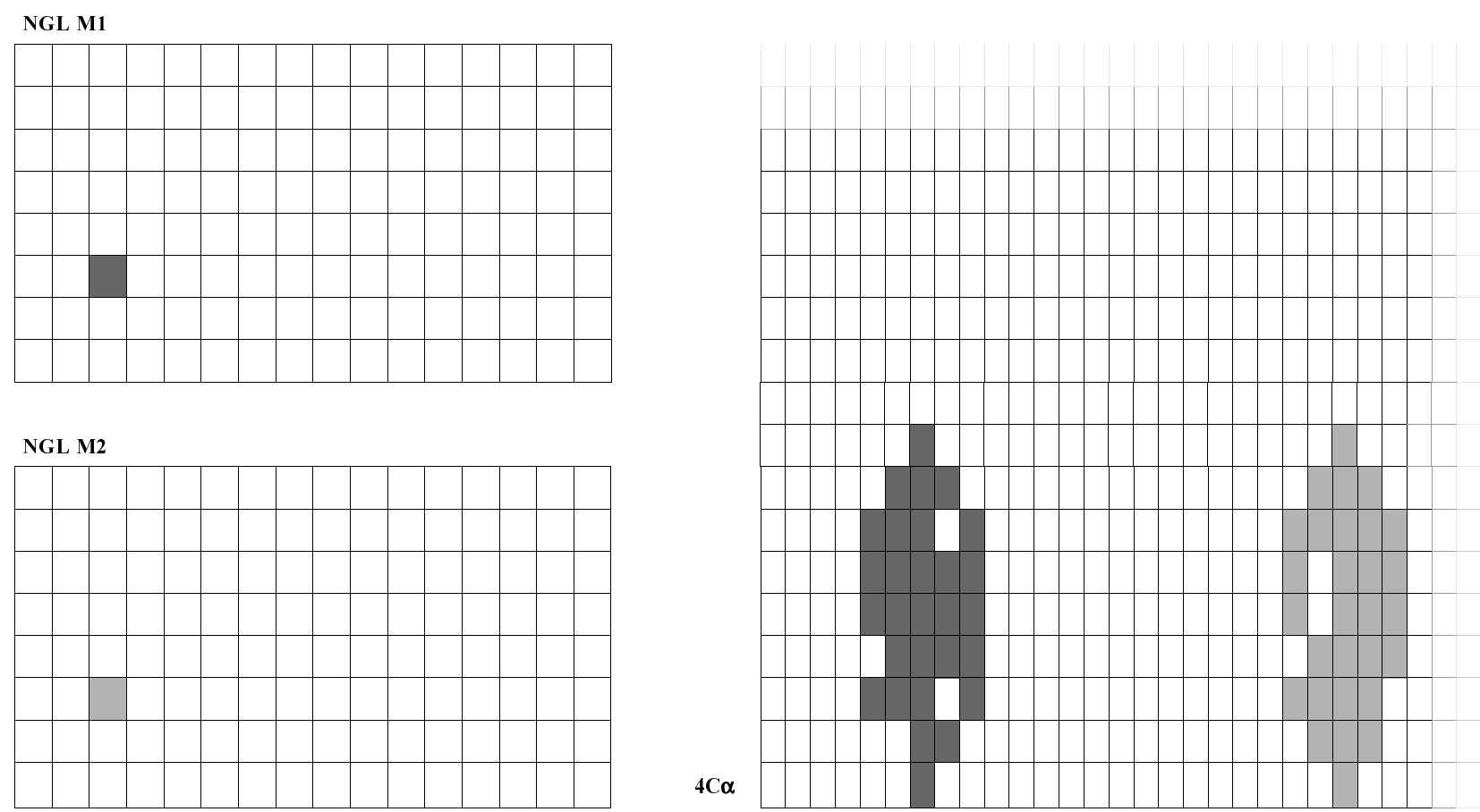

Figura 7. Representação esquemática do padrão de conexão entre o NGL e camada 4C $\alpha$ no modelo. À esquerda estão representadas as lâminas do NGL (1 e 2) e à direita uma área da camada 4C . No NGL M1 e M2 duas células estão destacadas em tonalidades diferentes e no córtex, na camada $4 C \alpha$, as áreas cobertas por seus terminais axonais estão também destacadas com as mesmas tonalidades. É possível observar que há uma diminuição na ocorrência de conexões nas margens destas áreas.

Os objetos que representam as células ganglionares da retina foram conectados aos neurônios de relê talâmico com uma taxa unitária. Como foi dito no capítulo anterior, estas estruturas têm semelhantes densidades de neurônios ao longo da excentricidade. Os contatos sinápticos foram realizados no compartimento 2 do modelo de neurônio de relê talâmico, que representa a porção mais distal do primeiro nível da árvore dendrítica onde está presente o receptor glutamatérgico do tipo AMPA (Fig. 4).

As células de relê talâmicas, por sua vez, projetam-se para as células estreladas da camada $4 \mathrm{C} \alpha$. Cada neurônio do tálamo projeta-se para as células estreladas contidas em uma área alongada de aproximadamente $0,3 \mathrm{~mm}^{2}$ de área com uma probabilidade que decai com a distância entre a célula estrelada e o centro da área coberta pelo terminal axonal talâmico (Fig. 7). Este padrão de conexão foi estabelecido observando-se a forma dos terminais axonais estudados por WU et al., (1998) e BLASDEL \& LUND, (1983). Há maior densidade de ramos no terminal axonal no centro da área coberta do que na periferia. Estas áreas alongadas estendem-se paralelas às colunas de dominância ocular. Os contatos sinápticos foram realizados no compartimento do modelo de célula excitatória. 
Modelação do processamento visual primário em mamíferos - Capítulo III.

que representa o primeiro nível da árvore dendrítica onde está presente o receptor glutamatérgico do tipo AMPA (Fig. 5).

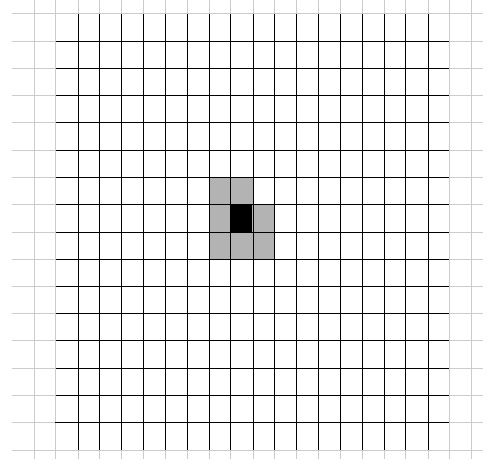

A) $e \rightarrow e$

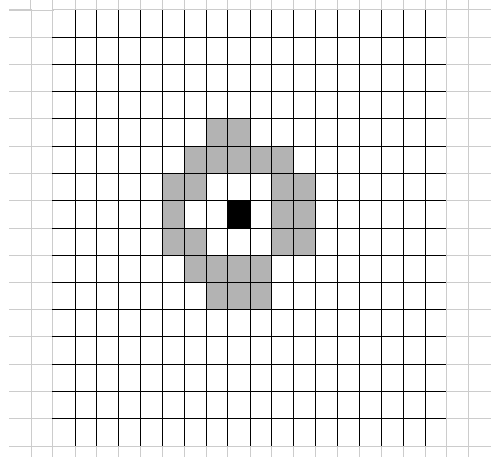

B) $e \rightarrow i$

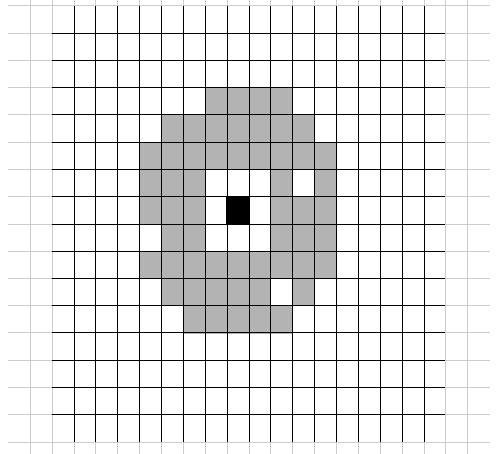

C) $i \rightarrow e$

Figura 8. Representação esquemática do padrão de conexão intralaminar na camada 4C $\alpha$ no modelo. A) As células estreladas conectam-se com as células estreladas $(e \rightarrow e)$ em uma região circular próxima com raio igual 0,1 mm. B) As células estreladas conectam-se com as células em cesto $(e \rightarrow i)$ em um anel cujo raio interno mede 0,15 mm e o raio externo mede 0,25 mm.C) As células em cesto conectam-se com as células estreladas $(i \rightarrow e)$ em um anel cujo raio interno mede $0,1 \mathrm{~mm}$ e o raio externo mede $0,3 \mathrm{~mm}$. Em todos os casos está apresentada apenas uma pequena área das camadas. Além disso, esta representação não obedece ao escalonamento apresentado discutido nesta sessão.

O padrão de conexão intralaminar de curto alcance buscou obedecer a evidência de que tanto os terminais axonais como árvores denríticas das células corticais cruzam os limites das colunas corticais de forma indiscriminada. Cada célula estrelada da camada $4 \mathrm{C} \alpha$ projeta-se para todas as células estreladas desta camada em uma vizinhança circular com raio de $0,1 \mathrm{~mm}$ com uma probabilidade constante e igual a 0,9 e para todas as células inibitórias em uma região em forma de anel cujo raio interno mede $0,15 \mathrm{~mm}$ e o raio externo mede $0,25 \mathrm{~mm}$ com uma probabilidade constante igual a 0,7 . As células em cesto conectam-se com todas as células estreladas em uma região em forma de anel cujo raio interno mede $0,1 \mathrm{~mm}$ e o raio externo mede $0,3 \mathrm{~mm}$ com uma probabilidade constante e igual a 0,8 . Este padrão está descrito na figura 8 . 
Modelação do processamento visual primário em mamíferos - Capítulo III.

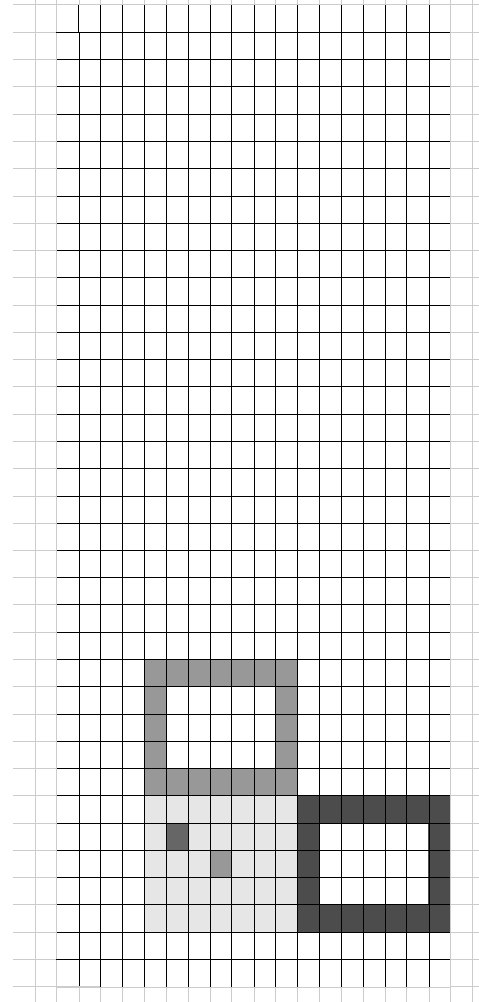

$4 B$

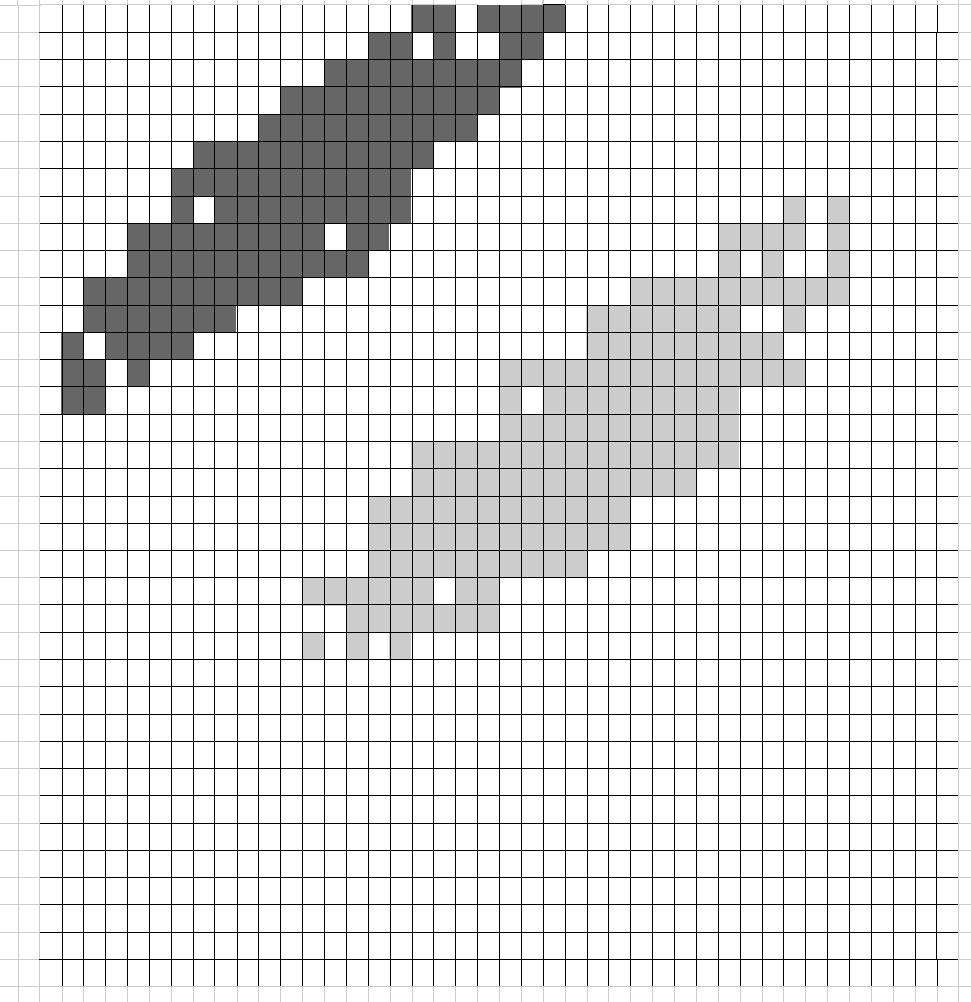

$4 C \alpha$

Figura 9. Representação esquemática do padrão de conexão interlaminar entre a camada 4 C $\alpha$ e a camada $4 B$ no modelo. Há três áreas destacadas na camada 4B. Uma destas áreas é composta por neurônios que respondem a estímulos com $45^{\circ}$ de orientação. Nesta região, há dois neurônios destacados. Os neurônios que os inervam presentes na camada $4 C \alpha$ também estão destacados com a mesmas tonalidades. O Padrão de conexão mantém-se topográfico. As áreas adjacentes, na camada $4 B$ são compostas por neurônios que respondem seletivamente a orientações diferentes mas próximas de $45^{\circ}$.

$\mathrm{Na}$ célula estrelada, os contatos sinápticos excitatórios foram realizados no compartimento do modelo de célula excitatória que representa o primeiro nível da árvore dendrítica que contem NMDA e os inibitórios no compartimento do modelo que representa o primeiro nível da árvore dendrítica das células excitatórias que contém GABA (Fig. 5). Na célula em cesto, os contatos sinápticos excitatórios foram realizados no compartimento do modelo de célula excitatória que representa o segundo nível da árvore dendrítica que contem NMDA (Fig. 6).

Desta forma, o padrão de conexão intralaminar é homogêneo ao longo das camadas não havendo maior probabilidade de ocorrência de conexões entre neurônios pertencentes a uma mesma coluna cortical ou colunas corticais com propriedades funcionais semelhantes. Na verdade, a única tendência fornecida para o surgimento da seletividade à orientação no modelo é alinhamento dos campos receptivos das células da camada 4B. Células que recebem inervação de neurônios da camada $4 \mathrm{C} \alpha$ com orientação semelhante estão em regiões próximas na camada 4B. Estas regiões estão organizadas de maneira regular como pode ser visto na figura 10. 
Modelação do processamento visual primário em mamíferos - Capítulo III.

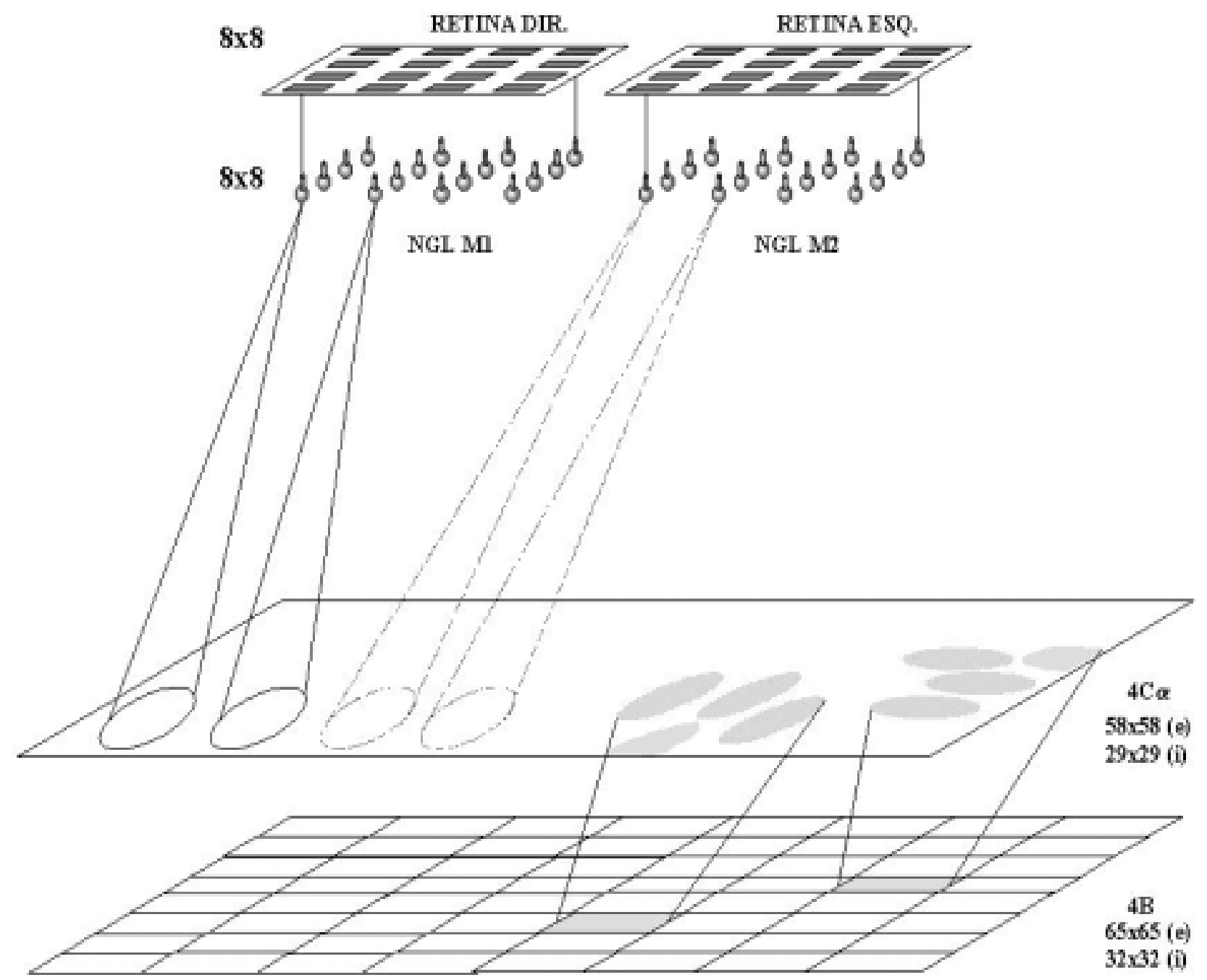

Figura 10. Representação esquemática do padrão de conexão entre as estruturas no modelo. As retinas estão apresentadas compostas por objetos capazes de gerar disparos de acordo com o método descrito no apêndice II. Estão conectadas com o NGL de forma topográfica com uma relação 1:1. Tanto a retina quanto o NGL estão representadas por matrizes com o mesmo dimensionamento do modelo. As demais estruturas estão representadas por áreas retangulares. A camada $4 C \alpha$ recebe conexões do NGL de forma que as entradas originadas das áreas que representam o olho direito e o olho esquerdo permaneçam segregadas. Os terminais axonais têm forma elíptica e têm seu principal eixo paralelo às áreas monoculares desta camada. O padrão de conexão entre a camada $4 C \alpha$ e a camada $4 B$ foi organizado de forma topográfica e uma tendência a orientação foi estabelecida. Esta estratégia, entretanto, promoveu a existência de células cujos campos receptivos foram cortados devido à localização próxima da borda da matriz.

O padrão de conexão entre a camada $4 \mathrm{C} \alpha$ e a camada 4B foi estabelecido da seguinte maneira. Os neurônios excitatórios da camada $4 \mathrm{C} \alpha$ projetam-se para a camada 4B de uma forma essencialmente convergente. O campo receptivo dos neurônios da camada 4B corresponde a uma região alongada em uma dada orientação em que as células estreladas da camada $4 \mathrm{C} \alpha$ estão alinhadas (Fig. 9; Fig. 10). A probabilidade de ocorrência de conexões decai com a distância entre a célula pré-sináptica e o centro do campo receptivo. Obedecendo a um padrão topográfico, as células que compõem uma coluna de seletividade à orientação recebem um padrão de inervação que fornece a tendência inicial para o surgimento de seletividade. Em uma coluna de dominância ocular na 
Modelação do processamento visual primário em mamíferos - Capítulo III.

camada 4B existem 16 conjuntos de neurônios que apresentam campos receptivos com diferentes orientações. As orientações variam de $0^{\circ}$ até $168,75^{\circ} \mathrm{em}$ intervalos de $11,25^{\circ}$. Naturalmente, na implementação, deste padrão de conexão não foram incluídas as descontinuidades discutidas no Capítulo II. As regiões são essencialmente lineares e as CDOs contêm em sua extensão CSOs suficientes para contemplar populações de neurônios seletivos à estímulos com orientações variando de $0^{\circ}$ até $180^{\circ}$.

A camada 4B tem suas conexões intralaminares organizadas de forma semelhante à camada 4C $\alpha$. Entretanto, as células em cesto conectam-se a células estreladas em uma área cujo raio interno é igual $0,1 \mathrm{~mm}$ e o raio externo é igual a $0,5 \mathrm{~mm}$. 
Modelação do processamento visual primário em mamíferos - Capítulo IV.

\section{Capítulo IV}

\section{Resultados.}

O modelo de sistema visual primário descrito no capítulo anterior foi implementado utilizando o neurosimulador GENESIS 2.2. (versão beta-21/12/200) (BOWER \& BEEMAN, 1997) rodando em sistema LINUX (kernel 2.2.15). Os cenários ${ }^{4}$ foram rodados em um microcomputador (PC) com processador Pentium Intel III ${ }^{\mathrm{TM}}$, $500 \mathrm{MHz}$, com $192 \mathrm{Mb}$. de memória RAM. O passo de integração utilizado para a resolução das equações diferenciais foi $5 \times 10^{-5} \mathrm{seg}$. Dois tipos de dados foram registrados: a variação do potencial de membrana e os tempos de ocorrência de disparos. A variação do potencial de membrana foi registrada de 10 em 10 passos de simulação. Os tempos de ocorrência de disparos foram registrados continuamente.

Os neurônios foram submetidos a protocolos com o intuito de investigar suas propriedades eletrofisiológicas. A rede foi submetida a protocolos para investigar as propriedades dos campos receptivos dos neurônios corticais que a compõem. No caso dos neurônios individuais, a variação do potencial de membrana foi utilizada para averiguar a forma dos potenciais de ação, os tempos de ocorrência de disparos foram utilizados para gerar curvas $f-i$ (frequência por injeção de corrente) e intervalo entre potenciais de ação (IPA) por intervalo. No caso da rede, a variação no potencial de membrana foi utilizada para investigar as propriedades temporais dos campos receptivos e os tempos de ocorrência dos potenciais de ação foram utilizados para construir as curvas de sintonia para classes de estímulo.

\section{Neurônios.}

Muitos modelos compartimentais de neurônios são desenvolvidos partindo-se de uma descrição geométrica acurada dos neurônios originais. Em seguida, mantendo-se as constantes temporal e espacial, a geometria destes neurônios é colapsada até que um modelo composto de apenas alguns compartimentos seja estabilizado. Este modelo deve apresentar comportamentos semelhantes aos dos neurônios originais. A avaliação do comportamento de modelos de neurônios tem-se baseado quase que exclusivamente no padrão temporal de seus potenciais de ação quando submetidos a injeção elétrica ou ativação sináptica.

\footnotetext{
O termo 'cenário' é utilizado aqui para definir cada ocasião em que uma simulação é carregada. Por exemplo, mesmo que não haja alteração explícita no algoritmo responsável pela montagem do padrão de conexão, o campo receptivo dos neurônios não é exatamente o mesmo já que vários parâmetros são estabelecidos com um caráter probabilístico.
} 
Modelação do processamento visual primário em mamíferos - Capítulo IV.

As seguintes variáveis foram utilizadas para avaliar o comportamento dos modelos reduzidos de neurônio: as características dos potenciais de ação individuais (1), a relação frequência de disparo por corrente injetada (2). O comportamento dos neurônios individuais submetidos a valores constantes de corrente foram utilizados na construção de curvas de disparo por injeção de corrente $(f-i)$. Estas curvas mostram os perfis de disparo dos neurônios prototípicos. A seguir, estas curvas são apresentadas para a célula de relê talâmico, a célula estrelada, a célula em cesto (interneurônio GABAérgico). As curvas $f$ - $i$ foram calculadas a partir do primeiro intervalo entre potenciais de ação (1/1IPA) e a partir de uma média dos IPAs durante os últimos 0,5 seg de uma estimulação com duração de $2 \mathrm{seg}$. Além das curvas de frequência de disparo por injeção de corrente, também estão descritas as formas dos potenciais de ação quando as células são submetidas a injeção de corrente no valor do limiar.

As propriedades quantitativas dos potenciais de ação apresentadas na tabela 5, 6 e 7 foram investigadas de acordo com o seguinte protocolo experimental. Os neurônios foram submetidos a uma corrente despolarizadora com valores iguais ao limiar de disparo. Este limiar é definido como o valor de corrente capaz de gerar pelo menos um potencial de ação mesmo que depois de um período de latência longo (a corrente foi mantida por 0,2 seg). Esta corrente recebe o nome de corrente reóbase. A amplitude e duração deste potencial de ação foi medida e comparada com os dados apresentados na literatura (tabelas 5, 6 e 7). A amplitude corresponde ao valor absoluto da diferença entre o pico do potencial de ação e o potencial de repouso. A duração corresponde ao intervalo de tempo decorrido entre o momento em que o valor do potencial de membrana se iguala à metade do valor de amplitude do potencial de ação na fase de despolarização e o momento em que o potencial de membrana se iguala ao mesmo valor durante a fase de hiperpolarização. Entretanto, há uma grande variação nos protocolos utilizados para fazer estas medidas (por exemplo, a duração da injeção de corrente, o método para medir a amplitude do potencial de ação pode tomar como valor mínimo o menor potencial de membrana encontrado no complexo de hiperpolarização correspondente ao período refratário absoluto) e isto, de alguma forma, pode ter contribuído para a semelhança ou dessemelhança entre os dados dos neurônios reais e simulados.

As curvas $f-i$ foram calculadas submetendo-se os neurônios a injeção de corrente constante por 2 seg para valores de corrente que variam desde 0 até $2 \times 10^{-9} \mathrm{~A}$. em intervalos de $0,1 \times 10^{-9} \mathrm{~A}$. O traço azul é a interpolação resultante dos pontos correspondentes às relações de frequência por injeção de corrente. Em todos os gráficos há duas curvas $f-i$. A primeira é calculada utilizando-se apenas o primeiro IPA (1/1-IPA), a segunda, utiliza uma média dos IPAs dos últimos 0,5 seg. Aqueles neurônios que apresentam adaptação da frequência de disparo geram curvas sensivelmente 
Modelação do processamento visual primário em mamíferos - Capítulo IV.

diferentes nestes dois métodos. Apenas os valores de corrente que puderam gerar frequências que se mantivessem por mais de 1,5 seg foram utilizados para construir as curvas. Mais uma vez é importante que se faça uma ressalva. Os protocolos experimentais também variam muito na investigação das propriedades de disparo repetido dos neurônios. Muitos utilizam faixas de valores de corrente que se iniciam com valores capazes de gerar apenas um disparo e seguem testando valores bastante altos superiores a $3 \times 10^{-9}$ A. Segundo AZOUZ et al. (1997), os neurônios corticais in vivo não operam em faixas de integração de corrente superiores a $0,6 \times 10^{-9} \mathrm{~A}$. Em vista disto, escolhemos valores pertencentes a faixa que vai de 0 até $2 \times 10^{-9} \mathrm{~A}$. Apesar disto, é possível perceber por meio da ausência de saturação nas curvas $f$-i que alguns dos neurônios responderiam a valores superiores de corrente.

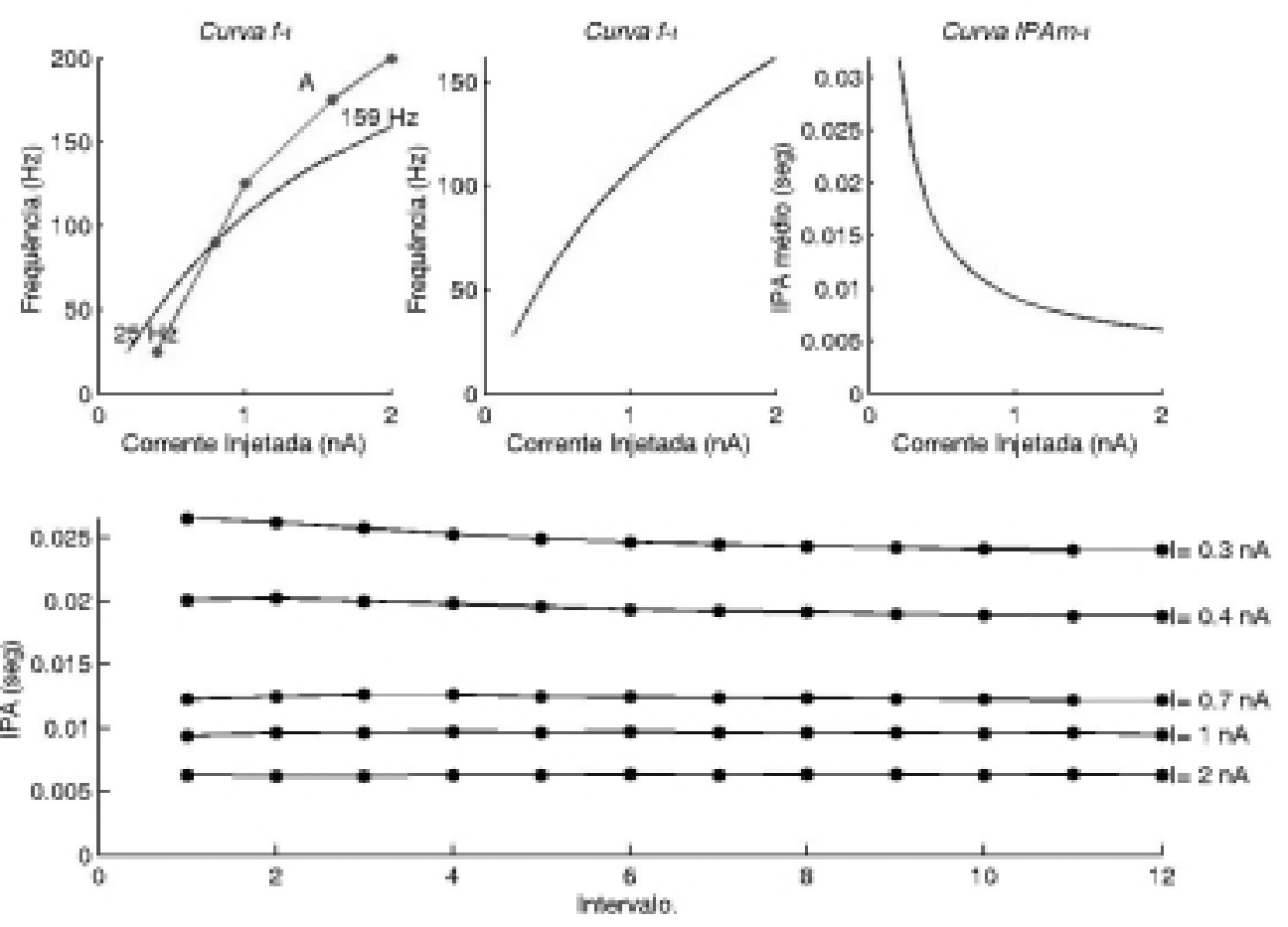

Figura 11. Padrão e disparo repetido da célula de relê talâmica. A frequência apresentada na primeira curva f-i foi calculada utilizando-se o primeiro intervalo entre potenciais de ação $\left(1 / 1^{\circ} I P A\right)$. Ao primeiro gráfico foi acrescentada uma curva f-i retirada de uma investigação eletrofisiológica sobre as propriedades de neurônios de relê talâmicos (ZHAN et al., 1999). A frequência apresentada na segunda curva f-i corresponde a uma média dos últimos 0.5 seg de um total de 2 seg de estimulação. A curva IPAm-i apresenta a média dos IPAs para cada valor de corrente. O terceiro gráfico IPA-intervalo apresenta a variação dos IPAs por intervalo para 4 valores de corrente injetada. Não há evidência de adaptação para nenhum valor de corrente.

A curva $f-i$ para as células de relê talâmicas modeladas é apresentada na figura 11. A frequência de disparo observada aqui é inferior a frequência de disparo do NDRes (Fig. 14) e do NDRas (Fig. 16). E, naturalmente, o IPA médio é superior para todas as correntes. Ao invés de adaptação pode-se observar uma pequena aceleração na frequência dos potenciais de ação. Estes resultados foram 
Modelação do processamento visual primário em mamíferos - Capítulo IV.
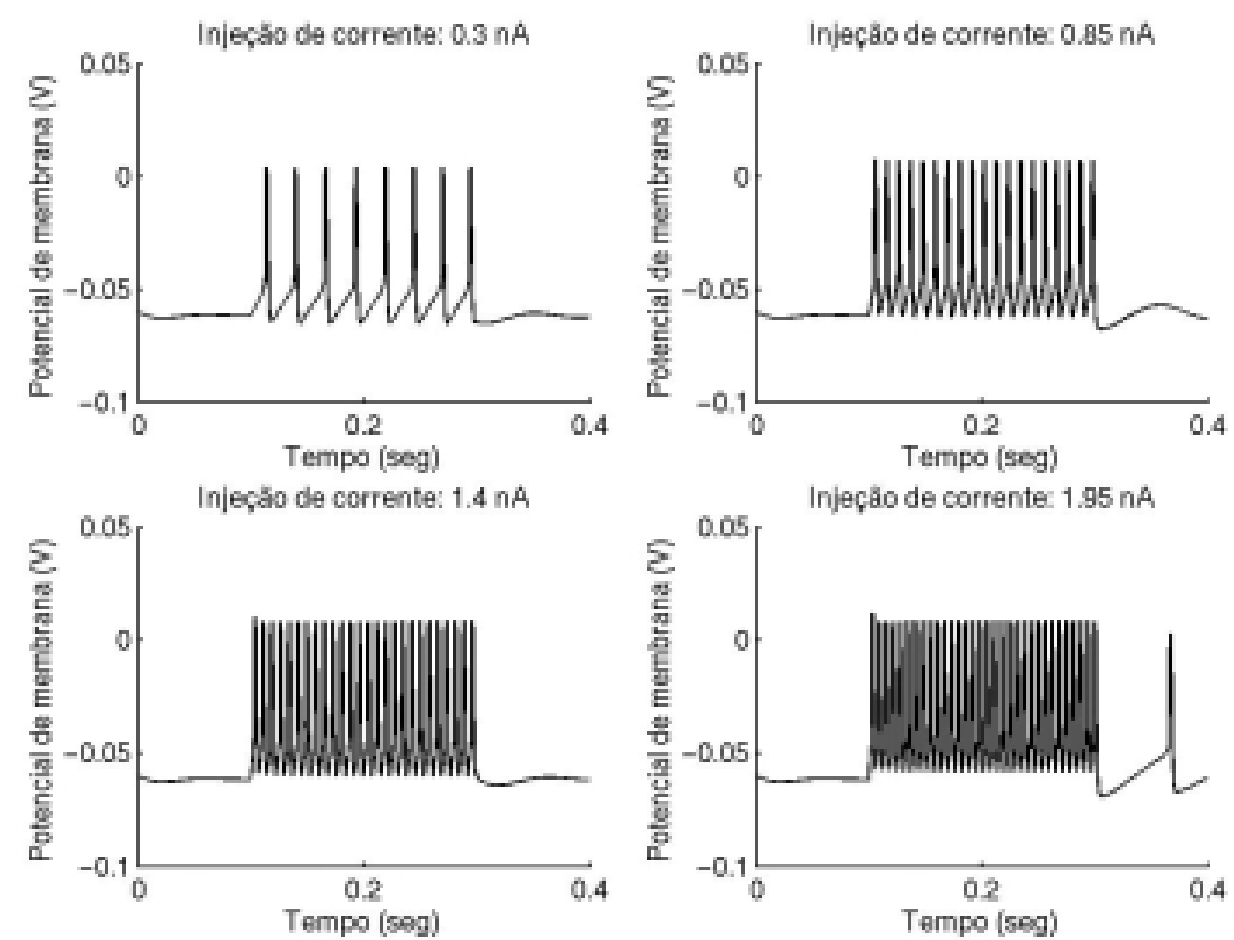

Figura 12. Resposta dos neurônios de relê talâmicos a diferentes valores de corrente. Os neurônios modelados foram submetidos ao seguinte padrão de estimulação: durante 0,1 seg os neurônios não são submetidos a injeção de corrente, durante os 0,2 seg seguintes, o neurônio é submetido a uma injeção de corrente (os valores estão assinalados no alto de cada gráfico). Em seguida, a injeção de corrente é interrompida. Pode-se perceber que o neurônio possui um potencial e repouso estável e que mediante valores de injeção de corrente sucessivamente aumentados, sua frequência de disparo é também aumentada. Após cessada a estimulação o neurônio retorna ao seu potencial de repouso. No último gráfico $\left(I=1,95 \times 10^{-9} \mathrm{~A}\right)$, a injeção de corrente é interrompida no momento em que o neurônio está sendo repolarizado e ocorre a ativação do canal de cálcio de baixo limiar que leva a geração de um potencial de ação lento $e$ em seu topo, um potencial de ação convencional.

obtidos mantendo-se o potencial de repouso da célula de relê talâmico próximo a $-0,06 \mathrm{~V}$. Os padrões de disparo para as células de relê talâmicas podem ser também observadas por meio da variação do potencial de membrana na figura 12. Pode-se perceber que a amplitude dos disparos é menor que a amplitude apresentada para as células corticais. Esta característica dos neurônios de relê talâmicos está descrita na literatura (McCORMICK \& FEESER, 1990). Ao primeiro gráfico foi acrescentada a curva $f-i$ (A) apresentada no gráfico C (Fig. 3.) de ZHAN et al. (1999). Neste estudo estão apresentadas algumas curvas $f-i$ de neurônios do NGL de gatos. Os valores de corrente testados neste estudo não correspondem aos valores testados na validação dos modelos de neurônio deste trabalho. A inclinação da curva apresentada é inferior àquela retirada da literatura. Isto pode se dever a não inclusão de canais de cálcio de alto limiar nos modelos de célula talâmica. Estes canais estão presentes em células do NGL e têm um pequeno papel na excitação destas células mas não foram incluídos neste modelo (ZHAN et al., 1999). Entretanto, pode se perceber que há alguma 
Modelação do processamento visual primário em mamíferos - Capítulo IV.

semelhança entre as curvas como, por exemplo, valores de frequência de disparo mínimos próximas.

Tab. 5. Célula de relê talâmica. Os parâmetros quantitativos referentes à forma do potencial de ação foram medidos submetendo-se o neurônio modelado a correntes exatamente iguais ao limiar de disparo de potenciais de ação por um período de 0,2 seg.

\begin{tabular}{l|l|l|l|l}
\hline \multicolumn{1}{c|}{ Grandeza } & \multicolumn{1}{c|}{ Valor } & \multicolumn{1}{c|}{ Referência } & \multicolumn{1}{c|}{ Valor } & \multicolumn{1}{c}{ Referência } \\
\hline Amplitude do disparo. & $0,067 \mathrm{~V}$. & $\begin{array}{l}\text { (BLOOMFIELD et al., } \\
1987)\end{array}$ & $0,062 \mathrm{~V}$. & modelo \\
\hline $\begin{array}{l}\text { Duração do disparo } \\
\text { em } 1 / 2 \text { amplitude. }\end{array}$ & -- & - & $0,00086 \mathrm{seg}$. & modelo \\
\hline
\end{tabular}

Os potenciais de ação são gerados pelos canais de sódio transiente presentes neste modelo de célula talâmica. Entretanto, é a presença de canais de cálcio de baixo limiar que gera os disparos em rajada observados na figura 13. A variação do potencial de membrana descrita na figura 13 foi obtida mantendo-se o potencial de membrana estável e próximo a -0,06 V. e injetando-se uma corrente hiperpolarizadora. O gráfico apresenta a variação do potencial de membrana para uma injeção de corrente no valor $-0,3 \times 10^{-9} \mathrm{~A}$. Apesar dos experimentos para estudo de mapas corticais e de sistemas colunares não serem realizados durante períodos em que o animal está com o nível de alerta diminuído, a capacidade do neurônio de gerar disparos em rajada depõe a favor de sua plausibilidade biológica.

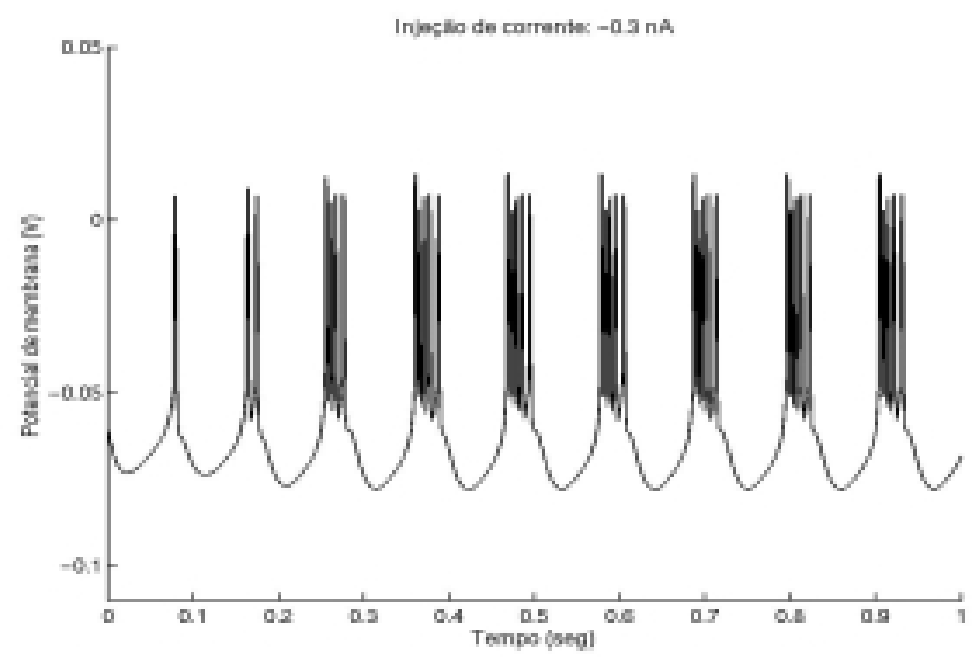

Figura 13. Disparos em rajada na célula de relê talâmica. A variação do potencial de membrana apresentada nesta figura foi obtida mantendo-se o potencial de membrana estável e próximo a -0,06 V. e injetando valores de corrente hiperpolarizadoras. O gráfico apresenta a variação do potencial de membrana para uma injeção de corrente no valor $-0,3 \times 10^{-9} \mathrm{~A}$. Pode-se perceber a ocorrência de diversos disparos em rajada.

Além de ser uma classe de neurônios em que a taxa de disparos é sensivelmente menor do que a taxa de disparos dos NDRas, os NDRes apresentam uma outra característica: adaptação na 
Modelação do processamento visual primário em mamíferos - Capítulo IV.

frequência de disparos. Na figura 14, é possível perceber uma adaptação de frequência para todos os valores de corrente injetados na célula, especialmente, valores baixos. Este aspecto é característico de NDRes (McCORMICK et al., 1985). Esta adaptação provocada pela presença do canal iônico conhecido como potássio ativado por cálcio $\left(K_{A H P}\right)$. Este canal é independente de voltagem. Seu comportamento está relacionado com a concentração intracelular de cálcio. Quando ocorrem potenciais de ação, o cálcio entra na célula e ativa esta corrente que diminui o efeito da corrente despolarizadora injetada por meio de eletrodo ou por ativação de canal sináptico. Além disso, este canal é responsável pela presença de complexos de hiperpolarização que se seguem ao período de repolarização do potencial de ação. Pode se perceber este efeito por meio do exame da figura 15. Após o período de estimulação, os NDRes demoram mais tempo para retornar ao potencial de repouso. A ausência deste comportamento pode ser constatada no NDRa cujo potencial de membrana retorna rapidamente ao repouso assim que cessada a estimulação (Fig. 17).

Ao primeiro gráfico da figura 14 , foram acrescentadas duas curvas resultantes de investigações experimentais das propriedades eletrofisiológicas de neurônios reais (McCORMICK et al., 1985). Pode-se perceber a semelhança entre as curvas. Além disso, suas freqüências máximas e mínimas aglutinam-se em torno de valores próximos. Neste caso em que ocorre uma adaptação flagrante é possível notar também a diferença entre as curvas do primeiro gráfico e do segundo gráfico. Isto se deve ao fato de que a forma utilizada para calcular a curva $f-i$ no primeiro gráfico foi diferente da utilizada no segundo gráfico (Fig. 14). Em vista deste fato pode-se perceber que as frequências observadas no primeiro gráfico são superiores àquelas observadas no segundo. O primeiro gráfico utiliza o $1^{\circ}$ IPA para calcular a frequência enquanto o segundo usa uma média dos últimos 0,5 seg.

Tab. 6. Célula estrelada da camada 4. Os parâmetros quantitativos referentes à forma do potencial de ação foram medidos submetendo-se o neurônio modelado a correntes exatamente iguais ao limiar de disparo de potenciais de ação por um período de 0,2 seg.

\begin{tabular}{l|l|l|l|l}
\hline \multicolumn{1}{c|}{ Grandeza } & \multicolumn{1}{c|}{ Valor } & \multicolumn{1}{c|}{ Referência } & \multicolumn{1}{c}{ Valor } & \multicolumn{1}{c}{ Referência } \\
\hline Amplitude do disparo. & $0,0952 \pm 0,0095 \mathrm{~V}$. & $\begin{array}{l}\text { (McCORMICK et al., } \\
1985)\end{array}$ & $0,1050 \mathrm{~V}$. & modelo \\
\hline $\begin{array}{l}\text { Duração do disparo } \\
\text { em } 1 / 2 \text { amplitude. }\end{array}$ & $\begin{array}{l}0,00080 \pm 0,00018 \\
\text { seg. }\end{array}$ & $\begin{array}{l}\text { (McCORMICK et al., } \\
1985)\end{array}$ & $0,00073 \mathrm{seg}$. & modelo \\
\hline
\end{tabular}


Modelação do processamento visual primário em mamíferos - Capítulo IV.
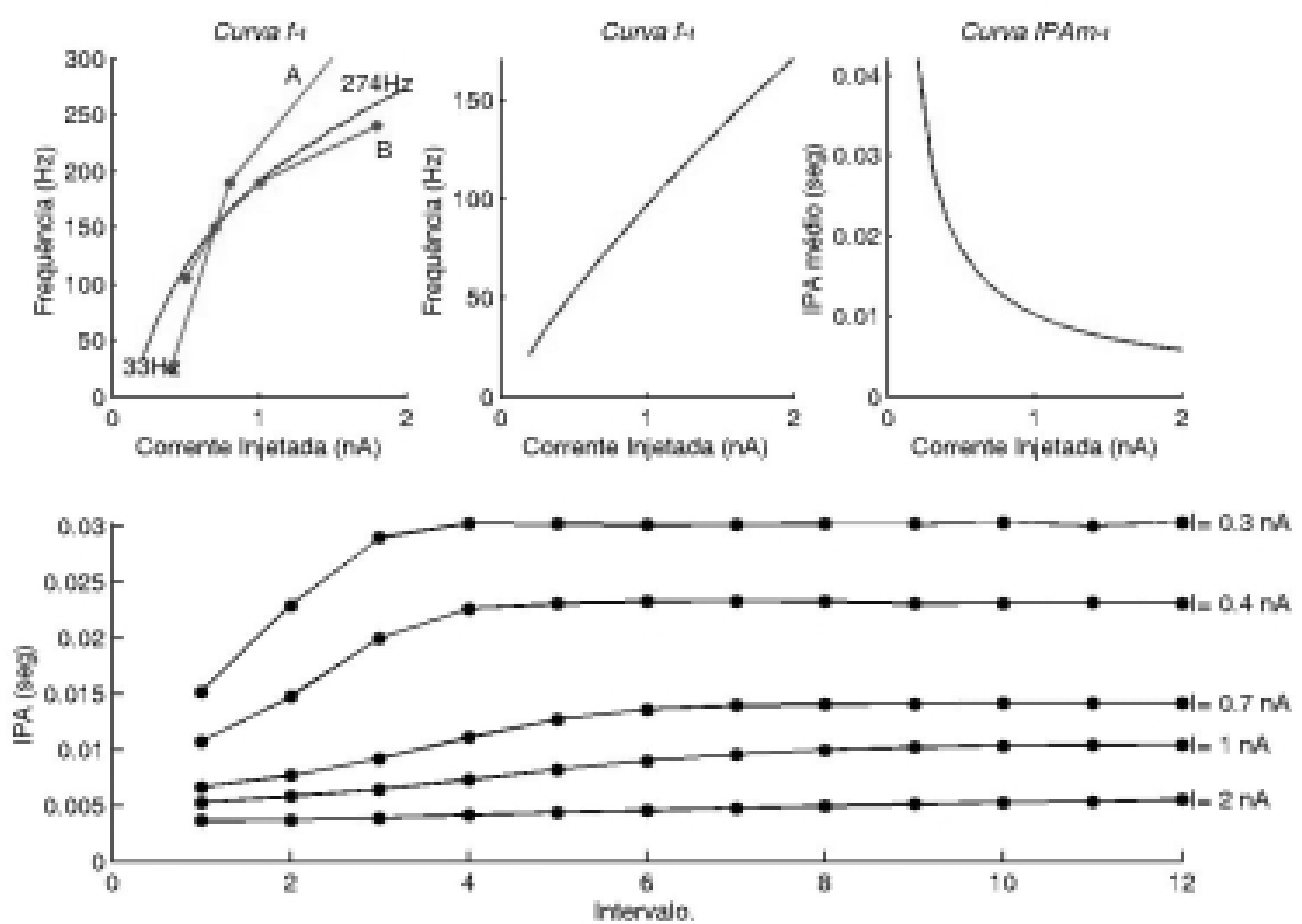

Figura 14. Padrão de disparo repetido da célula estrelada da camada 4. A frequência apresentada na primeira curva f-i foi calculada através do primeiro intervalo entre potenciais de ação (1/1IPA). A frequência apresentada na segunda curva f-i corresponde a média da duração dos intervalos entre potenciais de ação durante os últimos 0,5 seg de um total de 2 seg de estimulação. Comparando-se a primeira e a segunda curva pode-se perceber uma diferença marcante entre elas que se deve a adaptação flagrante presente nesta classe de neurônios. $A$ curva IPAm-i apresenta a média dos IPAs para cada valor de corrente. O terceiro gráfico IPAintervalo apresenta a variação dos IPAs por intervalo para 4 valores de corrente injectada. Foram acrescentadas ao primeiro gráfico duas curvas $f-i$ ( $A$ e B) retiradas de McCORMICK et al. (1985) associadas a neurônios piramidais classificados como NDRes.

O potencial de membrana da célula modelada foi medido para diferentes intensidades de corrente. É possível perceber a adaptação da frequência de disparos característica dos NDRes, e o aumento da frequência de disparos de acordo com o aumento na intensidade de corrente (Fig. 15). A adaptação pode ser percebida em todas as intensidades de corrente mas é mais flagrante para baixas intensidades de corrente pouco superiores ao limiar de disparo, por exemplo $0,3 \times 10^{-9}$ A. (Fig. 14; Fig. 15). A frequência de disparo mostra-se estabilizada 0,05 seg após o início da estimulação em boa concordância com registros experimentais (McCORMICK et al., 1985).

A figura 16 apresenta a curva de frequência de disparo por injeção de corrente para os interneurônios GABAérgicos modelados, células em cesto da camada 4 do modelo de córtex visual de mamíferos. A frequência de disparo observada aqui é superior a frequência de disparo do NDRes. E, naturalmente, o IPA médio é inferior. Pode-se perceber a ausência de adaptação pronunciada para os 4 valores de corrente apresentadas no gráfico que descreve a variação do IPA por intervalo. Ao primeiro gráfico foi acrescentada a curva apresentada no gráfico D (Fig. 1) de 
Modelação do processamento visual primário em mamíferos - Capítulo IV.
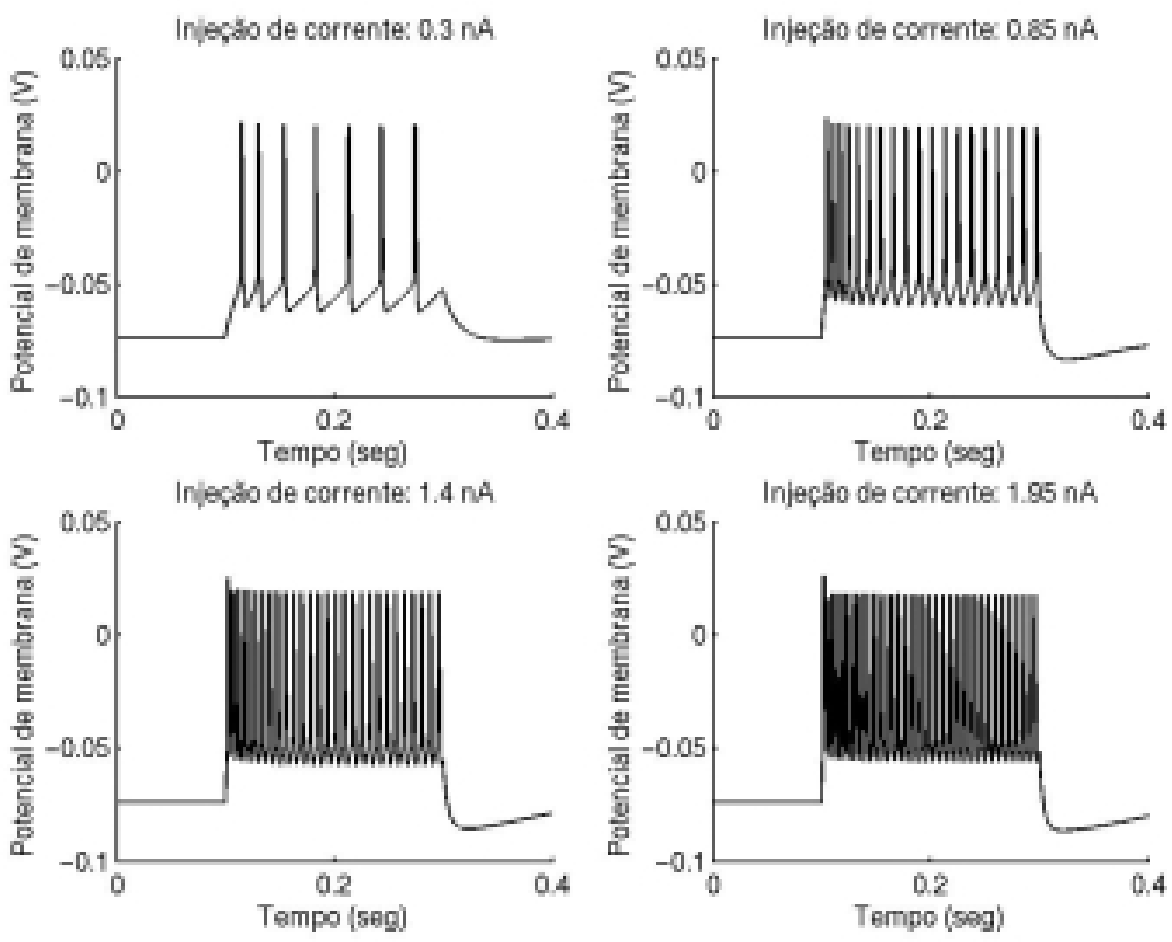

Figura 15. Resposta da célula estrelada da camada 4 a diferentes valores de corrente. Os neurônios modelados foram submetidos ao seguinte padrão de estimulação: durante 0,1 seg os neurônios não são submetidos a injeção de corrente, durante os 0,2 seg seguintes, o neurônio é submetido a uma injeção de corrente (os valores estão assinalados no alto de cada gráfico). Em seguida, a injeção de corrente é interrompida. Pode-se perceber que o neurônio possui um potencial e repouso estável e que mediante valores de injeção de corrente sucessivamente aumentados, sua frequência de disparo é também aumentada. Após cessada a estimulação o neurônio retorna ao seu potencial de repouso lentamente.

ERISIR et al. (1999) (A) e a curva apresentada no gráfico C (Fig. 6) de McCORMICK et al. (1985) (B). Há uma pequena tendência para adaptação para pequeno valores de corrente que é, em seguida, substituída por uma aceleração também pequena. Esta característica foi encontrada por AZOUZ et al. (1997) e está destacada por uma seta no gráfico de IPA-intervalo (Fig. 16).

Tab. 7. Célula em cesto. Os parâmetros quantitativos referentes à forma do potencial de ação foram medidos submetendo-se o neurônio modelado a correntes exatamente iguais ao limiar de disparo de potenciais de ação por um período de 0,2 seg.

\begin{tabular}{l|l|l|l|l}
\hline \multicolumn{1}{c|}{ Grandeza } & \multicolumn{1}{c|}{ Valor } & \multicolumn{1}{c|}{ Referência } & \multicolumn{1}{c|}{ Valor } & \multicolumn{1}{c}{ Referência } \\
\hline Amplitude do disparo. & $0,067 \mathrm{~V}$. & $\begin{array}{l}\text { (McCORMICK et al., } \\
1985)\end{array}$ & $0,079 \mathrm{~V}$. & modelo \\
\hline $\begin{array}{l}\text { Duração do disparo } \\
\text { em } 1 / 2 \text { amplitude. }\end{array}$ & $\begin{array}{l}0,00032 \pm 0,00010 \\
\text { seg. }\end{array}$ & $\begin{array}{l}\text { (McCORMICK et al., } \\
1985)\end{array}$ & $0,00037 \mathrm{seg}$. & modelo \\
\hline $\begin{array}{l}\text { Duração do disparo } \\
\text { em } 1 / 2 \text { amplitude. }\end{array}$ & $\begin{array}{l}0,00032 \pm 0,00006 \\
\text { seg. }\end{array}$ & (AZOUZ, et al., 1997) & & \\
\hline
\end{tabular}


Modelação do processamento visual primário em mamíferos - Capítulo IV.
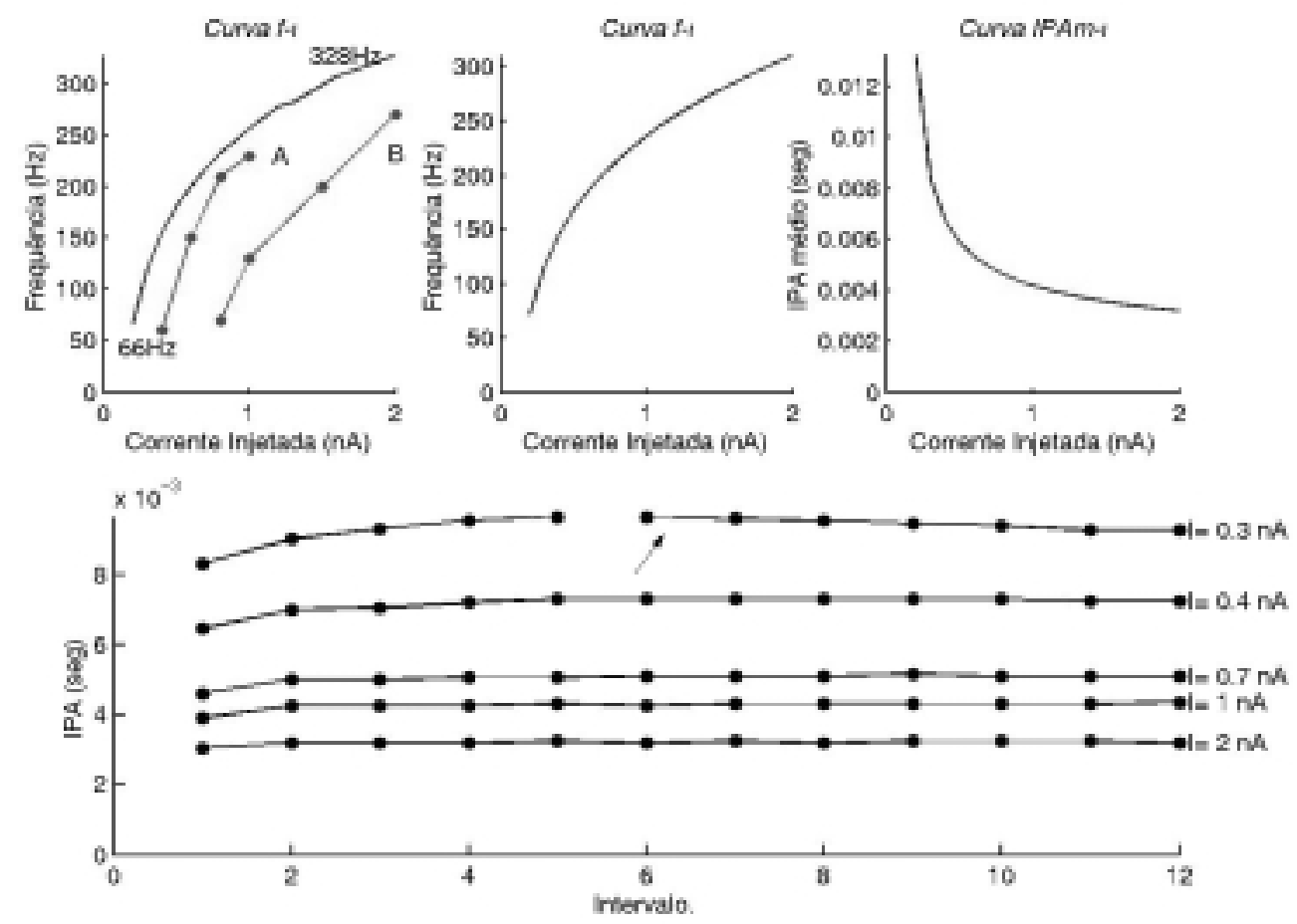

Figura 16. Padrão de disparo repetido da célula em cesto da camada 4. A frequência apresentada na primeira curva f-i foi calculada através do primeiro intervalo entre potenciais de ação (1/1IPA). A frequência apresentada na segunda curva f-i corresponde a média da duração dos intervalos entre potenciais de ação durante os últimos $0,5 \mathrm{seg}$ de um total de 2 seg de estimulação. A curva IPAm-i apresenta a média dos IPAs para cada valor de corrente. O terceiro gráfico IPA-intervalo apresenta a variação dos IPAs por intervalo para 4 valores de corrente injetada. A pequena seta neste gráfico chama a atenção para a pequena adaptação seguida por aceleração ambas características de interneurônios GABAérgicos de V1 (AZOUZ, et al., 1997). Ao primeiro gráfico foram acrescentadas curvas f-i retiradas da literatura (ERISIR et al., 1999) (A) e (McCORMICK et al., 1985) (B).

A figura 17 permite observar a ausência de adaptação pronunciada através da análise da variação do potencial de membrana quando submetido a diferentes valores de injeção de corrente. Da mesma forma que acontece no caso das células estreladas, os interneurônios GABAérgicos, apresentam potencial de repouso estável, que pode ser percebido através da análise do potencial de membrana nos intervalos de tempo que antecedem e sucedem o período referente a injeção de corrente. 
Modelação do processamento visual primário em mamíferos - Capítulo IV.
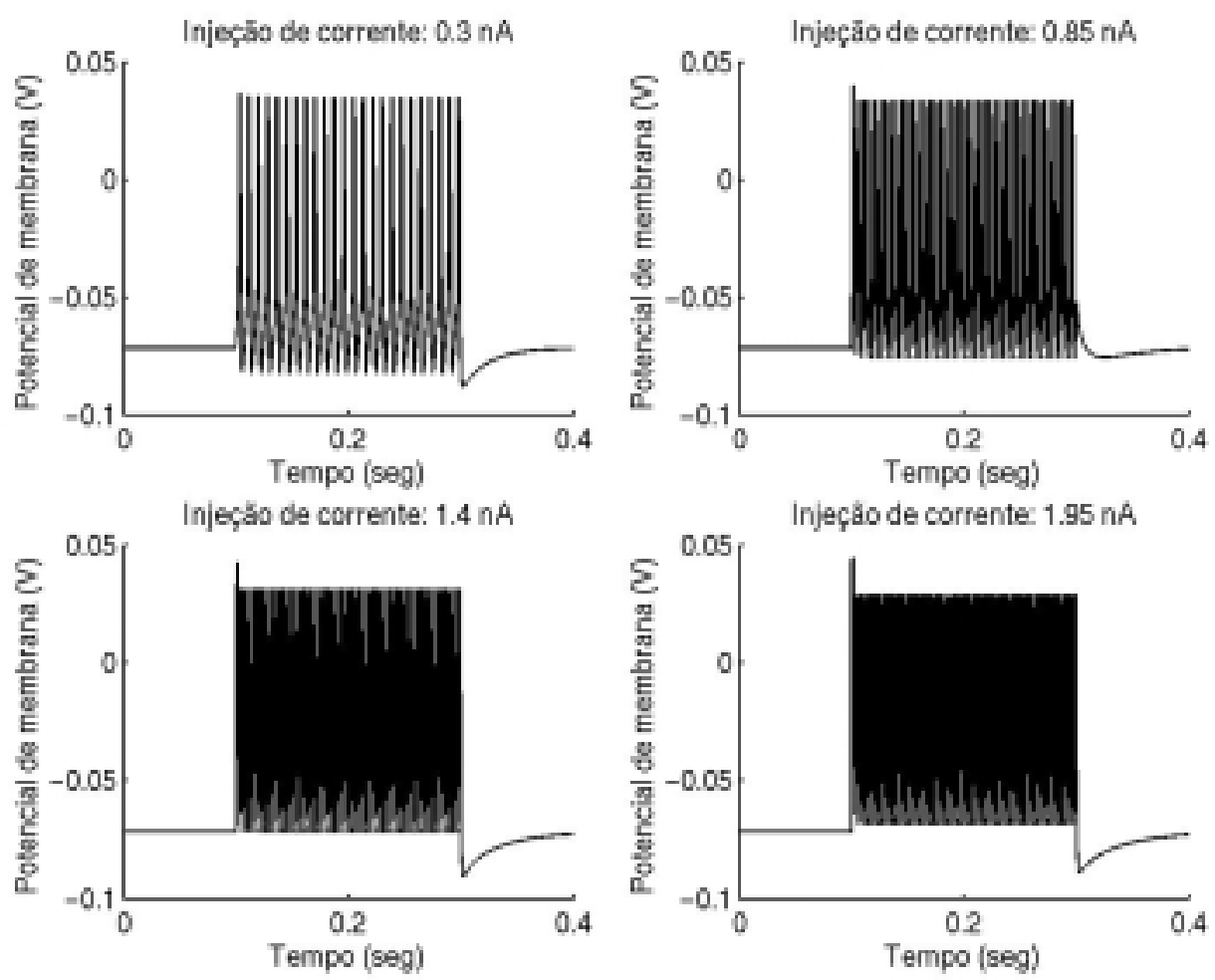

Figura 17. Resposta da célula célula em cesto a diferentes valores de corrente. Os neurônios modelados foram submetidos ao seguinte padrão de estimulação: durante 0,1 seg os neurônios não são submetidos a injeção de corrente, durante os 0,2 seg seguintes, o neurônio é submetido a uma injeção de corrente (os valores estão assinalados no alto de cada gráfico). Em seguida, a injeção de corrente é interrompida. Pode-se perceber que o neurônio possui um potencial $e$ repouso estável e que mediante valores de injeção de corrente sucessivamente aumentados, sua frequência de disparo é também aumentada. Após cessada a estimulação o neurônio retorna ao seu potencial de repouso rapidamente.

Os modelos compartimentais reduzidos apresentaram resultados quantitativamente e qualitativamente semelhantes àqueles descritos na literatura. Diversas características permitem classificá-los de acordo com o esquema proposto por McCORMICK et al. (1985) e CONNORS \& GUTNICK (1990). A utilização de poucos compartimentos e de um elenco reduzido de canais iônicos permitiu que estes modelos de neurônios individuais fossem incluídos na simulação de sistema visual primário.

\section{Estruturas.}

O mecanismo de avaliação mais simples das propriedades dos campos receptivos de neurônios do sistema nervoso é a investigação de sua atividade mediante a apresentação de estímulos com propriedades variáveis. O modelo de sistema visual descrito no capítulo anterior foi simulado e seu comportamento registrado para a avaliação das propriedades dos campos receptivos dos neurônios corticais. As camadas que representam as retinas foram submetidas a estimulação de dois tipos 
Modelação do processamento visual primário em mamíferos - Capítulo IV.

diferentes: (1) grades sinusoidais com orientação, freqüência espacial e contraste variáveis; (2) um padrão de estimulação em que as células da retina geram potenciais de ação de acordo com uma probabilidade determinada e, em consequência disto, uma frequência de disparos pode ser associada às células ganglionares. Estes dois tipos de estimulação foram utilizados em conjunto ou separadamente e a seletividade do modelo à ocularidade e à orientação foi averiguada utilizando os protocolos descritos à seguir. Os dados utilizados para avaliar o comportamento do modelo foram os potenciais de ação e o potencial de membrana de uma fração dos neurônios simulados.

\section{Protocolo I - Ocularidade.}

A investigação da resposta dos neurônios da camada $4 \mathrm{C} \alpha$ e $4 \mathrm{~B}$ com relação a ocularidade foi implementada de acordo com o protocolo descrito a seguir. O sistema foi submetido a um período de estimulação com duração igual a 0,2 seg em que apenas uma das áreas correspondentes às retinas foi ativada. Este nível de atividade foi determinado em função da probabilidade de ocorrência de disparo em um dado intervalo de tempo (veja apêndice II). A atividade de uma fração dos neurônios corticais foi registrada. Em seguida, a área de retina correspondente ao olho que permaneceu inativo na primeira etapa foi ativada por um período $0,2 \mathrm{seg}$ e a atividade dos mesmos neurônios foi registrada.
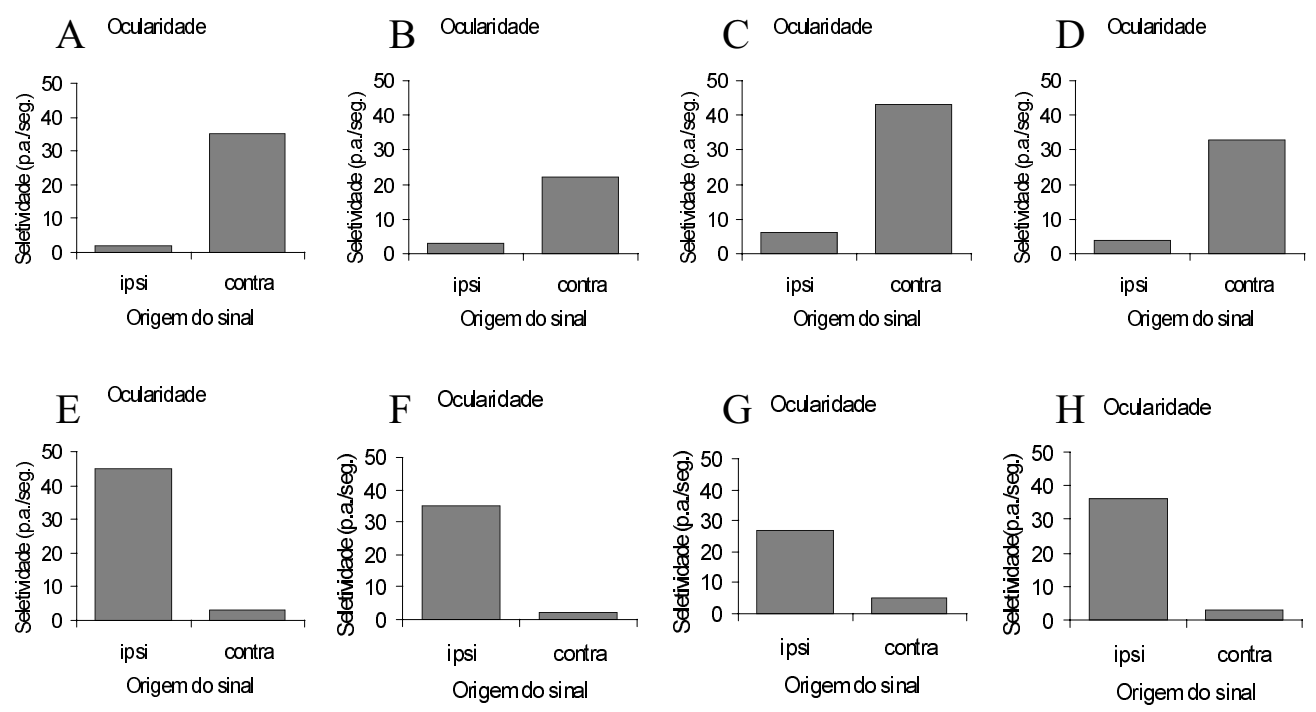

Figura 18. Seletividade a ocularidade em neurônios da camada $4 C \alpha$. Os neurônios foram submetidos ao protocolo descrito no texto e os valores médios de suas seletividades descritas em p.a./seg estão apresentadas nos gráficos de barras acima. As figuras 18 A-D mostram 4 células seletivas a estímulos do olho contralateral as figuras $18 \mathrm{E}-\mathrm{H}$ mostram 4 células seletivas a estímulos do olho ipsilateral.

A seleção dos neurônios envolvidos na avaliação da ocularidade obedeceu ao seguinte critério. Conjuntos de 20 neurônios excitatórios contidos em uma área central de $1 \mathrm{~mm}^{2}$ da camada $4 \mathrm{C} \alpha$ e da 
Modelação do processamento visual primário em mamíferos - Capítulo IV.

camada 4B foram aleatoriamente escolhidos, os tempos de ocorrência de potenciais de ação foram registrados e, naturalmente, a quantidade de potenciais de ação (p.a.). Este protocolo foi repetido 10 vezes e esta quantidade foi então dividida pelo período que durou a estimulação e convertida em uma medida da seletividade destes neurônios a sinais de um ou outro olho. Os valores médios foram computados e estão apresentados a seguir (Fig. 18A-H, Fig. 19 A-D).

Algumas investigações apontam a presença de células seletivas a ocularidade na camada $4 \mathrm{C} \alpha$ mas a maior parte das evidências é de que a maioria das células desta camada além de insensível à orientação, é também monocular, ou seja, responde exclusivamente, a estímulos oriundos de um olho.

O nível de atividade da camada $4 \mathrm{C} \alpha$ é relativamente alto. É possível perceber que a diferença entre as respostas a sinais do olho contralateral e a sinais do olho ipsilateral é grande. As pequenas respostas "inapropriadas" a estímulos do olho ipsilateral (Fig. 18 A-D) e a estímulos do olho contralateral (Fig. 18 E-H), inferiores a 10 p.a./seg na maioria das vezes, podem dever-se a reverberação da atividade excitatória de áreas que recebem aferências talâmicas originárias de uma camada do NGL (sinais de um olho) para células de áreas que recebem aferências talâmicas originárias de outra (sinais de outro olho). Apesar desta pequena atividade, os neurônios da camada 4C $\alpha$ são classificados como monoculares. Os neurônios apresentados na figura 18, mostraram um nível de responsividade em que a atividade média do neurônio em resposta ao olho a que se mostrou mais responsivo foi aproximadamente 8 vezes maior do que aquela apresentada a estímulos do outro olho.
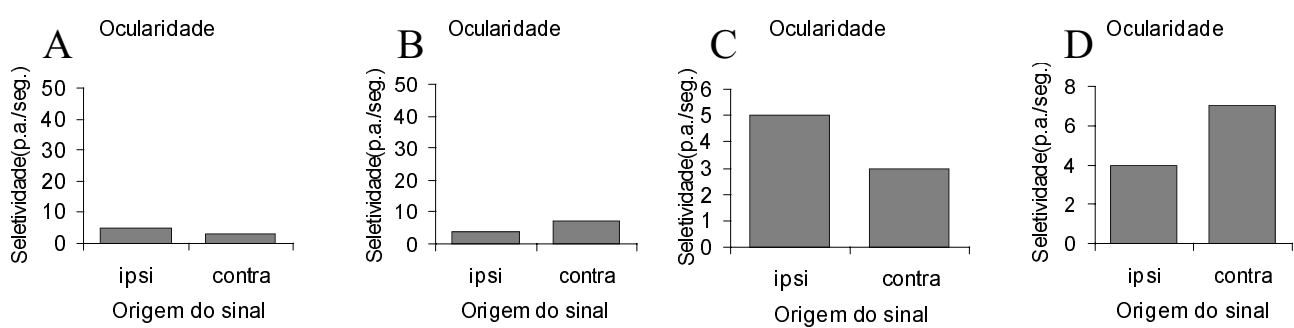

Figura 19. Seletividade a ocularidade em neurônios da camada 4B. Os neurônios foram submetidos ao protocolo descrito no texto e os valores médios de seletividade descritos em p.a./seg estão apresentados nos gráficos de barras acima. As figuras 19 A e C mostram uma célula seletiva a estímulos do olho ipsilateral. As figuras 19 B e D mostram uma célula seletiva a estímulos do olho contralateral. A diferença entre os gráficos $A-B$ e $C-D$ está na escala utilizada. Os gráficos $A-B$ usam a mesma escala utilizada na figura 18. É possível observar as diferenças de nível de atividade entre estas duas camadas.

Os neurônios da camada 4B, por outro lado, tem níveis de atividade muito baixos se comparados aos da camada camada $4 \mathrm{C} \alpha$. De qualquer forma, há também uma diferença entre a atividade destes neurônios quando submetidos ao protocolo de estimulação descrito acima A 
Modelação do processamento visual primário em mamíferos - Capítulo IV.

atividade apresentada pelos neurônios na camada 4B é dominada por um olho mas também sofre influência do outro. A diferença é muito menor do que a diferença apresentada pelos neurônios da camada $4 \mathrm{C} \alpha$. No que diz respeito aos neurônios desta camada esta diferença permite que estes neurônios sejam classificados de acordo com a dominância ocular.

Os neurônios apresentados na figura 19, mostraram um nível de responsividade em que a atividade média do neurônio em resposta ao olho a que se mostrou mais responsivo foi aproximadamente 1,5 vezes maior do que aquela apresentada a estímulos do outro olho.

\section{Protocolo II - Orientação.}

Para avaliar a seletividade á orientação, os neurônios foram submetido ao seguinte protocolo de estimulação. Durante $0,1 \mathrm{seg}$ ambas as áreas correspondentes às retinas foram submetidas a estimulação basal. A probabilidade adotada neste protocolo promove uma frequência de disparo próxima a $10 \mathrm{~Hz}$ nas áreas da retina. Em seguida, por um período de 0,1 seg ambas as retinas foram submetidas a estimulação com uma grade sinusoidal com contraste e orientação variáveis. Em todos os cenários a frequência espacial e a fase espacial foram mantidas constantes (veja apêndice II). A atividade de uma fração dos neurônios corticais foi registrada apenas durante o período em que ocorreu estimulação.

A seleção dos neurônios envolvidos na avaliação da seletividade obedeceu ao seguinte critério. Conjuntos de 20 neurônios excitatórios contidos em uma área central de $1 \mathrm{~mm}^{2}$ da camada 4B foram aleatoriamente escolhidos, os tempos de ocorrência de potenciais de ação foram registrados e, naturalmente, a quantidade de potenciais de ação (p.a.). Cada um destes neurônios foi submetido a estimulação com diferentes valores de contraste $(20 \%$ a $80 \%$ em intervalos $20 \%)$ e orientação $\left(0^{\circ}\right.$ a $180^{\circ} \mathrm{em}$ intervalos de $11,25^{\circ}$ ). Este protocolo foi repetido 10 vezes e esta quantidade foi então dividida pelo período que durou a estimulação e convertida em uma medida da seletividade destes neurônios à orientação. Os valores médios foram computados e estão apresentados na forma de curvas de sintonia. 
Modelação do processamento visual primário em mamíferos - Capítulo IV.
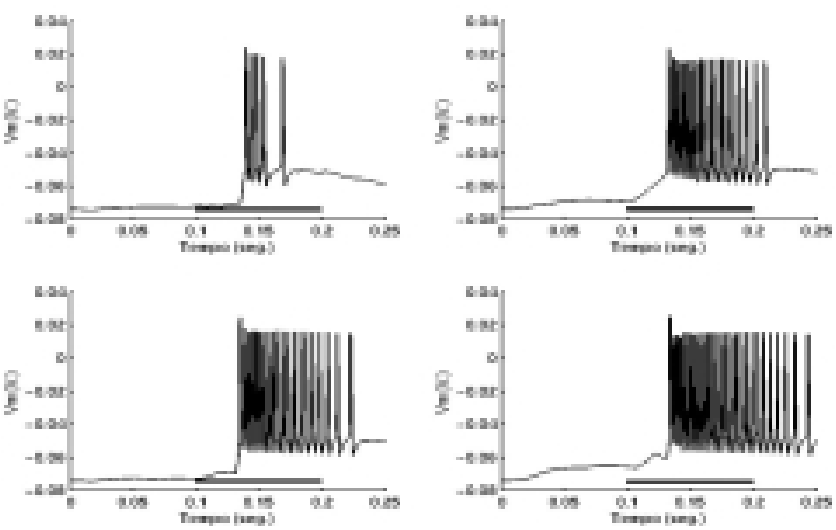

Figura 20. Variação do potencial de membrana de um neurônio seletivo a estímulos com $45^{\circ}$ de orientação quando submetido a estimulação com grade sinusoidal com esta orientação. Partindo do primeiro gráfico à esquerda no canto superior até o último à direita no canto inferior, a estimulação teve seu contraste variado de $20 \%$ até $80 \%$ em intervalos de $20 \%$. A duração da estimulação está marcada em cada gráfico por um traço $(0,1 \mathrm{seg}$ até $0,2 \mathrm{seg})$.
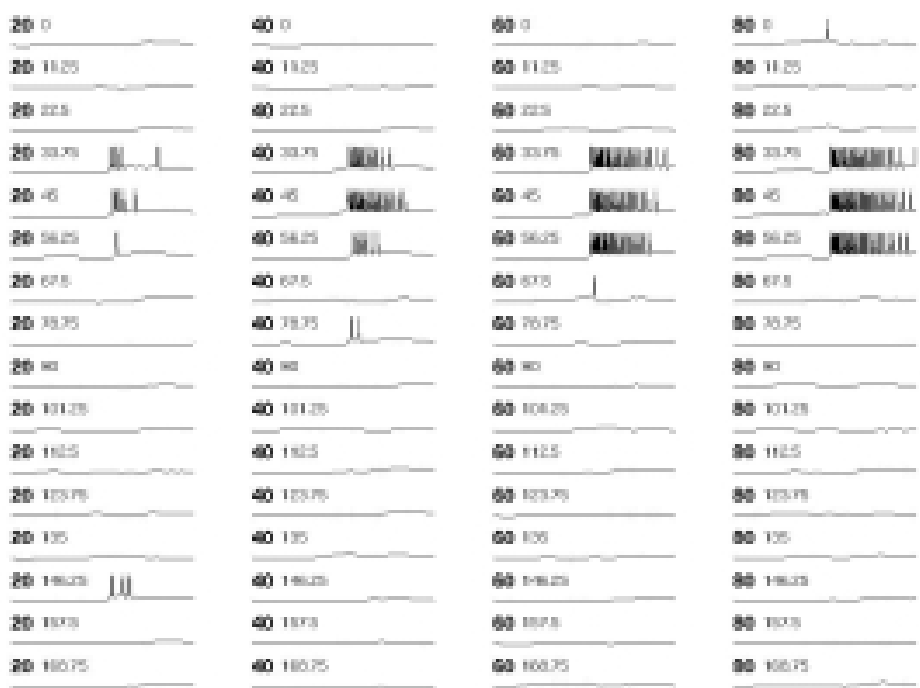

Figura 21. Variação do potencial de membrana de um neurônio seletivo a estímulos com $45^{\circ}$ de orientação quando submetido a estimulação com grade sinusoidal com diversas orientações e contrastes. Para cada gráfico, há dois valores apresentados. $O$ primeiro em negrito, corresponde ao contraste e o segundo, corresponde à orientação. Este protocolo foi repetido 10 vezes e o resultado em p.a./seg foi utilizado na construção das curvas de sintonia.

As curvas de sintonia mostraram-se heterogêneas. Nem todos os neurônios apresentaram seletividade à orientação tão precisa quanto o neurônio cuja variação no potencial de membrana foi utilizada para ilustrar o método empregado para gerar as curvas de sintonia (Fig. 20; Fig. 21; Fig. 22). Entre os neurônios investigados alguns apresentaram um padrão de seletividade bastante amplo (Fig. 23) outros ainda, apresentaram padrões seletivos à orientação mas também sensíveis à 
Modelação do processamento visual primário em mamíferos - Capítulo IV.

contraste, ou seja, à medida em que era aumentado o contraste, a base da curva de seletividade tornava-se mais larga, o neurônio mostrou-se responsivo a uma faixa de orientações mais larga para valores altos de contraste (Fig. 24). Não foi realizado, entretanto, um estudo do padrão de conectividade destes neurônios individuais para averiguar se há alguma relação entre estes comportamentos e as conexões que realiza.

\section{Curva de Sintonia}

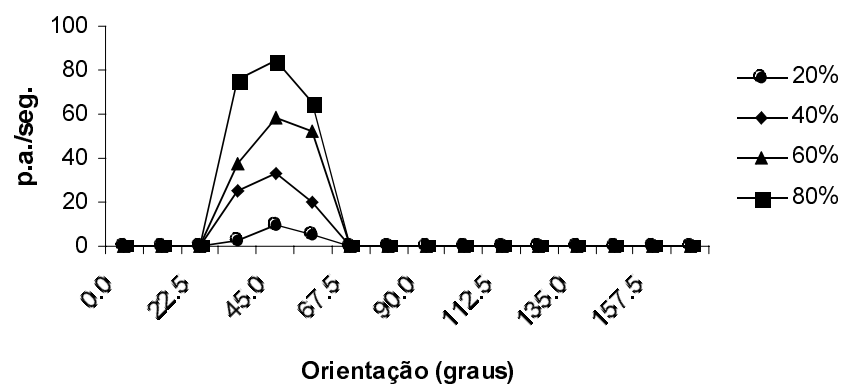

Figura 22. Curva de sintonia do neurônio cuja variação do potencial de membrana foi apresentada nas figuras 20 e 21. Este neurônio é seletivo à estímulos com orientação igual a $45^{\circ}$. A seletividade mostrou-se estável, precisa e invariante à contraste. Os valores de contraste estão assinalados na legenda.

\section{Curva de Sintonia}

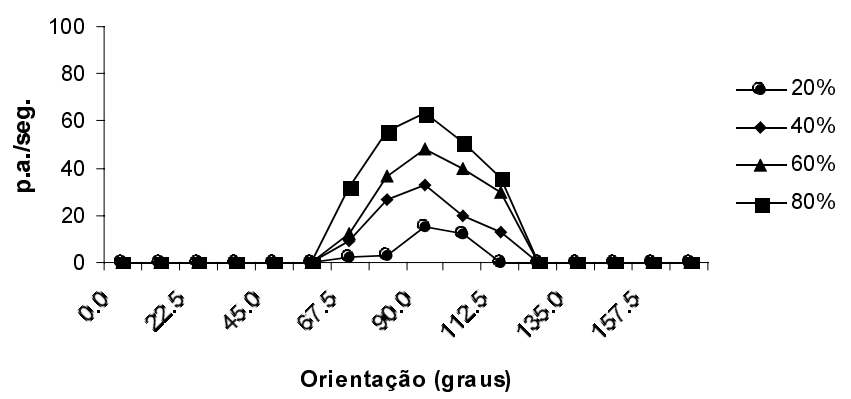

Figura 23. Este neurônio é seletivo à estímulos com orientação igual a $90^{\circ}$. Entretanto, sua seletividade é bem mais ampla do que a seletividade do neurônio apresentada na figura 22. Este neurônio responde a estímulos com orientações até $30^{\circ}$ superiores ou inferiores a $90^{\circ}$. Os valores de contraste estão assinalados na legenda.

A organização desta heterogeneidade não obedeceu a nenhum critério óbvio. Neurônios seletivos a estímulos em diversas orientações mostraram graus de seletividade diferentes mesmo tendo suas conexões estabelecidas utilizando um algoritmo comum, ou seja, resultados colhidos em um mesmo cenário, mostraram diferentes neurônios com diferentes graus de seletividade e 
Modelação do processamento visual primário em mamíferos - Capítulo IV.

sensibilidade à contraste ainda que as regras que estipularam o padrão de conexão tenham sido constantes.

Curva de Sintonia

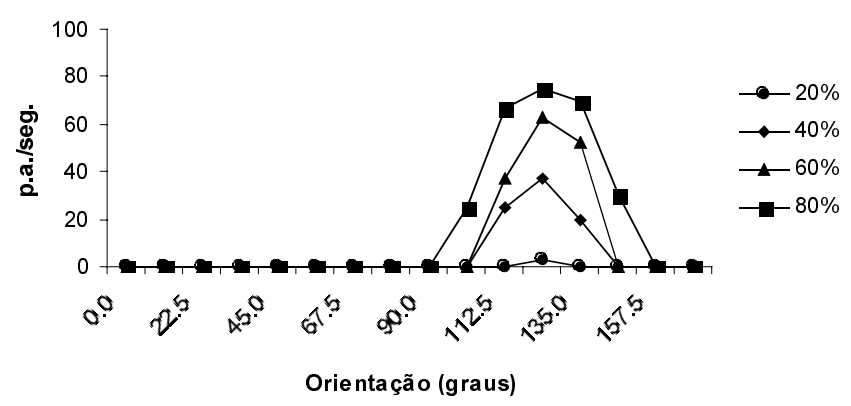

Figura 24. Este neurônio é seletivo à estímulos com orientação igual a $135^{\circ}$. Entretanto, sua seletividade não é invariante à contraste. Para valores de contraste iguais a $80 \%$, este neurônio mostrou-se seletivo à orientações 300 superiores e inferiores a $135^{\circ}$. Os valores de contraste estão assinalados na legenda.

Apesar desta variação no grau de seletividade dos neurônios, o tempo de latência para o surgimento das primeiras respostas seletivas à orientação mostrou-se semelhante àquele apresentado na literatura. Independente do contraste e da orientação da estimulação, as primeiras respostas surgiram aproximadamente $40 \times 10^{-3} \mathrm{seg}$ após o início da estimulação (Fig. 20). A média do tempo de latência dos 20 neurônios avaliados em um cenário foi $37,21 \times 10^{-3} \mathrm{seg}$. Todos os neurônios seletivos à orientação mantiveram um padrão de resposta tônico com flagrante adaptação. A duração deste período em que a resposta dos neurônios foi mantida variou com o valor do contraste e, aparentemente, com o grau de seletividade dos neurônios. Estas observações, entretanto, não foram submetidas a uma avaliação mais profunda. 
Modelação do processamento visual primário em mamíferos - Capítulo V.

\section{Capítulo V}

\section{Discussão e Conclusão.}

Neste capítulo são discutidas as principais aproximações do modelo e suas relações com os resultados. É também discutida a relação dos resultados do modelo com aqueles apresentados em estudos experimentais.

\section{Principais Aproximações.}

Este modelo buscou simular uma área de córtex visual primário do sistema visual de mamíferos. Foram incluídos no modelo diversas características neuroanatômicas e citoarquitetônicas das estruturas que compõem o sistema visual. Os neurônios constituintes foram modelados utilizando-se o instrumental fornecido pelo modelo de geração de potencial de ação de HODGKIN \& HUXLEY (1952) e a equação de cabo (RALL et al., 1992). Entretanto, alguns aspectos não foram incluídos na simulação para torná-la computacionalmente barata, ou para não aumentar sua complexidade ao ponto de tonar a interpretação de seus resultados igualmente complicada. A seguir estes aspectos são indicados e a não inclusão de cada um deles no modelo é discutida.

- Para efeito de barateamento alguns canais iônicos sabidamente presentes em células talâmicas e corticais não foram incluídos nos modelos de neurônio. Estes canais alteram a forma do potencial de ação individual mas influenciam pouco as curvas $f-i$ que foram o principal recurso utilizado na validação dos modelos de neurônios individuais. Por exemplo, os neurônios de relê talâmicos possuem uma quantidade e diversidade de canais impressionante (HUGENARD \& McCORMICK, 1992). Além daqueles incluídos nos modelos de célula talâmica deste estudo, estão presentes canais de cálcio de alto limiar, cálcio de alto limiar (Ca), potássio ativado por Cálcio $\left(K_{A H P}\right)$, entre outros.

- O padrão de estimulação utilizado foi estático. Ou seja, a grade sinusoidal utilizada para averiguar a seletividade à orientação dos neurônios corticais permaneceu estática durante o período de estimulação. Além disso, apenas um filtro espacial foi utilizado para modelar as propriedades espaciais dos campos receptivos da retina, a diferença de gaussianas. O padrão de resposta temporal dos neurônios da retina não foi modelado. Apenas as células ganglionares da classe de neurônios de ativação central (ON-center) foi modelada. Vários estudos experimentais e computacionais tem mostrado que a inativação dos neurônios da classe de inativação central 
Modelação do processamento visual primário em mamíferos - Capítulo V.

(OFF-Center) não são essenciais para a observação de respostas seletivas à orientação (SCHILLER et al., 1986). Estas adaptações foram feitas para tornar o modelo mais barato.

- O NGL contém apenas neurônios de relê. Os interneurônios GABAérgicos também não foram incluídos nesta simulação.

- O padrão de inervação talâmico no córtex foi montado de forma a aproximar-se daquele descrito na literatura. Entretanto, os terminais axonais que apresentam grupos de clusters não foram modelados. Tão pouco foram modelados, os terminais axonais que inervam bandas alternadas seletivas a estímulo oriundo do mesmo olho. Além disso, sabe-se que há uma pequena população de interneurônios GABAérgicos do córtex que recebem conexões do tálamo (PETERS et al. (1994), estimam esta população em 5\% de todos os neurônios que utilizam GABA como neurotransmissor). Entretanto, neste modelo, apenas as células estreladas receberam conexões talâmicas.

- Ausência de conexões horizontais. Além das conexões de curto alcance modeladas neste estudo, existe uma segunda classe de conexões de longo alcance. Este tipo de conexão é realizado entre grupos de células separadas por alguns milímetros no córtex. Estas conexões, ao contrário das conexões de curto alcance, são seletivas e ocorrem entre neurônios com mesmas propriedades funcionais. Por exemplo, neurônios seletivos à sinais oriundos do mesmo olho tendem a conectar-se entre si. Da mesma forma, com um grau relativo de precisão, neurônios seletivos a estímulos com orientações semelhantes, também conectam-se entre si (MALACH et al., 1993; WELIKY et al., 1995; KISVÁRDAY et al., 1997).

- O registro dos dados apresentados no capítulo anterior foi feito apenas em neurônios localizados na área central das camadas corticais. Isto foi feito para evitar um efeito de borda. Ou seja, a densidade de conexões dos neurônios localizados nas bordas das camadas corticais é menor do que a daqueles localizados no centro e isto faz com que seus modos de operação sejam diversos. Além disso, devido ao fato das áreas corticais terem sido modeladas de forma contínua, ou seja as colunas não foram modeladas como matrizes separadas mas sim como áreas corticais adjacentes, alguns campos receptivos foram cortados (veja Fig. 10). Mesmo adotando esta medida não há nenhuma garantia de que os neurônios do centro estejam absolutamente livres do efeito de borda. 
Modelação do processamento visual primário em mamíferos - Capítulo V.

\section{Ocularidade.}

As primeiras investigações sobre as bases anatômicas da seletividade à ocularidade em primatas demonstraram que os neurônios do NGL recebem entradas segregadas dos olhos direito e esquerdo e seus campos receptivos são monoculares (HUBEL \& WIESEL, 1972). A grande maioria das células da camada 4C do córtex de primatas têm campos receptivos também monoculares. Os sinais oriundos das diferentes lâminas do NGL permanecem segregados em áreas que não se sobrepõem (HUBEL \& WIESEL, 1962; HUBEL \& WIESEL, 1968; HUBEL \& WIESEL, 1972). O padrão formado é aproximadamente periódico e regular, especialmente em primatas. Entretanto, existe bastante variação a depender da espécie e mesmo em uma mesma espécie. Observou-se que a largura das colunas ao longo dos limites entre V1 e V2, em primatas, varia entre $670 \times 10^{-6}$ e $395 \mathrm{x}$ $10^{-6} \mathrm{~m}$ (HORTON \& HOCKING, 1996a). O padrão de arborização dos terminais axonais de neurônios talâmicos no cortex de primatas descrito por BLASDEL \& LUND (1983) e por WU et al. (1998) alia-se às evidências anteriores apresentadas por HUBEL \& WIESEL (1972) para compor um quadro em que a base neuroanatômica para as CDO seria a segregação dos terminais axonais oriundos das retinas contralateral e ipsilateral em bandas alternadas no cortex visual primário.

A segregação proposta como base para o desenvolvimento das CDO foi implementada da forma descrita no Capítulo II - O Modelo. Como resultado, as células da camada 4C $\alpha$ apresentaram diferentes níveis médios de resposta aos estímulos apresentados nas retinas ipsi e contralateral. Alguns neurônios que apresentaram alto nível de resposta a estímulos de um olho, apresentaram alguma resposta a estímulos do outro olho, ainda que muito reduzida. Esta resposta pode ser um resquício provocado pela reverberação de atividade excitatória de áreas monoculares que respondem a um olho sobre áreas monoculares que respondem a estimulação do olho contrário. Na camada 4B, por outro lado, os níveis de atividade, mostraram-se muito mais baixos mas a relação entre as respostas a um olho e ao outro olho foi aproximadamente 4 vezes menor. É justamente esta diferença na relação entre as respostas a um olho e ao outro nas duas camadas que permite que se fale em respostas monoculares em 4C $\alpha$ e respostas de dominância ocular em 4B.

\section{Orientação.}

Diversos modelos de conexão intracortical e do padrão de entrada talâmica no córtex têm sido propostos como essenciais desde a primeira descrição deste fenômeno. Estes modelos podem ser agrupados em três classes principais (DAS, 1996). 
Modelação do processamento visual primário em mamíferos - Capítulo V.

O primeiro e mais influente modelo para sensibilidade a orientação de barras foi proposto por Hubel e Wiesel (HUBEL \& WIESEL, 1962; HUBEL \& WIESEL, 1968), os descobridores deste fenômeno. Este modelo propõe que a seletividade à orientação de barras é fruto de um alinhamento apropriado de sinais de entrada. Assim, células talâmicas, cujos campos receptivos pudessem ser agrupados ao longo de uma linha vertical excitariam uma célula cortical. Esta célula, portanto, responderia preferencialmente a bordas verticais (Fig. 25A).

Contudo, à época da proposta de Hubel e Wiesel, não havia nenhuma prova de que apenas este alinhamento geométrico das aferências talâmicas seria suficiente para o aparecimento da seletividade à orientação. Aliado a isto, a entrada do NGL é responsável por apenas $15 \%$ dos contatos sinápticos das células simples da camada 4. O restante das conexões são intracorticais excitatórias ou inibitórias (PETERS et al., 1994).

Além disto, este modelo também não se mostrou capaz de demonstrar a estabilidade da seletividade à orientação quando são apresentados estímulos de diferentes contrastes (FERSTER \& MILER, 2000). Além disso, modelos que propõem apenas o padrão de entrada talâmica como responsável pela seletividade à orientação não têm se mostrado capazes de apresentar a perda de seletividade à orientação quando ocorre a injeção de antagonistas GABAérgicos como, por exemplo, a bicuculina, que reduz a inibição em uma população de neurônios corticais.

Observando esta diferença entre o número de contatos sinápticos excitatórios vindos do NGL e os demais, de natureza intracortical, e a alteração na seletividade de populações de neurônios quando aplicados antagonistas GABAérgicos, outra classe de modelos foi proposta associando a seletividade à orientação a um sistema de inibição intracortical (SOMERS, 1995; DAS, 1996). As células corticais seriam impedidas de disparar na presença de barras em orientações inadequadas pela ação de interneurônios corticais inibitórios. Células corticais inibitórias promovem, segundo esta classe de modelos, a seletividade à orientação da célula cortical alvo, impedindo sua resposta quando a barra não se encontra em uma orientação ótima. Na figura $25 \mathrm{~B}$, por exemplo, um neurônio talâmico que é ativado mediante a apresentação de estímulos em qualquer orientação leva à ativação de interneurônios inibitórios que respondem a orientações diferentes do estímulo (uma barra vertical) levando à ativação dos interneurônios que vão inibir a célula cortical que responde em orientações verticais.

De acordo com este modelo todas as células simples receberiam forte excitação talâmica mediante a apresentação de estímulos em qualquer orientação. A inibição de interneurônios corticais ativados por células simples que respondem a orientações ortogonais seria responsável pela 
Modelação do processamento visual primário em mamíferos - Capítulo V.

seletividade. Boa parte destes modelos prevê que a apresentação de estímulos em orientação ortogonal à orientação preferida por um neurônio cortical levaria a inibição bastante forte.

Contudo, registros intracelulares não demonstraram a forte inibição de neurônios simples quando ocorre apresentação de barras em orientação ortogonal à da célula que estava sendo registrada (FERSTER, 1986). Na verdade, observou-se que os PPSIs mais fortes ocorriam durante a apresentação de estímulos com a orientação preferencial enquanto os PPSIs mais fracos aconteciam durante a apresentação de barras em orientações diferentes da orientação preferencial da célula registrada. Além disso, o bloqueio intracelular da inibição de um neurônio não alterou sua seletividade à orientação (DAS, 1996).

Como resultado destes foi sugerido que a seletividade à orientação poderia ser explicada por um terceira classe de modelos que têm sido conhecidos como modelos de amplificação recorrente (Fig. 25C). Estes modelos propõem que uma circuitaria cortical excitatória de curto alcance e forte

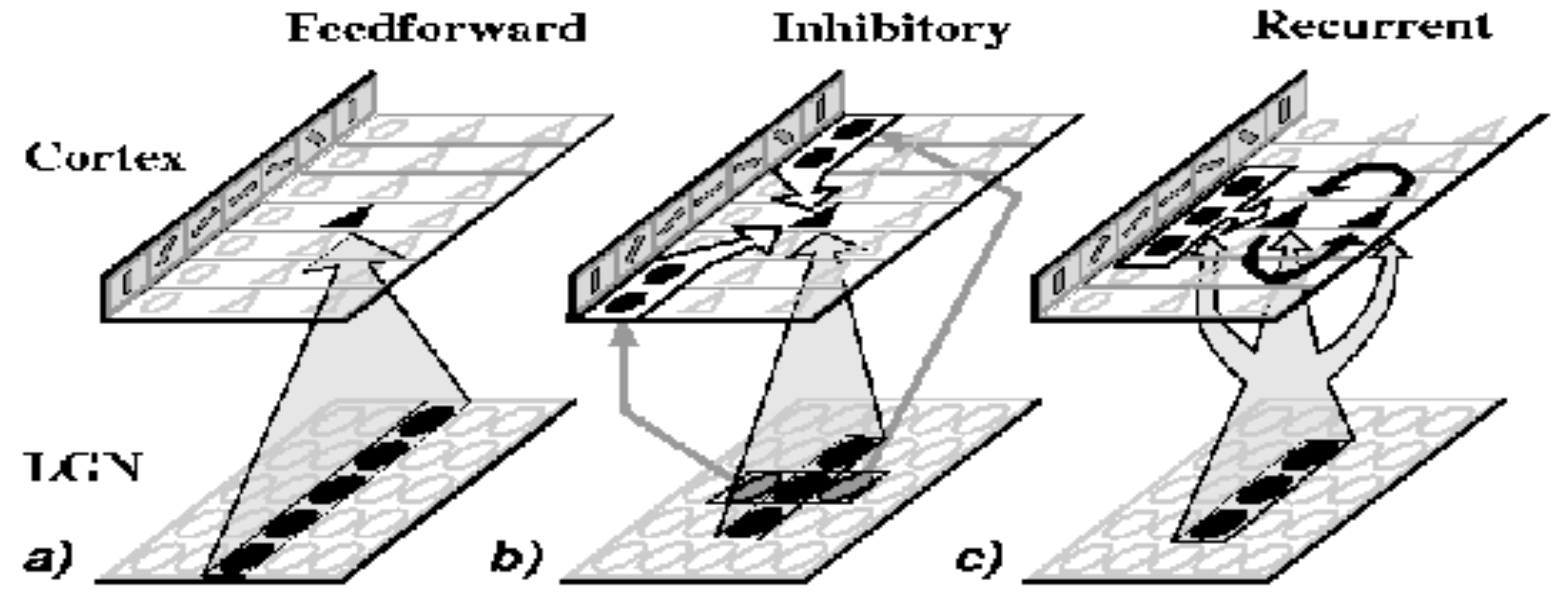

Figura 25. Modelos de seletividade à orientação no córtex visual. a) Modelo de Hubel e Wiesel propõe o alinhamento geométrico das entradas talâmicas como responsável pela seletividade à orientação. Neurônios corticais (triângulos $=$ excitatórios; hexágonos = inibitórios) recebem as entradas talâmicas convergentes alinhadas. b) Inibição de orientações cruzadas. Muitos modelos inibitórios estabelecem uma fraca tendência de alinhamento das entradas do NGL que levaria a uma orientação inicial e utilizam um padrão de circuitaria intracortical inibitória (setas brancas) comprometida com orientações diferentes da célula alvo. Este padrão de circuito suprimiria respostas de neurônios seletivos à diferentes orientações. c) Excitação recorrente. Neste modelo, a excitação cortical entre células preferindo orientações similares combinada com fraca inibição de células de mesma orientação e de orientação diferente atua sobre uma fraca tendencia de alinhamento das entradas do NGL gerando a seletividade à orientação. (Adaptado de (SOMERS et al. 1995)).

inibição entre neurônios de mesma orientação, fraca inibição entre neurônios de orientação diferente e uma pequena tendência á orientação promovida pela entrada talâmica seria responsável pela geração de seletividade à orientação precisa, independente do contraste do estímulo (SOMERS, 1995; DAS, 1996). 
Modelação do processamento visual primário em mamíferos - Capítulo V.

Cada uma das células simples da camada 4 sofre e exerce forte excitação sobre suas células vizinhas como está indicado pelas setas pretas na figura 25C. Estas conexões são de curto alcance e ligam apenas células de mesma orientação ou de orientação semelhante. Isto gera uma cascata de excitação atuando sobre o neurônio alvo. Esta cascata é o que gera a amplificação sobre o sinal talâmico apenas levemente orientado. O sistema de inibição que atua neste modelo não é tão forte quanto o sistema excitatório. Sua ação se restringe somente a impedir que o sistema excitatório fuja ao controle (SOMERS et al. 1995).

Por cerca de trinta anos estes modelos voltados para o estabelecimento de circuitos responsáveis pela seletividade à orientação têm sido propostos. FERSTER et al. (1996) apresentaram uma importante evidência em favor do modelo original de HUBEL \& WIESEL (1962). Foram registrados potenciais sinápticos evocados de células simples do córtex. As orientações destas células foram documentadas e em seguida o córtex foi silenciado por meio de congelamento. Através deste procedimento, as conexões intracorticais excitatórias e inibitórias de curto alcance foram silenciadas. O papel da entrada do NGL pôde ser estudado sem ser perturbado pela ação dos circuitos intracorticais (FERSTER et al., 1996).

Se o modelo proposto por HUBEL \& WIESEL (1962) estiver certo, as células simples do córtex deveriam manter seus padrões de seletividade à orientação basicamente inalterados quando comparados com as medidas originais feitas antes do congelamento. Por outro lado, se os modelos que se apoiam na circuitaria intracortical estiverem certos, e a seletividade à orientarão promovida pela entrada talâmica for apenas uma fraca tendência, as células deveriam ter seu padrão de respostas a estímulos em orientações específicas alterado.

A amplitude dos potenciais evocados foi diminuída porém, a seletividade à orientação permaneceu idêntica. Este resultado, como foi dito anteriormente, privilegia o modelo original apresentado por Hubel e Wiesel.

Contudo, é provável que alguma excitação sináptica tenha permanecido funcional. Conexões sinápticas da camada 6 podem ter permanecido ativas já que estavam longe da placa de congelamento, configurando-se em um pequena fração de excitação. Além disso, é provável que conexões de longo alcance do córtex visual primário e entradas de outras áreas do córtex visual como V2, V3 e V4 tenham exercido também alguma excitação (FERSTER et al., 1996).

Por fim, mais de trinta anos depois de Hubel e Wiesel descreverem a seletividade à orientação nas células simples da camada 4 de mamíferos e proporem um modelo responsável pelo fenômeno em que os campos receptivos circulares e simétricos dos neurônios talâmicos que excitam uma determinada célula cortical estão geometricamente alinhados, novos experimentos demonstraram 
Modelação do processamento visual primário em mamíferos - Capítulo V.

que, realmente, o padrão de entrada das células talâmicas é suficiente para a formação dos campos receptivos das células simples do córtex visual primário.

Os resultados apresentados por FERSTER et al. (1996) não encerram o debate sobre a seletividade à orientação. Entretanto, estabelecem algumas bases importantes que devem direcionar a pesquisa nesta área daqui para frente. Sabe-se hoje que o padrão de entrada talâmico é suficiente para promover a seletividade à orientação; contudo, é preciso estabelecer até que ponto, elementos dos demais modelos propostos estão atuando de forma a otimizar a entrada talâmica. É possível que a circuitaria cortical seja responsável pela correção de não linearidades das células simples do córtex visual, o que explicaria a estabilidade das respostas destas células mediante as alterações no contraste e intensidade do estímulo (DAS, 1996).

A maior parte dos dados apresentados até aqui foi colhida em gatos. O sistema visual de primatas, entretanto, tem algumas peculiaridades. Entre elas está o fato de que, a seletividade à orientação não se apresenta de maniera pronunciada na camada $4 \mathrm{C} \alpha$. Na verdade, a maior parte das células desta camada são monoculares e não seletivas à orientação (CALLAWAY, 1998). Em vista disto, modelos que propõem mecanismos intracorticais como responsáveis pelo surgimento de seletividade à orientação ganham destaque. Entretanto, o padrão de conexão intracortical de curto alcance não parece guardar relação espacial com os sistemas colunares. Tanto as árvores dendríticas quanto os terminais axonais dos neurônios do córtex visual primário estendem-se por regiões cujos limites situam-se até $400 \times 10^{-3} \mathrm{~m}$ de distância do corpo celular e atravessam de forma indiscriminada os limites de colunas de seletividade a orientação adjacentes (MALACH et al., 1993; WELIKY et al., 1995; KISVÁRDAY et al., 1997).

A seletividade do modelo desenvolvido neste estudo está diretamente relacionada com o padrão de conexão entre a camada $4 \mathrm{C} \alpha$ e a camada 4B. É este padrão de conexão com campos receptivos orientados que confere aos neurônios da camada 4B a primeira tendência à seletividade. Este padrão de conexão pode estar organizado em organismos de duas maneiras. A primeira é através da convergência das entradas da camada $4 \mathrm{C} \alpha$ sobre os conjuntos de neurônios da camada $4 \mathrm{~B}$ que compõem as CSO. A segunda é através do alinhamento das árvores dendríticas ao invés dos terminais axonais. Qualquer uma destas formas implica apenas no deslocamento do padrão de conexão que está organizado entre o tálamo e o córtex em gatos para um estágio intracortical em primatas. Os padrões de conexão intralaminar nas camadas $4 \mathrm{C} \alpha$ e $4 \mathrm{~B}$, promovem a manutenção da resposta pelo período que corresponde à apresentação do estímulo e o impedimento da ocorrência de respostas não apropriadas em neurônios localizados em colunas seletivas a outras orientações. 
Modelação do processamento visual primário em mamíferos - Capítulo V.

A relação entre os padrões de circuitaria excitatória e inibitória nas duas camadas corticais é apenas uma entre várias outras possíveis. Diversos indícios permitem suspeitar que ela não seja a mais apropriada para a geração das propriedades dos campos receptivos em V1. Entre eles está a heterogeneidade dos níveis de seletividade apresentados pelos neurônios da camada 4B; a ocorrência de disparos de neurônios corticais monoculares que recebem inervação do lho ipsilateral quando submetidos a estimulação do olho contralateral na camada $4 \mathrm{C} \alpha$ e os baixos níveis de atividade apresentados pelos neurônios da camada 4B. A relação entre estes padrões deve ser estudada em etapas futuras.

De qualquer forma, o estabelecimento do padrão de circuitaria inespecífico utilizado neste estudo mostrou-se capaz, nesta primeira etapa, de apresentar resultados qualitativamente semelhantes àqueles apresentados na literatura.

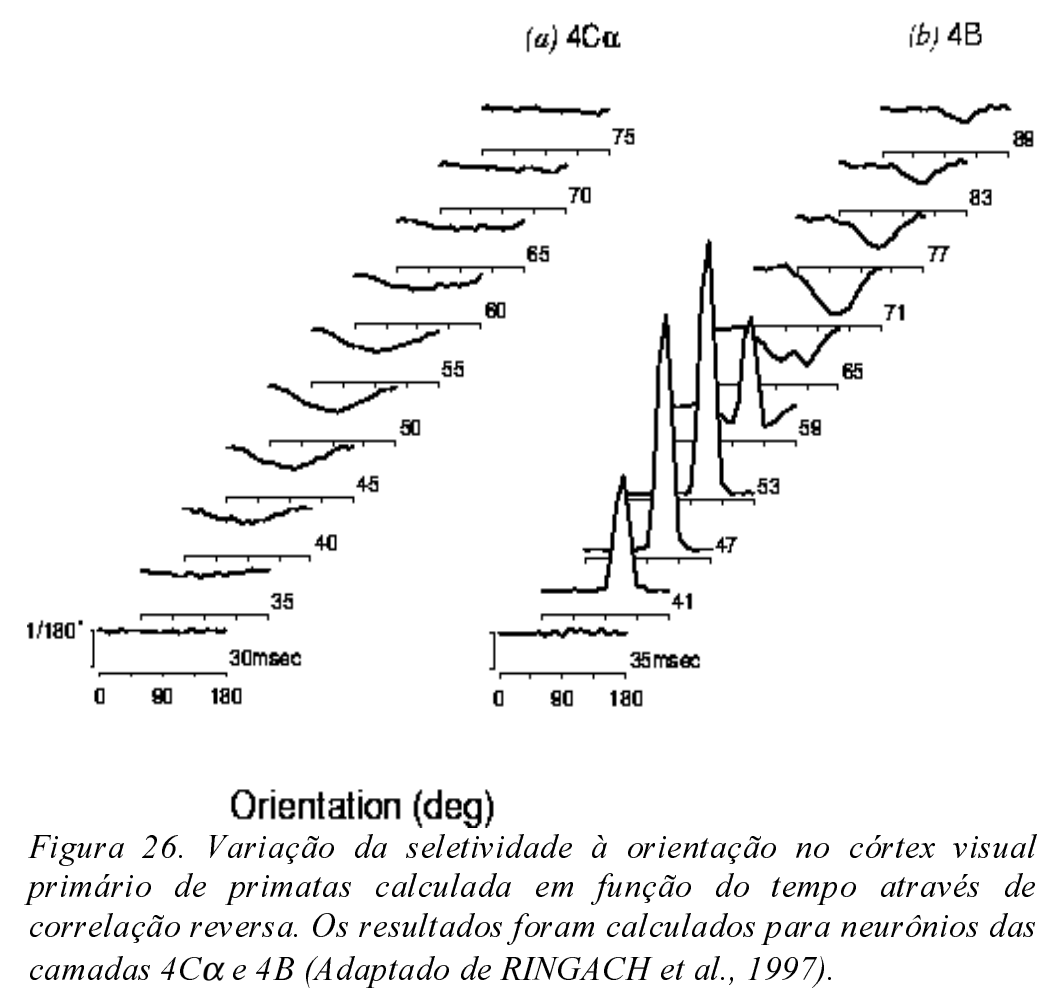

A organização temporal da eletividade á orientação foi investigada por alguns autores recentemente (RINGACH et al, 1997). Na camada 4C $\alpha$ que recebe a entrada do canal magnocelular, a seletividade à orientação mostrou-se baixa mas na camada 4B, a seletividade mostrou-se alta. Os neurônios foram submetidos a estimulação com grades sinusoidais apresentadas por períodos breves e a atividade dos neurônios foi registrada. As correlações entre a variação temporal dos padrões de estimulação e a atividade dos neurônios corticais foi medida e está apresentada na figura 26. Pode- 
Modelação do processamento visual primário em mamíferos - Capítulo V.

se perceber que há uma dramática mudança no padrão das curvas ao longo do tempo. As respostas mais fortes foram observadas entre $41 \times 10^{-3} \mathrm{seg}$ e $65 \times 10^{-3} \mathrm{seg}$. Em seguida a curva se inverte. Os autores não informam se foram testados diferentes valores de contraste.

Os resultados gerados pelo modelo apresentado nesta investigação apresentam tempo de latência para o surgimento das respostas seletivas semelhante àquele reportado na literatura $\left(37,21 \times 10^{-3}\right.$ seg). Esta latência mantém-se constante independente do contraste. Entretanto, para valores altos de contraste, a resposta mantém-se tônica e estende-se por períodos maiores do que os perírodos de estimulação ainda que haja alguma adaptação (Fig. 20).

\section{Comentários Finais.}

A utilização de modelos biologicamente plausíveis no estudo das funções corticais vem somarse a ramos mais tradicionais das neurociências para compor um quadro que permite o intercâmbio entre pesquisadores teóricos e experimentais. Estes modelos tem se mostrado capazes de reproduzir caraterísticas complexas dos sistemas modelados e mesmo de prever aspectos relacionados a este sistemas que de outra forma, lançando mão apenas dos recursos experimentais, seriam de difícil investigação.

O modelo apresentado neste trabalho teve suas conexões estabelecidas topograficamente e mostrou-se capaz de reproduzir as propriedades dos campos receptivos de neurônios corticais. Mais do que isto, este modelo é um dos poucos a apresentar neurônios com campos receptivos binoculares e seletivos à orientação. Respostas de seletividade à ocularidade e à orientação foram observadas e estão em acordo com os registros experimentas. Os padrões de resposta a estímulos orientados mostraram-se heterogêneos e, por vezes, sensíveis a alterações no contraste. Entretanto, o tempo de latência para surgimento de respostas seletivas à orientação está em excelente acordo com os dados reportados na literatura.

Estes resultados corroboram o nível de plausibilidade biológica deste modelo e permitem classifcá-lo como um instrumento útil na investigação de fenômenos do córtex visual primário de mamíferos. É preciso ainda estabelecer qual os elementos essenciais para a geração dos comportamentos observados aqui. Em uma etapa futura o modelo deve, além de superar algumas das simplificações apresentadas neste capítulo, encorporar outros dados anatômicos e ser empregado no estudo de outros temas relacionados ao processamento visual primário. Entre eles, oscilações em sistemas cortico-talâmicos e plasticidade cortical. 


\section{Apêndice $\mathrm{I}$.}

Equação de Cabo; Equação de Hodgkin e Huxley; Canais iônicos e sinápticos.

Sabe-se bastante sobre os mecanismos biofísicos responsáveis pela geração da atividade neural. Estes mecanismos constituem a base utilizada para a construção de modelos. Neste apêndice são discutidos estes mecanismos e os modelos matemáticos utilizados para descrevê-los.

A)

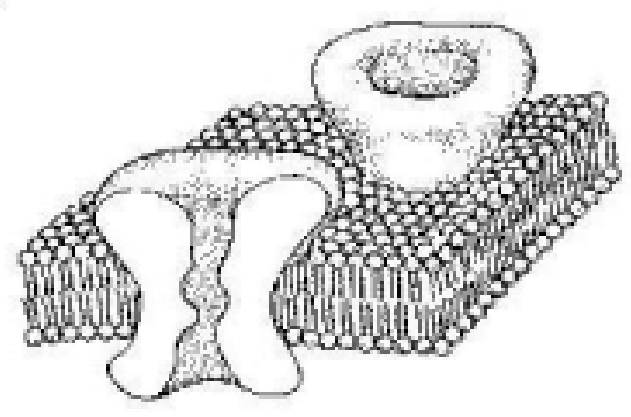

B)

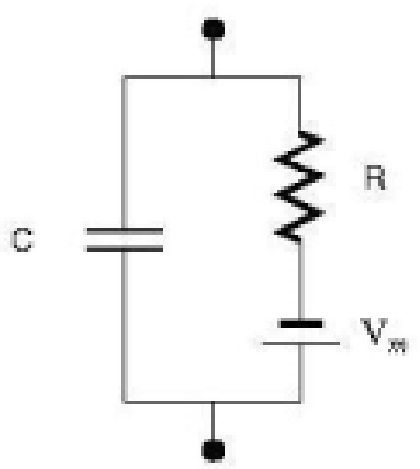

Figura 27. A) Representação de uma área da membrana de neurônios com dois canais iônicos presentes. Pode-se observar as duas camadas de moléculas fosfolipídicas com suas extremidades polares voltadas para as faces interna e externa da membrana. B) Circuito elétrico associado. Este circuito consiste em um capacitor $C$ e uma resistência $R$ em série com uma bateria $V_{m}$ (adaptado de (KOCH, 1998)).

A membrana celular é uma camada bilipídica impermeável a moléculas eletricamente carregadas presentes no interior e no exterior do neurônio (Fig. 27). A maior parte do tempo, há um excesso de cargas negativas dentro do neurônio. Cargas móveis como íons, repelem-se mutuamente mas aglutinam-se na face interna da membrana atraídas por uma força eletrostática gerada pela presença de uma densidade igual de cargas positivas aglutinadas na face externa da membrana. Esta propriedade isoladora faz com que a membrana aja como um capacitor separando as cargas presentes na face interior e exterior da membrana.

Esta diferença na concentração de íons de diferentes cargas dentro e fora da membrana promove a geração de uma diferença de potencial entre o meio interno e o meio externo do neurônio. Por convenção, o potencial do meio extracelular é definido como zero. Quando um neurônio está inativo, o potencial dentro do neurônio é negativo. Este é um ponto de equilíbrio em que o fluxo de cargas (íons carregados) entrando e saindo da membrana é igual e recebe o nome de potencial de repouso.

A capacitância $C$ é uma medida de quanta carga $Q$ deve ser distribuída nas superfícies interna e externa da membrana para que uma certa diferença de potencial $V_{m}$, seja mantida.

$Q=C V_{m}$ 
Para especificar parâmetros que sejam independentes das dimensões, unidades específicas são usadas. A capacitância de membrana é proporcional à área e, portanto, é expressa em termos de capacitância específica de membrana $C_{M}$ cuja unidade é $F / \mathrm{m}^{2}$. A capacitância de membrana $C_{m}$ de um compartimento qualquer pode ser obtida multiplicando-se o valor de $C_{M}$ pela área do compartimento modelado. A espessura da membrana e a constante dielétrica da membrana determinam o valor de $\mathrm{C}_{\mathrm{M}}$.

Quando ocorre variação no potencial de membrana, há trânsito de cargas. Este trânsito de cargas não se dá através da membrana, mas sim através das proteínas que a atravessam e permitem, de forma seletiva, a passagem de alguns íons e não de outros. Para um compartimento cilíndrico, a resistência de membrana é inversamente proporcional à área do cilíndro, portanto a resistência específica de membarana $\mathrm{R}_{\mathrm{M}}$ é definida em $\Omega \mathrm{m}^{2}$. Os compartimentos cilíndricos são conectados entre si através de suas resistências axiais que correspondem a resistência intracelular do citoplasma. A resistência axial de um compartimento cilíndrico é proporcional ao seu comprimento e inversamente proporcional à sua área transversal. Portanto, a resistência axial específica de membrana $R_{A}$ é definida em $\Omega m$. A resistência de membrana $\left(R_{m}\right)$; e a resistência axial $\left(R_{a}\right)$.

O GENESIS permite que os neurônios sejam implementados levando-se em consideração suas propriedades fisiológicas e morfológicas. Isto significa que é possível considerar um modelo canônico de árvore dendrítica bem como a existência e densidade de canais iônicos e sinápticos responsáveis pelo repertório de capacidades computacionais do neurônio. A ferramenta matemática utilizada para modelar estas propriedades é a teoria de cabo. O modelo de compartimento cilíndrico equivalente (modelo do cabo) desenvolvido por Rall (RALL et al., 1992) foi usado para tratar a estrutura eletrotônica dos dendritos e corpos celulares. As árvores dendríticas dos modelos de neurônios foram modeladas por um pequeno conjunto de compartimentos contendo apenas propriedades passivas e canais sinápticos.

Para um compartimento de comprimento $l$ e diâmetro $d$, temos:

$$
\begin{aligned}
& C_{m}=\pi l d C_{M} \\
& R_{m}=\frac{R_{M}}{\pi l d} \\
& R_{a}=\frac{4 l R_{A}}{\pi d^{2}}
\end{aligned}
$$

Tanto o núcleo citoplásmico como as membranas neuronais (através de canais iônicos) são capazes de conduzir correntes elétricas. Contudo, a resistência através da membrana é muito maior do que a resistência através do núcleo citoplásmico. Além disso, a membrana também é capaz de armazenar cargas iônicas. Estas propriedades de resistor e capacitor da membrana implicam em uma constante de tempo para o carregamento e descarregamento do capacitor. A resistência da 
membrana e do citoplasma geram uma resistência de entrada em qualquer ponto da árvore dendrítica. Usando esse modelo, o dendrito pode ser tratado como um compartimento cilíndrico caracterizado pelas constantes de espaço $(\lambda)$ e tempo $\left(\tau_{m}\right)$, pelo comprimento eletrotônico $(\mathrm{L})$ e pela resistência de entrada $\left(\mathrm{R}_{\text {in }}\right)$.

$$
\begin{aligned}
& \tau_{m}=R_{m} C_{m} \\
& \lambda=\sqrt{\frac{d}{4} \frac{R_{M}}{R_{A}}} \\
& L=l / \lambda \\
& R_{i n}=\frac{2}{\pi} d^{-3 / 2} \sqrt{R_{m} R_{a}}
\end{aligned}
$$

onde: $R_{m}=$ resistência especifica da membrana; $C_{m}=$ capacitância especifica da membrana; $R_{a}=$ resistência axial da membrana; $l=$ comprimento do compartimento; $d=$ diâmetro do compartimento.

No sistema nervoso o potencial de ação é gerado no cone axonal e segue pelo axônio da célula pré-sináptica até os terminais axonais onde por meio de sinapse, promove alterações no potencial de membrana da célula pós-sináptica. A equação de cabo foi aplicada às neurociências para desenvolver uma descrição matemática da variação desta alteração do potencial de membrana no espaço $(x)$ e no tempo $(t)$. Este instrumento fornece um meio para investigar de que forma a morfologia de uma árvore dendrítica influencia as características de um neurônio como integrador de informações.

A equação de cabo que descreve este fluxo para um compartimento qualquer é dada por:

$$
\lambda^{2} \frac{\partial^{2} V}{\partial x^{2}}-\tau_{m} \frac{\partial V}{\partial t}-V=0
$$

\section{O modelo de Hodgkin-Huxley.}

$\mathrm{O}$ modelo de $\mathrm{H}-\mathrm{H}$ é baseado na idéia de que as propriedades de um segmento de membrana podem ser modeladas por um circuito equivalente. Hodgkin e Huxley desenvolveram seu modelo utilizando medidas tomadas no axônio gigante da lula. Este axônio tem um diâmetro relativamente grande o que facilitou o registro dos dados. Para evitar a complexidade que seria introduzida no modelo, pela heterogeneidade na distribuição de cargas nas faces interna e externa da membrana ao longo do axônio, foi introduzido em sua extensão um fio com alta condutividade para promover o balanceamento destas cargas ao longo do axônio. Aliado a isto, o uso de diversos agentes farmacológicos permitiu a eles bloquear algumas correntes específicas e assim, avaliar os moldes constituintes da corrente total que percorre o circuito. A corrente total na membrana pode ser descrita como sendo a soma das correntes iônicas mais a corrente capacitiva. 


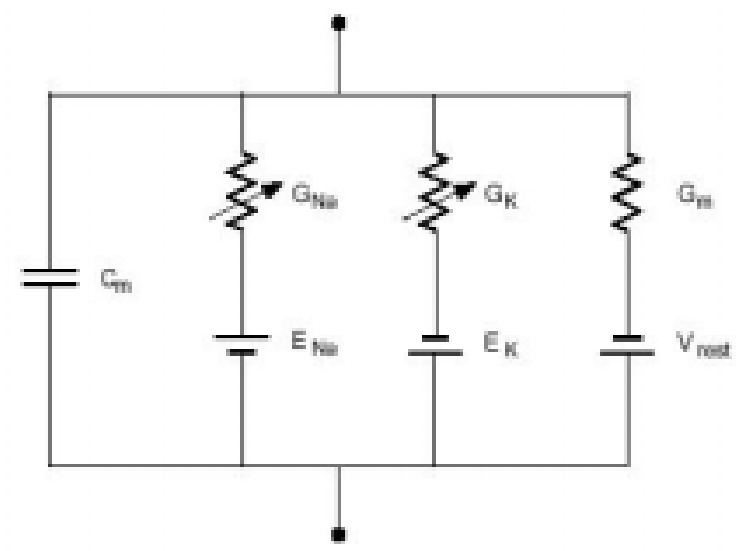

Figura 28. Circuito elétrico equivalente a um segmento de membrana da lula. Hdgkin e Huxley utilizaram este circuito composto por um capacitor $C_{m}$, uma condutância de vazamento $G_{m}=1 / R_{m}$ e duas condutâncias dependentes da voltagem e do tempo para o sódio e o potássio em seu modelo para geração do potencial de ação (adaptado de (KOCH, 1998)).

$$
I_{m}(t)=I_{\text {iônica }}(t)+C_{m} \frac{d V(t)}{d t}
$$

Medindo a intensidade destas correntes, estes autores postularam o seguinte modelo fenomenológico:

1. A geração do potencial de ação envolve duas correntes iônicas dependentes da voltagem, $\mathrm{I}_{\mathrm{Na}}$ e $\mathrm{I}_{\mathrm{K}}$.

Elas são independentes uma da outra. Há ainda uma terceira corrente de vazamento que não depende do potencial de membrana $\mathrm{I}_{\mathrm{M}}$. E representa uma contribuição menor provocada pela presença de alguns íons como o cloro, por exemplo.

$I_{\text {iônica }}=I_{N A}+I_{K}+I_{M}$.

2. As correntes iônicas estão diretamente relacionadas ao potencial de membrana de acordo com a lei de Ohm e podem ser expressas na forma de condutâncias dependentes da voltagem:

$I_{i}(t)=G_{i}(V(t),(t))\left(V(t)-E_{i}\right)$,

Cada condutância $G_{i}$ está em série com uma bateria que representa este potencial reverso, $E_{i}$. O circuito apresentado na figura 28, também conhecido como "circuito equivalente", descreve adequadamente um segmento de membrana. O potencial reverso $E_{i}$ é dado para cada íon pela equação de Nernst,

$$
E_{i}=\frac{k T}{z_{i} e} \ln \left(\frac{c_{i, e}}{c_{i, i}}\right) \text {, }
$$

onde $c_{i, e}$ e $c_{i, i}$ são as concentrações iônicas no espaço extracelular e intracelular, respectivamente, $z_{i}$ é a valênciado íon, $e$ é a carga elementar, $k$ é a constante de Boltzmann e $T$ é a temperatura absoluta. 
3. Cada uma das condutâncias é expressa como uma condutância máxima $g_{i}$, multiplicada por um valor numérico que corresponde à fração de canais ativos. Estes valores são funções que aproximam o comportamento de partículas fictícias que descrevem as cinéticas de abertura e fechamento dos canais.

$G_{i}(V(t),(t))=g_{i} m_{i}^{p_{i}} h_{i}^{q_{i}}$,

onde $m_{i}$ e $h_{i}$ representam estas partículas de ativação e inativação, respectivamente, e são funções dependentes da voltagem e do tempo. Seguindo a notação inaugurada por HODGKIN \& HUXLEY (1952), os canais que não possuem partículas de inativação, têm sua partícula de ativação descrita pelo termo $n_{i}$. Enquanto, $p_{i}$ e $q_{i}$ são constantes numéricas frequentemente inteiras. Estas constantes são ajustadas para conferir ao modelo uma melhor aproximação com os dados experimentais.

Uma interpretação super-simplificada mas útil é que a corrente iônica flui por um conjunto de canais do tipo $i$ que tem $p_{i}$ partículas $\mathrm{m}$ e $q_{i}$ partículas $\mathrm{h}$. As partículas se abrem e fecham de acordo com certas probabilidades. Um canal individual permite a passagem de corrente somente se todos as suas partículas estiverem em estado aberto.

Transições entre o estado aberto e o estado fechado são governadas por taxas de transição $\alpha_{m h} \mathrm{e}$ $\beta_{m h}$

$$
\begin{aligned}
& \frac{d m}{d t}=\alpha_{m}(V)(1-m)-\beta_{m}(V) m, \\
& \frac{d h}{d t}=\alpha_{h}(V)(1-h)-\beta_{h}(V) h .
\end{aligned}
$$

As taxas, por sua vez, são função do potencial de membrana $V$. Ao invés de expressões que descrevem a taxas de transição, pode-se especificar os valores assintóticos das partículas $m_{\infty}$ e $h_{\infty}$ e das constantes temporais $\tau_{m h h}$. A relação com as taxas de transição é dada por:

$$
\begin{aligned}
& m_{\infty}(V)=\frac{\alpha_{m}(V)}{\alpha_{m}(v)+\beta_{m}(V)} \\
& h_{\infty}(V)=\frac{\alpha_{h}(V)}{\alpha_{h}(v)+\beta_{h}(V)} \\
& \tau_{m / h}(V)=\frac{1}{\alpha_{m / h}(V)+\beta_{m / h}(V)}
\end{aligned}
$$

Os valores assintóticos das partículas $m_{\infty}$ e $h_{\infty}$, para alguns canais, são funções sigmóides da forma:

$$
m_{\infty} / h_{\infty}=\frac{1}{1+e^{\left(V(t)-V_{1 / 2}\right) / K}},
$$


onde $V_{l / 2}$ corresponde a metade da ativação da voltagem, $K$ confere a inclinação da sigmóide. Os canais que foram modelados utilizando a função sigmóide da forma exposta acima tem seus parâmetros listados na tabela 8 .

Os canais de sódio transiente (Na) e potássio retificador $(\mathrm{K})$ são responsáveis, respectivamente, pela geração dos potenciais de ação e repolarização do potencial de membrana trazendo-o de volta ao potencial de repouso. A corrente de potássio retificador tem uma ativação mais lenta do que a do sódio tansiente e é inativada ainda mais lentamente. Além de ser responsável pela repolarização do potencial de ação, é responsável também pela hiperpolarização que se segue ao potencial de ação. $\mathrm{O}$ canal de cálcio de alto limiar $(\mathrm{Ca})$ inserido nas células corticais é sensível a alterações na voltagem e sua ativação se dá em potenciais de membrana acima de $-0,040 \mathrm{~V}$. Graças a isso, é também conhecido como "canal de cálcio ativado por alta voltagem". Coletivamente, estes canais também contribuem para a geração de potenciais de ação em neurônios de mamíferos, mas mais importante do que isto é o fato de que eles permitem a entrada de íons $\mathrm{Ca}^{++}$na célula. Isto leva a ativação de canais de potássio ativados por cálcio $\left(K_{A H P}\right)$. O canal de potássio ativado por cálcio é sensível ao aumento na concentração de cálcio mas não é sensível a alteração na voltagem. A principal função deste canal iônico é gerar a adaptação na frequência de disparos. O canal de potássio transiente $\left(K_{A}\right)$ é sensível à voltagem e é ativado por despolarização acima de - 0,06 V. e, em seguida, rapidamente inativado. Este canal gera um aumento nos IPA, diminuindo, de maneira geral, a frequência de disparos do neurônio.

Tab. 8. Parâmetros para os canais iônicos modelados como condutâncias ativas. Onde há dois valores, o primeiro se refere a partícula $m$ (ativação) e o segundo se refere à partícula h (inativação). Os valores de $\tau$ foram mantidos constantes nestes canais. Estes parâmetro foram baseados em dados retirados da literatura (BERNANDER, et al., 1991).

\begin{tabular}{l|c|c|c|c|c}
\hline & $\boldsymbol{G}_{\boldsymbol{N} \boldsymbol{a}}$ & $\boldsymbol{G}_{\boldsymbol{K}}$ & $\boldsymbol{G}_{\boldsymbol{K} \boldsymbol{A}}$ & $\boldsymbol{G}_{\boldsymbol{K} \boldsymbol{A H \boldsymbol { P }}}$ & $\boldsymbol{G}_{\boldsymbol{C a}}$ \\
\hline$V_{l / 2} \times 10^{-3} V$. & $-40 / 45$ & -40 & $-65 /-60$ & - & -25 \\
\hline$p_{i} / q_{i}$ & $2 / 1$ & 2 & $2 / 1$ & 2 & 2 \\
\hline$K \times 10^{-3}$ & $-3 / 3$ & -3 & $-2 / 4$ & - & -4 \\
\hline$\tau \times 10^{-3} \mathrm{seg}$ & $0,05 / 0,5$ & 2 & $20 / 100$ & 2 & 2 \\
\hline$E_{i} \times 10^{-3} \mathrm{~V}$ & 50 & -95 & -95 & -95 & 115 \\
\hline
\end{tabular}

O cálcio entra na célula quando canais de cálcio são ativados e é removido por diversos mecanismos diferentes (entre eles, bombas de cálcio). Esta variação é dada por:

$$
d \frac{\left[\mathrm{Ca}^{+2}\right]}{d t}=\alpha I_{C a}-\frac{\left[\mathrm{Ca}^{+2}\right]}{\tau_{\mathrm{Ca}}}
$$

onde $\alpha$ é $10^{10} \mathrm{M} / \mathrm{C}$ e $\tau_{\mathrm{Ca}}$ é $50 \times 10^{-3} \mathrm{seg}$. Assim o valor assintótico da partícula de ativação do canal de potássio dependente $\left(\mathrm{K}_{\mathrm{AHP}}\right)$ de cálcio é dada por:

$$
m_{\infty}=\frac{\left[\mathrm{Ca}^{+2}\right]}{\left[\mathrm{Ca}^{+2}\right]+0.00004}
$$


Dois canais não puderam ter as funções que descrevem o valor assintótico de suas partículas descritos por sigmóides. Os canais de cálcio de baixo limiar $\left(\mathrm{Ca}_{t}\right)$, potássio ativado por hiperpolarização $\left(K_{H}\right)$. Ao contrário do canal de cálcio de alto limiar que tem um limiar de ativação de $-0,040 \mathrm{~V}$ e é ativado quando ocorre um potencial de ação comum, o canal de cálcio de baixo limiar tem um limiar de ativação inferior ao limiar de disparo de um potencial de ação comum que é de $-0,055 \mathrm{~V}$; seu limiar de ativação é inferior a $-0,065 \mathrm{~V}$. Este canal é, portanto, ativado por correntes hiperpolarizadoras. Outra característica importante deste canal é que ele é inativado por despolarização prolongada. Através da ativação e inativação deste canal, os neurônios podem gerar disparos lentos que, devido a sua longa duração, terminam por ativar os canais de sódio e potássio e gerar potenciais de ação de alta frequência.

O canal de cálcio de baixo limiar $\left(C a_{t}\right)$ foi modelado de acordo com as seguintes expressões:

$$
\begin{aligned}
m_{\infty}(V) & =\frac{1}{1+e^{-\left(V(t)+60.5 \times 10^{-3}\right) / 6.2 \times 10^{-3}}} \\
h_{\infty}(V) & =\frac{1}{1+e^{\left(V(t)+84 \times 10^{-3}\right) / 4 \times 10^{-3}}} \\
\tau_{m}(V) & =\frac{0.181}{e^{-\left(V(t)+132 \times 10^{-3}\right) / 16.7 \times 10^{-3}}+e^{\left(V(t)+16.8 \times 10^{-3}\right) / 18.2 \times 10^{-3}}}+0.111 \times 10^{-3} \\
\text { se } \mathrm{V}<-80 \times 10^{-3} \mathrm{~V} & \\
\tau_{h}(V) & =0.294 e^{\left(V(t)+467 \times 10^{-3}\right) / 66.6 \times 10^{-3}} \\
\text { se } \mathrm{V} \geqslant-81 \times 10^{-3} \mathrm{~V} & \\
\tau_{h}(V) & =0.294 e^{-\left(V(t)+22 \times 10^{-3}\right) / 10.5 \times 10^{-3}}+28 \times 10^{-3}
\end{aligned}
$$

O canal de potássio ativado por hiperpolarização $\left(K_{H}\right)$ foi modelado de acordo com as seguintes expressões:

$$
\begin{aligned}
& m_{\infty}(V)=\frac{1}{1+e^{\left(V(t)+75 \times 10^{-3}\right) / 5.5 \times 10^{-3}}} \\
& \tau_{m}(V)=\frac{0.227}{e^{\left(-0.086 V(t)-14.59 \times 10^{-3}\right)}+e^{\left(0.0701 V(t)+1.87 \times 10^{-3}\right)}}
\end{aligned}
$$

\section{Canais Sinápticos.}

Foram implementados três modelos de canais sinápticos: AMPA, NMDA e GABA. A distribuição destes canais nos compartimento está descrita no Capítulo III - O Modelo. A abertura de canais sinápticos é modelada por uma mudança na condutância sináptica dependente do tempo $\left(g_{\sin }(t)\right)$. Esta condutância está em série com uma bateria $E_{\text {sin }}$ que gera o potencial e movimenta os íons envolvidos na ativação do canal.

$$
I_{\sin }(t)=g_{\sin }(t)\left(V(t)-E_{\sin }\right)
$$

A variação da condutância é comumente aproximada por uma função suave conhecida como função alfa. 


$$
g_{\text {sin }}(t)=g_{\max } \frac{t}{\tau_{1}} e^{\left(1-\frac{t}{\tau_{1}}\right)}
$$

Esta função aumenta rapidamente para o seu valor máximo $g_{\max }$. Em seguida decai mais vagarosamente para zero. No caso descrito acima, a condutância é determinada por dois parâmetros $g_{\max }$ e $\tau_{l}$. Sinapses lentas terão $\tau_{l}$ maiores e sinapses mais fortes terão $g_{\max }$ maiores. O GENESIS utiliza para a implementação de sinapses uma função mais geral,

$$
g_{\text {sin }}(t)=\frac{A g_{\max }}{\left(\tau_{1}-\tau_{2}\right)}\left(e^{\left(\frac{-t}{\tau_{1}}\right)}-e^{\left(\frac{-t}{\tau_{2}}\right)}\right), \text { para } \tau_{1}>\tau_{2},
$$

onde $A$ é uma constante de normalização que garante que $g_{\sin }$ alcance o valor máximo igual $g_{\text {max }}$. Há casos em que $\tau_{l}$ é diferente de $\tau_{2}$ e em decorrência disto é utilizada uma forma de exponencial dupla. Quando $\tau_{l}$ é igual a $\tau_{2}$, a função alfa é utilizada (BOWER \& BEEMAN, 1997).

O receptor NMDA foi modelado utilizando uma estratégia diferente. Em vista do fato de que a variação na condutância do NMDA é dependente da voltagem, a expressão utilizada foi:

$$
g_{\sin }(t)=\frac{g_{\max }\left(e^{\left(\frac{-t}{\tau_{1}}\right)}-e^{\left(\frac{-t}{\tau_{2}}\right)}\right)}{1+n\left[M g^{+2}\right] e^{-\gamma V(t)}},
$$

onde $n$ é $0,33 \mathrm{mM}^{-1},\left[\mathrm{Mg}^{+2}\right]$ é 1 e $\gamma$ é $0,06 \times 10^{-3} \mathrm{~V}^{-1}$. Todos os parâmetros foram retirados da literatura (ZADOR et al., 1990).

Tab. 9. Parâmetros utilizados na modelação dos canais sinápticos.

\begin{tabular}{l|l|l|l|l}
\hline \multicolumn{1}{c|}{ SINAPSE } & \multicolumn{1}{c|}{$\boldsymbol{g}_{\text {max }}$} & \multicolumn{1}{c|}{$\tau_{1}$} & \multicolumn{1}{c}{$\tau_{2}$} & \multicolumn{1}{c}{ Referência } \\
\hline$A M P A$ & $50 \times 10^{-9} \mathrm{~S}$. & $1 \times 10^{-3} \mathrm{seg.}$ & $1 \times 10^{-3} \mathrm{seg}$. & (PONGRACZ et al., 1992) \\
\hline$G A B A$ & $12,5 \times 10^{-9} \mathrm{~S}$. & $100 \times 10^{-3} \mathrm{seg}$. & $2 \times 10^{-3} \mathrm{seg}$. & (PONGRACZ et al., 1992) \\
\hline$N M D A$ & $2 \times 10^{-9} \mathrm{~S}$. & $80 \times 10^{-3} \mathrm{seg}$. & $0,66 \times 10^{-3} \mathrm{seg}$. & (ZADOR et al., 1990) \\
\hline
\end{tabular}




\section{Apêndice II.}

Padrão de Estimulação do sistema.

Como foi descrito no Capítulo III - O Modelo, a retina corresponde a uma camada bidimensional de células ganglionares de primatas da classe neurônios de ativação central (ONCenter) com propriedades funcionais $M$ que se projetam para as lâminas mais ventrais do NGL (lâminas 1 e 2) que, por sua vez, enviam os sinais do olho contralateral e ipsilateral para o córtex visual primário.

A resposta das células ganglionares individuais foi construída adotando-se um modelo que têm sido frequentemente usado para a modelação da resposta de neurônios do canal $\mathrm{X}$ da retina de gatos (SOMERS et al. 1995). Em vista das aproximações entre este canal e o canal M de primatas, o mesmo formalismo foi adotado neste caso (SHAPLEY \& PERRY, 1986). Os campos receptivos espaciais podem ser descritos através de um filtro em que as sub-regiões centrais e marginais são definidas como gaussianas bidimenssionais que são subtraídas uma da outra para descrever a relação antagônica entre estas sub-regiões. Este filtro é chamado de diferença de gaussianas.

A resposta do centro é dada por:

$$
G_{c}(x, y)=\frac{K_{c}}{2 \pi \sigma_{c}^{2}} e^{-\frac{x^{2}+y^{2}}{2 \sigma_{c}^{2}}}
$$

A resposta da margem é dada por:

$$
G_{m}(x, y)=\frac{K_{m}}{2 \pi \sigma_{m}^{2}} e^{-\frac{x^{2}+y^{2}}{2 \sigma_{m}^{2}}}
$$

Para gatos os valores adotados comumente são $\sigma_{\mathrm{c}}=10,6^{\prime}, \sigma_{\mathrm{m}}=31,8^{\prime}$ e a relação $\mathrm{K}_{\mathrm{c}} / \mathrm{K}_{\mathrm{m}}=17 / 16$. Neste trabalho adotou-se $\sigma_{\mathrm{c}}=5,0^{\prime}, \sigma_{\mathrm{m}}=11,5^{\prime} \mathrm{em}$ vista das diferenças entre os tamanhos dos campos receptivos de primatas e gatos (SHAPLEY \& PERRY, 1986).

Os campos receptivos temporais, por sua vez, podem ser descrito por funções exponenciais. Entretanto, os valores apresentados na literatura promoviam decaimentos muito rápidos e com isto um aspecto mais transiente do que aquele registrado em trabalhos experimentais. Em vista disso, utilizou-se apenas os perfis espaciais na descrição deste modelo.

As respostas das componentes central e marginal do filtro que compõe o campo receptivo das células ganglionares a um estímulo luminoso $(I(x, y))$ pode ser computada pelas convoluções:

$$
\begin{aligned}
& R_{c}(x, y)=\int_{-\infty}^{+\infty} \int_{-\infty}^{+\infty} G_{c}\left(x^{\prime}, y^{\prime}\right) I\left(x^{\prime}, y^{\prime}\right) d x^{\prime} d y^{\prime} \\
& R_{m}(x, y)=\int_{-\infty}^{+\infty} \int_{-\infty}^{+\infty} G_{m}\left(x^{\prime}, y^{\prime}\right) I\left(x^{\prime}, y^{\prime}\right) d x^{\prime} d y^{\prime}
\end{aligned}
$$

Com a resposta das células ganglionares dada por: 


$$
F(x, y)=R_{c}(x, y)-R_{m}(x, y)
$$

Por razões de economia computacional, o filtro diferença de gaussianas foi integrado apenas dentro dos limites de $2 \sigma_{m}$. $\mathrm{O}$ valor $F(x, y)$ para x e y constantes é também constante no tempo. Este valor contínuo precisa ser convertido em potenciais de ação. Assumindo que a ocorrência de um potencial de ação obedece a uma distribuição de Poisson, a probabilidade de que uma célula ganglionar dispare um potencial de ação no intervalo de tempo entre $\mathrm{t}$ e $\mathrm{t}+\Delta \mathrm{t}\left(\Delta \mathrm{t}=5 \times 10^{-5}\right)$ é dada por:

$$
p_{x, y}=\Delta t F(x, y)
$$

O sistema modelado foi submetido a um padrão de estimulação conhecido como grade sinusoidal que varia no espaço e pode ser descrito de acordo com:

$$
I(x, y)=A \cos (K x \cos \Theta+K y \sin \Theta-\Phi),
$$

onde $K$ é a frequência espacial da grade em ciclos por grau, $\Theta$ é a sua orientação em radianos, $\Phi$ é a sua fase espacial e $A$, amplitude do contraste (determinado como um valor adimensional que representa a diferença entre o ponto mais iluminado e o menos iluminado da grade). Para todas as simulações em que esta grade foi utilizada os valores de $K, \Phi$, foram mantidos iguais a 3,5 e 1,0. A orientação $(\Theta)$ e a amplitude do contraste $(A)$ foram variadas de acordo com a descrição no texto (Capítulo IV - Resultados).

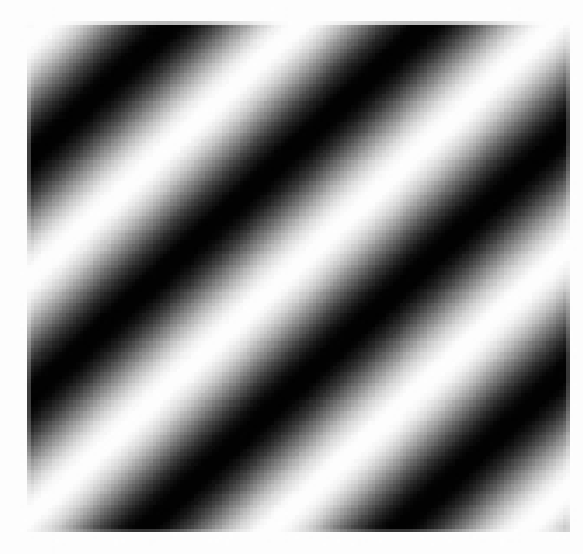

Figura 29. Exemplo de grade sinusoidal com $45^{\circ}$ de orientação. Este padrão de estimulação foi utilizado para investigar a seletividade de neurônios corticais à orientação. 


\section{Referências Bibliográficas.}

AZOUZ, R.; GRAY, C. M.; NOWAK, L. G.; McCORMICK, D. A. Physiological properties of inhibitory interneurons in cat striate cortex. Cerebral Cortex, v.7, n.6, p.534-545, 1997.

BARLOW, H. B.; MOLLON, J. D. The senses. 5.ed. New York, CAMBRIDGE, 1989.

BERNANDER, O.; DOUGLAS, R. J; MARTIN K. A. C.; KOCH, C. Synaptic background activity influences spatiotemporal integration in single pyramidal cells. Proc. Nat. Acad. Sci., v.88, n.24, p.11569-11573, 1991.

BLASDEL, G. G. Orientation selectivity, preference, and continuity in monkey striate cortex. Journal of Neuroscience, v.12, n.8, p.3139-3161, 1992.

BLASDEL, G. G.; FITZPATRICK, D. Physiological organization of layer 4 in macaque striate cortex. Journal of Neuroscience, v.4, n.3, p.880-895, 1984.

BLASDEL, G. G.; LUND, J.S. Termination of afferent axons in macaque striate cortex. Journal of Neuroscience, v.3, n.7, p.1389-1413, 1983.

BLASDEL, G. G.; SALAMA, G. Voltage-sensitive dyes reveal a modular organization in monkey striate cortex. Nature, v.321, n.6070, p.579-585, 1986.

BLOOMFIELD S. A.; HAMOS J. E.; SHERMAN, S. M. Passive cable properties and morphological correlates of neurons in the lateral geniculate nucleus of the cat. Journal of Physiology, v.383, n.Feb, p.653-692, 1987.

BOLZ, J.; GILBERT, C.D.; WIESEL, T. N. Pharmacological analysis of cortical circuitry. Trends in Neurosciences, v.12, n.8, p.292-296, 1989.

BOWER, J.; BEEMAN, D. The book of GENESIS: exploring realistic neural networks with the GEneral NEural SImulator System. 2.ed. Santa Clara, TELOS, 1997.

BUSH, P; SEJNOWSKI, T. Reduced compartmental models of neocortical pyramidal cells. Journal of Neuroscience Methods, v.46, n.2, p.159-166, 1993.

CALLAWAY, E. M. Local circuits in primary visual cortex of the macaque monkey. Annual Reviews of Neuroscience, v.21, n.1, p.47-74, 1998.

CHANGEUX, J-P. O homem Neuronal. 2.ed. Lisboa, DOM QUIXOTE, 1991.

CONNORS, B. W.; GUTNICK, M. J. Intrinsic firing properties of diverse neocortical neurons. Trends in Neurosciences, v.13, n.3, p.99-104, 1990.

CONNORS, B. W.; GUTNICK, M. J.; PRINCE, D. A. Electrophysiological properties of neocortical neurons in vitro. Journal of Neurophysiology, v.48, n.6, p.1302-1320, 1982.

DAS, A. Orientation in visual cortex: a simple mechanism emerges. Neuron, v.16, n.3, p.477-480, 1996.

DESCHÊNES, M.; PARADIS, M.; ROY, J. P.; STERIADE, M. Electrophysiology of neurons of lateral thalamic nuclei. Journal of Neurophysiology, v.51, n.6, p.1196-1219, 1984.

DOUGLAS, R.; MARTIN, K. Neocortex. In: SHEPHERD, G. M., (Ed.). The synaptic organization of the brain. New York, OXFORD UNIVERSITY PRESS, 1998. cap. 12, p.459-509.

ERISIR, A.; LAU, D.; RUDY, B.; LEONARD, C. S. Function of specific K+ channels in sustained high-frequency firing of fast-spiking neocortical interneurons. Journal of Neurophysiology, v.84, n.1, p.2476-2489, 1999. 
FERSTER, D. Orientation selectivity of synaptic potentials in neurons of cat primary visual cortex. Journal of Neuroscience, v.6, n.5, p.1284-1301, 1986.

FERSTER, D.; KOCH, C. Neuronal connections underlying orientation selectivity in cat visual cortex. Trends in Neurosciences, v.10, n.12, p.487-492, 1987.

FERSTER, D.; MILER K. D. Neural mechanisms of orientation selectivity in the visual cortex. Annual Reviews of Neuroscience, v.23, n.1, p.441-471, 2000.

FERSTER D.; CHUNG, S.; WHEAT, H. Orientation selectivity of thalamic input to simple cells of cat visual cortex. Nature, v.380, n.6571, p.249-252, 1996.

FITZPATRICK, D. Cortical imaging: Capturing the moment. Current Biology, v.10, n.5, p.R187R190, 2000.

FITZPATRICK, D.; LUND, J. S.; SCHMECHEL, D. E.; TOWELS, A. C. Distribution of GABAergic neurons and axon terminals in the macaque striate cortex. Journal of Comparative Neurology, v.264, n.1, p.73-91, 1987.

GOODHILL, G. J. The influence of neural activity and intracortical connectivity on the periodicity of ocular dominance stripes. Network: Computation in Neural Systems, v.9, n.3, p.419-432, 1998.

HARTLINE, H. K. The response of single optic nerve fibers of the vertebrate eye to illumination of the retina. American Journal of Physiology, v.130, n.Feb., p.690-699, 1938.

HODGKIN, A. L.; HUXLEY, A. F. A quantitative description of membrane current and its application to conduction and excitation in nerve. Journal of Physiology, v.117, n.4, p.500544, 1952.

HORTON, J. C.; HOCKING, R. D. Intrinsic variability of ocular dominance column periodicity in normal macaque monkeys. Journal of Neuroscience, v.16, n.22, p.7228-7339, 1996.

HUBEL, D. H. Eye, brain and vision. 1.ed. New York, Scientific American Library, 1987.

HUBEL, D. H.; WIESEL, T. N. Laminar and columnar distribution of geniculo-cortical fibers in the macaque monkey. Journal of Comparative Neurology, v.146, n.4, p.421-450, 1972.

HUBEL, D. H.; WIESEL, T. N. Functional architecture of macaque monkey visual cortex. Proc. R. Soc. Lond. B., v.198, n.1130 1-\&, p.1-59, 1977.

HUBEL, D. H.; WIESEL, T. N. Receptive fields and functional architecture of monkey striate cortex. Journal of Physiology London, v.195, n.1, p.215-243, 1968.

HUBEL, D. H.; WIESEL, T. N. Receptive fields, binocular interaction and functional architecture in the cat's visual cortex. Journal of Physiology London, v.160, n.1, p.106-154, 1962.

HUBEL D. H.; FREEMAN, D. C. Projection into visual-field of ocular dominance columns in macaque monkey. Brain Research, v.122, n.2, p.336-343, 1977.

HUGENARD, J. R.; McCORMICK, D. A. Simulation of the currents involved in rhythmic oscilations in thalamic relay neurons. Journal of Neurophysiology, v.68, n.4, p.1373-1383, 1992.

JONES, E. Viewpoint: The core and matrix of thalamic organization. Neuroscience, v.85, n.2, p.331-345, 1998.

JONES, E. G.; HENDRY, S. H. Basket cells. In: PETERS, A.; JONES, E. G., (Eds.). Cerebral Cortex Volume 1. New York and London, Plenum Press, 1984. cap. 8, P.309-336.

KANDEL, E. R.; SCHWARTZ, J. H.; JESSEL, T. M. Principles of neural science. 3.ed. Norwalk, Connecticut, Appleton \& Lange, 1991. 
KISVÁRDAY, Z. F.; TÓTH, E.; RAUSCH, M.; EYSEL, U. T. Orientation-specific relationship between populations of excitatory and inhibitory lateral connections in the visual cortex of the cat. Cerebral Cortex, v.7, n.7, p.605-618, 1997.

$\mathrm{KOCH}, \mathrm{C}$. Biophysics of Computation: information processing in single neurons. 1.ed. New York, OXFORD UNIVERSITY PRESS, 1998.

KOCH, C.; SEGEV, I. Methods in neural modeling. 1.ed. Cambridge, MITPress, 1989.

KUFFLER,S. W. Discharge patterns and functional organization of the mammalian retina. Journal of Neurophysiology, v.16, n.1, p.37-68, 1953.

LUND, J. S. Spiny stellate neurons. In: PETERS, A.; JONES, E. G., (Eds.). Cerebral Cortex Volume 1. New York and London, Plenum Press, 1984. cap. 7, p.255-308.

LUND, J S.; BOOTHE, R. G. Interlaminar connections and pyramidal neuron organization in the visual cortex, area 17, of the macaque monkey. Journal of Comparative Neurology, v.159, n.3, p.305-334, 1975.

MALACH, R.; AMIR, Y.; HAREL, M.; GRINVALD, A. Relationship between intrinsic connections and functional architecture revealed by optical imaging and in vivo targeted biocytin injections in primate striate cortex. Proc. Nat. Acad. Sci., v.90, n.22, p.10469-10473, 1993.

MALPELI, J. G.; LEE, D.; BAKER, F.H. Laminar and retinotopic organization of the macaque lateral geniculate nucleus: magnocellular and parvocellular magnification functions. Journal of Comparative Neurology, v.357, n.3, p.363-377, 1996.

McCORMICK, D. A.; CONNORS, B. W.; LIGHTHALL, J. W Comparative electrophysiology of pyramidal and sparsely spiny stellate neurons of the neocortex. Journal of Neurophysiology, v.54, n.4, p.782-806, 1985.

McCORMICK, D. A.; HUGENARD, J. R. A model of the eletrophysiological properties of thalmocortical relay neurons. Journal of Neurophysiology, v.68, n.4, p.1384-1400, 1992.

McCORMICK, D. A; FEESER, H. R. Functional implications of burst firing and single spike activity in lateral geniculate relay neurons. Neuroscience, v.39, n.1, p.103-113, 1990.

MOUNTCASTLE, V. B. The columnar organization of the neocortex. Brain, v.120, n.4, p.701-722, 1997.

NEHER, E.; SACKMANN, B. Single-channel currents recorded form membrane frog muscle fibers. Nature, v.260, n.5554, p.799-802, 1976.

O'KUSKY, J.; COLONIER, M. A laminar analysis of the number of neurons, glia and synapses in the visual cortex (area 17) of adult macaque monkeys. Journal of Comparative Neurology, v.210, n.3, p.278-290, 1982.

PETERS, A The organization of the primary visual cortex in the macaque. In: PETERS, A.; ROCKLAND, S. K. (Eds.). Cerebral Cortex Volume 10. New York and London, Plenum Press, 1997. cap. 1, p.1-34.

PETERS, A.; PAYNE, B. R.; BUDD, J. A Numerical analysis of the geniculcortical input to striate cortex in the monkey. Cerebral Cortex, v.4, n.3, p.215-219, 1994.

PONGRACZ, F.; POOLOS, N. P.; KOCSIS, J.D.; SHEPHERD, G. M. A model of NMDA receptor-mediated activity in dendrites of hipocampal CA1 pyramidal neurons. Journal of Neurophysiology, v.68, n.6, p.2248-2259, 1992.

RALL, W.; BURKE, R. E.; HOLMES, W.; JACK, J. B.; REDMAN, S. J.; SEGEV, I. Matching dendritic neuron models to experimental data. Physilogical Reviews, v.72, n.4, p.159-189, 1992. 
RINGACH, D.; HAWKEN, M. J.; SHAPLEY, R. Dynamics of oientation tuning in macaque primary visual cortex. Nature, v.387, n.6630, p.281-284, 1997.

ROCKEL, A. J.; HIORNS, R. W.; POWEL, T. P. S. The basic uniformity in structure of the neocortex. Brain, v.103, n.Jun, p.221-244, 1980.

RODIECK, R. W. The primate retina. Comparative Primate Biology, v.4, n.1, p.203-278, 1988.

ROSIER, A. M.; ARCKENS, L.; ORBAN, G. A.; VANDESANDE, F. Laminar distribution of NMDA receptors in cat and monkey visual cortex visualized by [3H]-MK-801 binding. Journal of Comparative Neurology, v.355, n.3, p.369-380, 1993.

SCHEIN, S.J.; MONASTERIO, F. M. Mapping of retinal and geniculate neurons onto striate cortex of macaque monkey. Journal of Neuroscience, v.7, n.4, p.996-1009, 1987.

SCHILLER, P. H.; MALPELI, J. G. Functional specificity of lateral geniculate nucleus laminae of rhesus monkey. Journal of Neurophysiology, v.41, n.3, p.788-797, 1978.

SCHILLER, P. H.; SANDELL, J. H.; MAUNSELL, J. H. R. Functions of ON and OFF channels of the visual system. Nature, v.322, n.6082, p.824-825, 1986.

SEGEV, I. Dendritic processing. In: ARBIB, M. A. (Ed.). The handbook o brain theory and neural networks. Cambridge, MITPress, 1995. cap. 25, p.282-289.

SHAPLEY, R.; PERRY, H. Cat and monkey retinal ganglion cells and their visual functional roles. Trends in Neurosciences, v.9, n.5, p.229-235, 1986.

SHERMAN, M. S.; KOCH, C. Thalamus. In: SHEPHERD, G. M., (Ed.). The synaptic organization of the brain. New York, OXFORD UNIVERSITY PRESS, 1998. cap. 8, p.289328.

SHERMAN, M. S.; KOCH, C. The control of retinogeniculate transmission in the mammalian lateral geniculate nucleus. Experimental Brain Research, v.63, n.1, p.1-20, 1986.

SHERMAN, S. M.; GUILLERY, R. W. Functional organization of thalamocortical relays. Journal of Neurophysiology, v.76, n.3, p.1367-1395, 1996.

SOMERS, D. C.; NELSON, S. B.; SUR, M. Emergent model of orientation selectivity in cat visual cortical simple cells. Journal of Neuroscience, v.15, n.8, p.5448-5465, 1995.

STERLING, P. Retina. In: SHEPHERD, G. M., (Ed.). The synaptic organization of the brain. New York, OXFORD UNIVERSITY PRESS, 1998. cap. 6, p.205-253.

SWINDALE, N. V. Cortical organization: modules, polymaps and mosaics. Current Biology, v.8, n.8, p.R270-R273, 1998.

TOOTELL, R. B.; SWITKES, E.; SILVERMAN, M. S.; HAMILTON, S. L. Functional anatomy of macaque striate cortex. II. retinotopic organization. Journal of Neuroscience, v.8, n.5, p.1531$1568,1988$.

VAN ESSEN, D.C.; NEWSOME, W. T.; MAUNSELL, J. H. R. The visual-field representation in striate cortex of the macaque monkey - asimetries, anisotropies, and individual variability. Vision Research, v.24, n.5, p.429-448, 1984.

WÄSSLE, H.; GRÜNERT, U.; RÖHRENBECK, J.; BOYCOTT, B. B. Retinal ganglion cell density and cortical magnification factor in the primate. Vision Research, v.30, n.11, p.1897-1911, 1990.

WÄSSLE, H.; GRÜNERT, U.; RÖHRENBECK, J.; BOYCOTT, B. B. Cortical magnification factor and the ganglion cell density of the primate retina. Nature, v.341, n.6243, p.643-646, 1989. 
WEHMEIER, U.; DON, D.; KOCH, C.; VAN ESSEN, D. Modeling the mammalian visual system. In: KOCH, C.; SEGEV, I. (Eds.). Methods in neural modeling. Cambridge, MITPress, 1989. cap. 10, p.335-359.

WELIKY, M.; KANDLER, K.; FITZPATRIK, D.; KATZ, L. C. Patterns of excitation and inhibition evoked by horizontal connections in visual cortex share a common relationship to orientation columns. Neuron, v.15, n.3, p.541-552, 1995.

WU, C. W-H.; FLORENCE, S. L.; TIGGES, M. H.; KAAS, J. H. Morphology of M-cell axon arbors in striate cortex of monkeys reared with monocular aphakia. Developmental Brain Research, v.108, n.1, p.47-57, 1998.

YABUTA, N. H.; CALLAWAY, E. M. Functional streams and local connections of layer 4C neurons in primary visual cortex of the macaque monkey. Journal of Neuroscience, v.18, n.22, p.9489-9499, 1998.

ZADOR, A.; KOCH, C.; BROWN, T. H. Biophysical model of hebbian synapse. Proc. Nat. Acad. Sci., v.87, n.17, p.6718-6722, 1990.

ZHAN, X. J.; COX, C. L.; RINZEL, J.; SHERMAN, S. M. Current clamp and modeling studies of low-threshold calcium spikes in cells of the cat's lateral geniculate nucleus. Journal of Neurophysiology, v.81, n.5, p.2360-2373, 1999. 